TÜRÜK

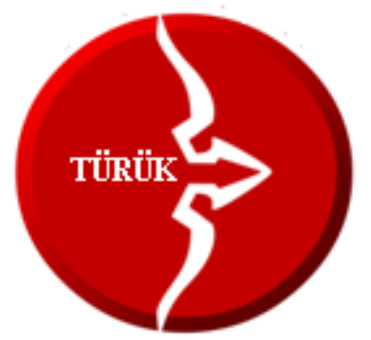

Uluslararası Dil, Edebiyat

ve Halkbilimi Araştırmaları Dergisi

2016 Yıl:4, Sayı:8

Sayfa:93-144

ISSN: $2147-8872$

\title{
BARTIN YÖRESİ KIRSAL YERLEŞMELERİNDE AİLE YAPISI VE YAŞAM KÜLTÜRÜNÜN HALK MIMMARISİNE ETKISİ
}

Mahmut Davulcu*

\begin{abstract}
Özet
Halk mimarisi, yaratıcısı olan halkın ihtiyaçlarına göre şekillenip biçimlenen, toplumun yaşam tarzını, ilişkilerini, üretim ve tüketim biçimlerini, inanış ve geleneklerini en yalın biçimde ortaya koyan kültürel bir olgudur. Endüstri devrimi, modernleşme ve hızlı toplumsal değişim, her alanda olduğu gibi mimarlık konusunda da köklü değişiklikler yaşanmasına neden olmuş, inşaat teknolojisi ve malzemelerinde büyük yenilikler meydana getirmiştir. Bununla birlikte özellikle kırsal kesimde halk mimarisi ve geleneksel mimarlık bilgisi kısmen de olsa yaşatılmaktadır. Somut Olmayan Kültürel Mirasımızın bir parçasını oluşturan halk mimarimizi korumak ve gelecek nesillere aktarmak hem toplumsal bir görev hem de kültürel bir gerekliliktir. Korumanın ilk adımı ise tespit çalışmaları yani halk mimarisi ile ilgili araştırmaların yapılmasıdır. Yörede farklı tarihlerde gerçekleştirilen çalışmalar neticesinde İl genelinde mimari geleneklerin terk edilmeye başlandığı, halk mimarisi ürünlerinin ise hızla yok olmaya yüz tuttuğu hatta bazı bölgelerde tamamen yok edildiği gözlemlenmiştir. Bu gelişmelerin en büyük nedeni modern yapı teknik ve malzemelerinin yörede yaygınlaşması, geleneksel hayat tarzının nihayete ermesi, insanların değişen beğeni ve arzuları ile aile yapısındaki değişimlerdir.Hazırlanan bu çalışmada Türkiye'nin Batı Karadeniz Bölgesinde yer alan ve yoğun orman örtüsüyle dikkati çeken Bartın yöresi halk mimarisi 2001, 2002, 2009 ve 2010 yıllarında gerçekleştirilen alan çalışması ve incelemelerde elde edilen bilgi, belge ve veriler 1şığında, halkbilimsel bir bakış açısı ile incelenmiş, kırsal yerleşmelerde mevcut halk mimarisinin tasviri yapılmış, son olarak da değişen aile yapısı ile yaşam kültürünün kırsal mimari üzerindeki etkileri sorgulanmıştır.
\end{abstract}

Anahtar Kelimeler: Bartın, aile, halk mimarisi, kırsal mimari, somut olmayan kültürel miras.

- Folklor Araştırmacısı, Kültür ve Turizm Bakanlığı, Antalya, efuzade@gmail.com 


\title{
THE FOLK ARCHITECTURE IN THE RURAL SETTLEMENTS OF BARTIN
}

\begin{abstract}
Folk architecture is a cultural pheomenon which is shaped according to needs of the folk, who creates it, and presents the lifestyle, social relationships, types of production and consumption, beliefs and traditions of the society in the plainest way. As in every are, the industrial revolution and rapid social change also led to radical changes in the field of architecture and created major innovations in building technology and materials. Besides, folk architecture and vernacular architecture knowledge are, although partly, maintained especially in rural areas. It is both a social task and a cultural neccesity to conserve and hand down to next generations our folk architecture which forms a part of our abstract cultural heritage. The first step of conservation is to carry out evaluation Works, in other words, researches on folk architecture. Prepared area, this article of Turkey's western Black Sea region and attracts attention with its dense forest cover Bart local rural architecture in 2001, 2002, 2009 and 2010 information obtained in a field study and review in the light of the documents and data were analyzed with folkloristic perspective. In the region as a result of work carried out at different dates throughout the province of architectural traditions that began to be abandoned, while the folk architecture of the product is bound to be rapidly disappearing completely destroyed it was observed even in some areas. The biggest reason for the traditional architecture of the largely wooden, so it is based on forest products and building laws in force in the wood should be limited but can be used. According to the concrete jungle of the region's rich timber to be cheaper and easier it is available unfortunately can not provide. This fall in the end of the traditional lifestyle of the changing tastes of people with large families where the parents and desires in order to stop the kernel has been very effective.
\end{abstract}

Key Words: Bartın, folk architecture, rural architecture, tradition of mastership, intangible cultural heritage.

\section{Giriş}

Halk mimarisi, yaratıcısı olan halkın ihtiyaçlarına göre şekillenip biçimlenen, toplumun yaşam tarzını, ilişkilerini, üretim ve tüketim biçimlerini, inanış ve geleneklerini en yalın biçimde ortaya koyan kültürel bir olgudur. Endüstri devrimi, modernleşme ve hızlı toplumsal değişim, her alanda olduğu gibi mimarlık konusunda da köklü değişiklikler yaşanmasına neden olmuş, mekânsal organizasyon, inşaat teknolojisi ve malzemelerinde büyük yenilikler meydana getirmiştir. Halk mimarisinin değişimi konusunda günümüz aile yapısındaki dönüşümler de başat bir rol oynamış ve oynamaktadır. 
Elimizdeki bu çalışmanın çıkış noktasını kırsal yerleşme-kırsal mimari-halk mimarisiaile yapısı ilişkilerini Anadolu'nun kuzeybatısında, Batı Karadeniz bölgesinde yer alan ve doğal güzellikleri ile dikkat çeken Bartın ili örneğinde sorgulamak, değişen aile yapısının halk mimarisi üzerindeki etkilerini ortaya koymaktır.

\section{Araştırma Evreni ve Örneklem}

Küçük bir il olan Bartın 1991 yılında Zonguldak ilinden ayrılarak il statüsü kazanmıştır. Kuzeyinde Karadeniz'in bulunduğu İlin doğusunda Kastamonu, güneyinde Karabük, batısında ise Zonguldak illeri yer alır. İdari olarak dört ilçeye (Merkez, Ulus, Kurucaşile, Amasra) ve dört beldeye (Abdipaşa, Hasankad1, Kozcağız, Kumluca) ayrılmıştır. 265 köyün bağlı olduğu İlin toplam nüfusu, TÜİK verilerine göre 2014 yılı rakamları ile 189.405 kişidir ${ }^{1}$. Neredeyse tüm mevsimlerin ılıman ve yağışlı geçtiği İlin ekonomisi tarım, hayvancılık, balıkçılık ve bunun yanı sıra kısmen sanayiye (orman ürünleri) dayalıdır. Dağlar ve ormanlar İl toprakları üzerinde önemli bir yer tutar. Bölgenin yaklaşık \% 60'1 ormanlarla kaplıdır. Bitki ve ağaç türleri açısından son derece zengin bir yapı sergileyen orman varlığı, özellikle engebeli arazi ve yükseltilerde karşımıza çıkar.

Yörede gerçekleştirilen inceleme ve araştırma gezilerinin amacı kaybolmakta ve değişmekte olan mevcut mimari bilginin ve "halk mimarisi" geleneğinin tespiti, belgelenmesi, derlenmesi ve arşivlenmesidir. Çalışmalar geleneksel dokusunu muhafaza etmiş olan ve temsil yeteneği olduğu düşünülen yerleşim merkezlerinde gerçekleştirilmiştir ${ }^{2}$.

\section{Veri Toplama ve Analiz Tekniği}

İlde 2001, 2002, 2009 ve 2010 yıllarında gerçekleştirilen saha araştırmaları sırasında uygulanan araştırma tekniği halkbilime özgü olan gözlem ve görüşme teknikleridir. Kaynak kişiler bilhassa icra ve taşıyıcılık vasfına sahip olan yapı ustalarından seçilmiş, ev içi yaşam konusunda ise kadınlarla görüşme yapılmıştır. Kaynak kişiler ile gerçekleştirilen görüşmeler ses kayıt cihazı ve yazarak derleme metodu ile kayıt altına alınmıştır. Bu makale, söz konusu çalışmalarda elde edilen materyal ve bilgilerin mevcut literatür ve arşiv belgeleri 1şı ğında analiz edilerek değerlendirilmesi yoluyla kaleme alınmıştır.

Çalışma kapsamında yöreye has halk mimarlığının kültürel ve geleneksel boyutuyla tasviri yapılacak, bu mimarlığın oluşumu, değişimi ve dönüşümü üzerinde aile ve yaşam kültürünün etkisi irdelenecektir.

Makalenin hazırlanması amacıyla kullanılan tüm görsel ve sözlü kaynaklar Kültür ve Turizm Bakanlığı Halk Kültürü Bilgi ve Belge Merkezi’ne aittir.

\footnotetext{
${ }^{1}$ http://www.bartin.gov.tr

${ }^{2}$ Bölgede çalışma yapılan yerleşimler: Bartın İli Merkez, Bartın İli Merkez Uğurlar Köyü, Merkez Kozcağız Beldesi, Merkez Kozcağız Beldesi, Mamak Köyü, Merkez Kozcağız Beldesi Özbaşı Köyü, Ulus İlçesi Merkez, Ulus İlçesi Eldeş Köyü, Ulus İlçesi Aşağıçerçi Köyü, Ulus İlçesi Yukarıdere Köyü, Ulus İlçesi Şirinler Köyü, Ulus İlçesi Ulukaya Köyü, Ulus İlçesi Kalecik Köyü, Ulus İlçesi Kumluca Beldesi Merkez, Ulus İlçesi Kumluca Beldesi Zafer Köyü, Amasra İlçesi, Merkez, Amasra İlçesi Tarlaağzı Köyü, Kurucaşile İlçesi Merkez, Kurucaşile İlçesi Ovatekkeönü Köyü, Kurucaşile İlçesi Kömeç Köyü, Kurucaşile İlçesi Uğurlu Köyü, Kurucaşile İlçesi Kapısuyu Köyü, Kurucaşile İlçesi Şeyhler Köyü, Kurucaşile İlçesi Çayaltı Köyü.
} 


\section{Kavramsal Çerçeve: Aile, Halk Mimarisi, Kırsal Yerleşme, Kırsal Mimari}

\subsection{Aile}

Aile; insan türünün devamını sağlayan, toplumsallaşma sürecinin ilk ortaya çıktığı, toplumda oluşturulmuş maddi ve manevi zenginlikleri kuşaktan kuşağa aktaran, biyolojik, psikolojik, ekonomik, toplumsal, hukuksal, vb. yönleri bulunan toplumsal bir birimdir (Sayın, 1990:2). Toplumun temel taşı ve çekirdeği olan ailenin oluşumu ve yapısal özellikleri yaşam tarzı, sosyo-ekonomik durum, din gibi faktörlere göre değişebilmektedir. Toplumun temel kurumlarından birisi olan aile ülkenin toplumsal örgütlenmesinde önemli bir yer tutar (Kongar, 1970:58). Aile, bir kurum olarak toplumsal ve kültürel açıdan birçok işlevi yerine getirir. Ailevi ilişkiler toplumsal yapı ile gerek somut ve gerekse somut olmayan kültürün oluşumunda önemli ve temel argümanlardandır.

Günümüzde Türkiye'nin toplumsal yapısına hâkim olan aile tipi çekirdek ailedir. Bununla birlikte yakın zamanlara kadar özellikle kırsal bölgede yaygın olan aile tipinin geleneksel geniş aile olduğu bir vakıadır. 1950'li yıllarda başlayan ve 80'li yıllardan itibaren hızlanan kırsal dönüşüm ve şehirleşme süreci sonucunda aile yapısı ve işlevleri çeşitli açılardan etkilenmiş ve değişime uğramıştır. Anne, baba ve çocuklardan oluşan çekirdek aileden farklı olarak geleneksel geniş aile tipi, birkaç kuşağın bir arada yaşadığı, akrabalık ilişkilerinin son derece güçlü olduğu, günlük hayatın büyük ölçüde inanç, gelenek ve göreneklerle şekillendiği, aile ekonomisinin tarım ve hayvancılığa dayandığı, erkek egemenliğinin ve ataerkil yapının hakim olduğu aile tipidir. Geleneksel geniş ailede gelişmiş bir ekonomik işbirliği ve işbölümü vardır (Kongar, 1970:63). Üretim biçimi olarak tarım ve hayvancılığın ağırlıklı olduğu geleneksel yaşamda işin yoğunluğu işgücünün de yüksek olmasını ve kalabalık geleneksel geniş aile düzenini zaruri kılmıştır.

\subsection{Halk Mimarisi}

Endüstri Öncesi Dönemin (Tarım Çağı) kendisine has şartları içerisinde yaratılan ve 19. yüzyılda meydana gelen Endüstri Devrimiyle birlikte yok olmaya başlayan halk mimarisi; yaratıldığı çağın ve çevrenin sunduğu teknik, malzeme ve bilgi birikimi ile halkın ihtiyaçlarına göre şekillenip biçimlenen; yaratıcısı olan toplumun yaşam tarzını, toplumsal ilişkilerini, üretim ve tüketim biçimlerini, inanış ve geleneklerini en yalın biçimde ortaya koyan kültürel bir olgudur. Halk mimarisinin yaratıcısı, son derece basit el aletleri kullanan yerel yapı ustaları ile yapı sahiplerinin bizzat kendileridir. Akademik olarak tanımlanabilecek bir eğitim sisteminden ya da yazılı kaynaklardan beslenmeyen bu olgunun oluşumunda en önemli unsur olarak karşımıza çıkan yapı tecrübe ve bilgi birikimi babadan oğula usta-çırak ilişkisi içerisinde kuşaktan kuşağa aktarılmakta, bu da mimariye anonim bir çehre kazandırmaktadır. Estetik ve lüksten çok işlevsel kaygıların ve rasyonel çözümlerin ağır bastığı halk mimarisi; ev, ambar, samanlık, köyodası, çeşme, kuyu, türbe, değirmen, cami, mescit gibi anıtsallıktan uzak; yapılışları itibarıyla içerisinde yer aldığı iklim, coğrafya, ve doğa ile uyumlu, yapaylıktan uzak eserleri kapsamaktadır.

Herhangi bir mimari eserin halk mimarisi kategorisi içerisinde yer almasını sağlayan kıstas onun adı, tipi, büyüklüğü ya da fiziki olarak bulunduğu yer değildir. Kıstas, o yapıtın 
üretilmesi sürecine hakim olan felsefi düşünce ile yaratıcılarının dünyaya bakış açısıdır. Bundan dolayı halk mimarisi ürünleri merkezi idarenin ya da toplumun ortak eğilimlerinden kopuk elitist sınıfların otorite, güç, zenginlik ve ihtişamlarını simgeleyen; bir parça da olsa "ölümsüzlük iksirinden" pay almayı uman mimari yapıtlardan kesin olarak ayrılır. Endüstriye dayalı yapay malzemelerden ziyade yakın çevrede kolaylıkla ulaşılabilen doğal malzemelerin kullanılmasından dolayı (ormanlık alanlarda ahşap, volkanik bölgelerde taş, bozkırda çamur) ortaya çıkan ürünler de içerisinde yer aldıkları doğaya ve iklime uyumludur.

\subsection{Kırsal Yerleşme}

Ülkemizde kırsal yerleşme olarak tanımlanan yerleşmeler, kırsal alanlar üzerinde kurulu bulunan, nüfus yoğunluğu düşük, ekonomisi tarım, hayvancılık, ormancılık ve küçük zanaatlara dayalı olan, altyapısı ve fiziki imkanları zayıf, geleneksel değerlerin baskın olduğu, kendisine has bir sosyolojisi ve kültürel yapısı olan köy, yayla, bucak gibi yerleşmelerdir.

\subsection{Kırsal Mimari}

Kırsal mimari kırsal ailenin ve toplumun temel gereksinimlerini karşılamak amaciyla biçimlenmiş olan yapılar manzumesidir. Kırsal mimariyi, halk mimarisinin kırsal alanlardaki örnekleri olarak tanımlamak da mümkündür.

\section{Aile ve Yaşam Kültürünün Halk Mimarisi Üzerindeki Etkileri}

Mimari çevrenin oluşumu, gelişimi ve değişimi konusunda ailenin ve aile yapısı ile yaşam kültürünün etkileri son derece önemlidir. Aile yapısının mimari üzerindeki etkileri kent ortamına göre- kırsal çevrelerde daha güçlüdür. Kırsal bölgede mimari eserlerin tasarım ve inşa sürecine ailenin katılımının daha etkin ve yoğun olması bu durumu beraberinde getirmiştir. Özellikle konut mimarisinin şekillenmesi büyük ölçüde aile yapısı ile ilişkilidir. Aile faktörü ve aileye ilişkin özellikler (ailenin büyüklüğü, yaşam biçimi, dini inancı, meskeni kullanım şekilleri, sosyal ilişkileri, ekonomik durumu, üretim-tüketim ilişkileri, aileye ilişkin örf, adet, gelenek ve görenekler) özellikle konut mimarisinin şekillenmesinde çok önemli bir yer tutar. Farklı aile biçimleri ailenin iç ilişkilerini de değiştirerek konut mekânının biçimlenmesini etkilemektedir (Yeler, 2005:161). Aile yapısında meydana gelebilecek değişimler konut mimarisinde de karşılığını bulmakta bu değişimlere cevap verebilecek yenilikler ya da dönüşümler yaşanmaktadır. Bununla birlikte aile ve aile yapısının etkileri yalnızca konutlar üzerinde değil konutun eklentileri ve diğer yapılar üzerinde de müşahede edilebilmektedir.

Günümüzde geleneksel geniş aile tipi hızla çekirdek aileye dönüşmekte ve mimari yapılaşma ve uygulamalar da buna uygun bir şekilde gerçekleştirilmektedir. Buradan hareketle şehir mimarisinden esinlenilmiş ve örnek alınmış konutlar kırsal bölgeyi doldurmaktadır. Aile yapısındaki değişim konut içinde gelişen eylemlerin ve dolayısıyla bununla ilişkili mimari ayrıntıların da farklılaşmasına neden olmaktadır. 


\section{Bartın Yöresinde Yerleşme Özellikleri}

Dağlık ve engebeli arazi parçalarından oluşan Bartın ilinin topografik özellikleri kırsal bölgede düzenli ve toplu bir biçimde yerleşmeye elverişli değildir. Bu nedenle kırsal yerleşmelerde spontane olarak oluşan ve gelişen dağınık bir doku ve yerleşme biçimi söz konusudur. Köy ve bu köyleri oluşturan mahalleler yeterli düz arazi olmaması nedeniyle eğimli sırt, yamaç, eteklerle, vadi ve akarsu yataklarının keserek parçaladığı dağlık, ormanlık ve dalgalı bir arazi üzerinde kuruludur. Arazinin nispeten daha düz alçak kısımları özellikle yağışlı mevsimlerde (ilkbahar, sonbahar) sık sık yaşanan taşkınlar nedeniyle yerleşim yeri olarak kullanılmamıştır. Ancak bunun istisnaları da yok değildir. Bölge halkı yüksek bölgelerin düzlüklere tercih edilmesinin nedeni olarak, belki de tarihsel olaylardan dolayı, kendi can ve mal güvenliklerini öne sürmektedir.

Köyler, özellikle iç kesimlerdeki dağ köyleri, kendi içlerinde bir bütünlük göstermezler ve fiziki olarak birbirlerinden ayrı parçalardan (mahalleler) oluşur. Ayrı bir köy görünümündeki bu mahallelerde yaşayan halk genellikle birbirleri ile akrabalık ilişkisi içerisindedir. Köylerdeki mimari dokuyu oluşturan ev, ambar, samanlık gibi yapılar arazi üzerine rast gele serpiştirilmiştir, bazı yerlerde ise birkaç evlik gruplar söz konusudur. Hatta sokak dokusunun meydana geldiği alanlar bile mevcuttur ${ }^{3}$. Haneler ve mahalleler arasında iletişimi sağlayan toprak yollar (bu yolların çoğu eski patikaların, araçların geçebilmesine olanak verecek şekilde sonradan genişletilmesiyle oluşturulmuştur) ve patikalar topografyaya uygun bir şekilde, doğal çizgileri takip etmektedir. Her şeye rağmen bölgede karşılaştığımız dağınık yerleşme biçimi Doğu Karadeniz bölgesindeki kadar aşırı uçlara varmamıştır. Köyler ve mahalleler arasındaki sosyal, iktisadi ve insani ilişkiler geçmişte divan olarak nitelenen birkaç köy tarafından ortaklaşa kullanılan ve örneklerini Kuzeybatı Anadolu bölgesinde çokça görmeye alıştığımız Cuma camileri vasıtasıyla kurulmaya çalışılmıştır.

Köylerde mevcut geleneksel dokuyu oluşturan ana unsur doğal olarak evlerdir. Ambar, samanlık, karaltı gibi evle doğrudan ilintili yapılar kar yağışının hane halkını ve hayvanları etkilememesi için evin hemen yakınlarına inşa edilmiş, bir anlamda rasyonel bir ilişki kurulmuştur. Çeşme, mısır firını, mahalle odası gibi ortak kullanım alanları mahalle içerisinde her evin ulaşabileceği merkezi bölgelere yerleştirilmiştir. Arazisi müsait köylerin ortak bir harman yeri bulunmaktadır. Değirmenlerse, zaruri olarak, suyun en verimli ve en kolay bir biçimde kullanılabileceği akarsulara yakın alanlar üzerinde ve köy dışında karşımıza çıkar.

\section{Kırsal Yerleşmelerde Yapı Tipleri}

\subsection{Konut}

Halk mimarisi olgusu içerisinde incelenen yapı tipleri arasında konutun kendisine has bir yeri bulunmaktadır. Konut, insanların yaşam biçimini, davranış biçimlerini, çevresel tercihlerini, imgelerini, zaman-mekân ilişkilerini, kullanıcısının özeyle ilgili imgelerini, kendini kanıtlama ve anlatma eğilimini, tasarım, donatım ve biçemi ile bireyin kişilik ve ayrıcalığını belirten insan yaşamıyla kenetlenmiş bir olgudur (Gür, 2000:11). Konut, ailenin

${ }^{3}$ Kurucaşile ilçesi Çayaltı ve Kömeç köylerinde taş döşeli sokaklar tespit edilmiştir. 
koruyucu kabuğudur, ancak, daha da önemlisi, aile kimliğinin en çok ve en net temsil edildiği ve korunduğu sosyo-fiziksel bir mekan birimidir (Alga, 2005:23). Konut ve eklentileri ailenin yuva kurma, barınma, korunma, güvenlik, üretim gibi işlevlerini yerine getirmesine yardımcı olan fiziksel ortamlar olarak da düşünülebilir.

Kırsal bölgede yer alan geleneksel konutlar bazı ünik örnekler ${ }^{4}$ bir kenarda tutulacak olursa genellikle iki kat olarak tasarlanıp inşa edilmiş mimari yapıtlardır. Kat sayısı ikiyi aşan yapılar ancak sahil bölgesinde yoğun olarak karşımıza çıkmaktadır. Konutların zemin katları tabandaki 1slaklık ve nemden dolayı yaşama alanı olarak kullanılmamış, genel hizmetlere ve hayvanların barınması için ayrılmıştır. Üst kat ise esas yaşama katı olarak düzenlenmiştir. Geleneksel konutların en önemli özelliği üç kuşağın bir arada yaşadığı geleneksel aile tipine uygun bir planlama ve dizaynın söz konusu olmasıdır. İlin değişik bölgelerinde karşılaştığımız konut tipleri arasında tespit edebileceğimiz farklılıklar büyük ölçüde yüzeysel olup aslında işlev, plan şeması ve mekânsal organizasyon hemen hemen birbirinin tekrarıdır

\subsubsection{Evi Oluşturan Birimler:}

Evlerin cümle kapılarının önünde yer alan ve düzeltilip zemini taşla döşenerek taşlık adı verilen bölgeden çift kanatlı kapılarla girilen kulluğun esas işlevi dış dünya ile ev arasındaki iletişimi sağlamaktır. Ayrıca ziraatla ilgili aletler, odun vs. burada muhafaza edilmiş, hergil ve el değirmenleri buraya yerleştirilmiştir. Çift yönden girişi olan ve zemini sıkıştırılmış toprak olan kulluktan üst kata çıkışı sağlayan merdivenlerin altında kalan boşluk depo olarak değerlendirilmiştir. Merdivenlerin önünde pabuçluk yer almaktadır. Bu kısmın zemini ahşapla kaplanmıştır ve toprak zeminle arasında $10 \mathrm{~cm}$. kadar bir kot farkı bulunmaktadır.

Kırsal kesimde yaşayan insanların temel geçim kaynaklarından birisinin hayvancılık olması nedeniyle her evin zemin katında tam adı verilen ahır bölmesi yer almaktadır. Genellikle her evin iki ahır bölmesi vardır. Bunlardan birisi ineklerin, diğeri ise öküzlerin barınması içindir ancak eğer ev hisseli ise bu ayrım ortadan kalkmaktadır. Ahıra girişi sağlayan kapının tam karşısında temek boşluğu yer alır, yaklaşık olarak 20x20 cm. ebadındadır. Temek, gübrenin dışarı atılmasını sağladığı gibi temiz hava ve 1şık ihtiyacını da karşılar. Ahırda hayvanların bağlandığı kenarda afur adı verilen ahşap yemlik yer almaktadır.

Üst katta, odalar arasında yer alan geniş hacim evin sofasıdır. Bu mekan sahilde aralık, iç bölgelerde ise çardak olarak adlandırılır. Sofaya geleneksel Türk konutlarında olduğu gibi özel bir işlev yüklenmemiştir. Odalar arasında sirkülasyonu sağladığı gibi aynı zamanda ailenin günlük hayatı paylaştıkları toplanma, ortak yaşama ve kullanım mekanıdır. Burada pencere kenarlarına yerleştirilen ahşap sedirlerde oturulabilir, yer sofrasında yemek yenilebilir. Ayrıca ev içi üretim de kısmen burada gerçekleştirilir. Örneğin geçmişte kullanılan dokuma tezgahlarının, düzen veya kıygak, kurulu olduğu yer burasıdır. Sofa gerekirse kışa hazırlık faaliyetleri için de kullanılabilir. Eski köy evlerinde sofa olarak

\footnotetext{
${ }^{4}$ İç kesimde ve dağ köylerinde konak tarzında üç katlı konutlar mevcuttur. Örneğin Ulus ilçesi Eldeş Köyü Emirdaş Mahallesinde bulunan Niyazi Altaş Konağı 1930'lu yıllarda Bartın' dan gelen bir usta grubu tarafından köy ağası Molla Yakup için inşa ettirilmiştir.
} 
nitelenebilecek olan bu orta mekanın tavan kaplaması çakılmamıştır. Bu sayede kirişlerden faydalanarak sabitlenen ve kol adı verilen çubuklara mısır dizileri asılmış ve kurutulması sağlanmıştır. Sofa payı olarak belirlenen genişlik 3,5 metre kadardır. Köy evlerinde yaşam katında yer alan odaların arasında ara yer ya da yalnızca ara adı verilen ve ses izolasyonunu da sağlayan bir koridorla çardaktan sergü adı verilen alana ulaşılır. Bazı evlerde bu geçiş mekanı bulunmaz, sergüye doğrudan odalardaki pencereler veya bir kapı vasıtasıyla ulaşılır. Sergü evin güneş alan cephesinde yer alır ve ana kütleden $1 \mathrm{~m}$. kadar dışarı taşırılmıştır. Üç tarafı açıktır ve önünde çatıyı destekleyen ahşap direkler bulunmaktadır. Burada kışa hazırlık amaciyla misır, bulgur, pestil, biber, patlıcan, fasulye, kabak, gibi yiyecekler kurutulur; ayrica çamaşır asılır, bulaşık yıkanır, artan yemekler bozulmaması için burada muhafaza edilir. Kurutma işlemi düzgün tahtalar üzerinde ya da kendirden imal edilen dokumalar üzerinde gerçekleştirilir.

Sofanın bir kenarına yerleştirilen apteslik ve helanın bulunduğu alan apteslik yannı olarak adlandırılmaktadır. Hela köylerde evin cephesinden bir miktar dışarı kaydırılmıştır. Altındaki açık alan bokluk olarak adlandırılır. Sofanın köşesindeki hela ve abdestlikte zuhur eden atıklar çörtle adı verilen ağaç oluklarla birbirlerinden bağımsız olarak dışarı akıtılarak evden uzaklaştırılmıştır. Bu atıkların birbirine karıştırılmadan ayrı ayrı sistemlerle evden uzaklaştırılması halk tarafından İslami inançlarla açıklanmaktadır. Helanın ve abdestliğin dış duvar kaplaması havalandırmayı sağlayarak çürümeyi önlemek amacıyla seyrek bir şekilde yapılmıştır. Abdestlik, abdest almanın yanı sıra bulaşık yıkama, kişisel temizlik vb. faaliyetler için de kullanılan bir bölgedir. Burada ahşap bir tezgah ve lavabo olarak tanımlanabilecek içi meyilli bir obje yer almaktadır. Su güğümleri ve bir miktar mutfak malzemesi buradaki raflarda muhafaza edilmiştir. Geçmişte evlerde su tesisatı bulunmadığından su eve ahşap, pişmiş toprak kaplarla ve güğümlerle çeşme, kuyu ve derelerden taşınmış ve kullanılmıştır. Apteslik yannı olarak nitelenen alandan dar bir koridorla ulaşılan helada ahşap döşemede üçgen şeklinde açılan hela deliği bulunmaktadır. Burada temizlik ibriklerle taşınan su ile gerçekleştirilmiştir.

Oda geleneksel konutlarda planlama açısından en önemli mimari öğedir ve ev içi hayatın idame ettirildiği esas mekan burasıdır. Sayısı ve büyüklüğü hane sahibinin maddi durumuna ve ailenin genişliğine göre iki ile dört arasında değişmektedir. Odalar geleneksel geniş aileyi oluşturan daha küçük ailelerin mahrem alanıdır. Kare ya da kareye yakın dikdörtgen planlı olan odalarda yer alan hamam dolabı, ocak nişi, kiler dolabı, sedir, sergen vb. elemanlar odada yemek pişirme, yemek yeme, yıkanma, dinlenme,uyuma, oturma gibi birbirinden oldukça farklı faaliyetlerin icra edilmesine olanak verir ve bu sayede evde halkı birbirini rahatsız etmeden ve özel hayatlarına müdahale etmeden yaşamlarını devam ettirebilir. Bundan dolayıdır ki her oda, içerisindeki döşeme ile ailenin hayatını idame ettirebilmesine yeterli birbirinden bağımsız ayrı bir birim, yani ev olduğu için kırsal bölgede ev ve oda kelimeleri aynı manada kullanılmıştır.

Oda içerisinde bir duvar, ocak nişi ve dolaplar için ayrılmıştır. Duvarın ortasına kurulan ve genellikle baca olarak adlandırılan ocağın evin dış yüzüne bakan tarafına hamam dolabı diğer tarafına ise diğer dolaplar yerleştirilmiştir. Bu şema hamam dolabında oluşan kirli suyun 
kolayca dışarı atılabilmesini sağlayan pratik bir çözümdür. Taştan inşa edilen ağır ocaklar odanın altındaki ocak kirişleri ile taşınır. Ocağın altındaki toprak katman ve taş döşeme ise yangına karşı düşünülmüş bir çözümdür. Ocaklar 1sınma, su 1sıtma ve yemek pişirme gibi amaçlar için kullanılmıştır. Yakıt olarak çevrede bolca bulunan ormanlardan kolayca temin edilen ağaç kütükleri kullanılmıştır. Ocakta pişirme ve 1sıtma işlemi sacayaklar üzerinde gerçekleştirilir. Kırsal kesime ısınma amaçlı olarak sobanın girişi, bazı istisnalar bir kenarda bırakılacak olursa, çok geç tarihlerde meydana gelmiştir. Bugün bile 1sınma ihtiyacını bu şekilde gideren evlere tesadüf etmek mümkündür. Ocak nişinin hemen üzerindeki taş raf kırsal bölgede sergen olarak adlandırılmaktadır. Burası mum, gaz lambası, idare, çıra, kibrit, kav gibi aydınlatma ile ilgili araç ve gereçlerin muhafaza edildiği bölümdür. Köylerde aydınlanma ihtiyacı uzun süre reçineli ağaçlardan elde edilen ve çıra adı verilen elemanlarla karşılanmıştır. Daha sonra ise, özellikle kırklı yıllardan itibaren, gazla çalışan lambalar günlük hayata girmiştir. Hamam dolabı yıkanmanın dışında yük dolabı olarak da kullanılmıştır. Dolabın zeminden yüksekliği yaklaşık $30 \mathrm{~cm}$. kadardır. Bu bölmenin içerisinde bir kapak bulunmaktadır.Yükler boşaltılıp kapak açılınca yıkanma faaliyetine hazır olmaktadır. Temizlik işlemi rahne adı verilen alçak taburelere oturularak, ocakta güğümlerde 1sıtılan su ile yerine getirilmiştir. Bu kısmın zemini hafifçe dışarıya doğru meyillidir ve kirli su çörtle adı verilen ahşap oluklarla dışarı akıtılmıştır. Yıkanma faaliyeti bitince kapak kapatılır ve yükler eski yerine yerleştirilir. Bu akılcı çözüm oda içerisinde mekandan azami şekilde tasarruf edilmesini sağlamıştır. Ocak nişinin diğer tarafında bulunan, dolaplarsa pişirme ile ilgili mutfak aletlerinin, sofra malzemelerinin, bir miktar yiyeceğin, ekmeğin ve kahve takımlarının muhafaza edildiği bölümdür. Kiler dolabında birkaç gün yetecek kadar yiyecek bulundurulur. Köy evlerinde rastladığımız, kilerin hemen altında bulunan ve pek çok evde yakacak odun depolanan dolaba- kuzuluk -bazı evlerde değişik bir işlev yüklenmiştir. Bu alan soğuk kış günlerini ahırda geçiremeyecek kadar zayıf ve küçük buzağı ve kuzulara ayrılmıştır. Oda içerisinde pencereli duvarlara paralel olarak iki ya da üç yönden yerleştirilen yaklaşık olarak kırk santim yüksekliğe ve bir metre kadar da genişliğe sahip olan sedirler - set veya kerevet - oturmak, dinlenmek ve eğer çok yüksek ve dar değilse yatmak içindir. Ahşaptan imal edilen sedirin üzerine yaygu adı verilen dokumalar ve yastıklar konularak oturulur, yün yataklar serilerek yatılırdı. Gene oturma amacıyla sökü adı verilen arkalıksız iskemleler de kullanılmıştır. Odanın ortasındaki boş alan ise ahşap sofra altları üzerine bakır sinilerin yerleştirilip yemeğin yendiği ve eğer gerekirse yatakların serilip uyunduğu bölgedir.

\subsubsection{Geleneksel Konutlarda Tavan}

Bartın ilinin kırsal kesiminde karşılaştığımız geleneksel ahşap konutlar mekana ferahlık duygusu katan yüksek tavanlarıyla dikkat çekmektedirler. Esas yaşama alanının yer aldığı birinci kattaki mekanlar için geçerli olan bu uygulama, genel hizmetler, hayvancilık ve depolama amacıyla kullanılan zemin katta değişir ve mekanlar biraz daha basıklaşır. Ayrıca bu katın tavan döşemesi çakılmamıştır. Tavan kaplaması yerli ustalar tarafından zar olarak adlandırılmaktadır. Konutlarda kirişlemesi alttan kaplamalı düz ahşap tavanın yanı sıra çıtalarla meydana getirilen tekne tavanların da uygulandığı görülür. Odalarda, özellikle misafirlerin ağırlandığı odaların tavanlarında, tavanın göbek adı verilen orta bölümünde 
süsleme amaciyla geometrik motiflerden oluşan ve çıtalarla oluşturulan ahşap bezemeler bulunmaktadir.

\subsubsection{Geleneksel Konutlarda Döşeme}

Kırsal kesimde yer alan geleneksel konutların zemin katlarında yer alan kulluk bölümünün tabanı istisnasız her evde sıkıştırılmış topraktır. Ahır bölmesinde taban, kestane gibi hayvanların sidiğinde ve dışkısında bulunan asitlere dayanıklı olduğu düşünülen ağaçlardan elde edilen hatıllarla kaplanmıştır. Üst katın zemini ise tümüyle ahşap kaplamadır ve döşemeyi oluşturan kaplama tahtaları demir çivilerle kirişlere çakılmıştır.

\subsubsection{Geleneksel Konutlarda Merdiven}

Kırsal kesimde basak ya da iskele olarak adlandırılan ve zemin kat ile üst kat arasında iletişimi sağlayan merdivenler genellikle tek kolludur, ancak çift kollu merdivenlere de rastlamak mümkündür.. Merdiven kenarındaki korkuluklar tırabzon olarak adlandırılmaktadır

\subsubsection{Geleneksel Konutlarda Kapı}

Bölgede evlere giriş çıkış çift kanatlı ahşap cümle kapıları ile sağlanmıştır. Genellikle her evin iki cümle kapısı bulunmaktadır. Bu kapılar ahırda barınan hayvanların giriş çıkışını kolaylaştırmak amacıyla oldukça büyük tutulmuşlardır Kapı kanatları arka taraftan demir kuşaklarla birbirlerine kenetlenen kerestelerden oluşturulmuştur. Cümle kapılarının genişliği 2 metre kadardır. Yükseklik ise iki metreyi biraz aşar. Bu kapıların üzerinde hava ve 1 şı sağlayan parmaklıklar yer alır Kapılara yerleştirilen ve birbirinden pek de farklı olmayan demir kapı tokmakları yerel demirci ustaları tarafından imal edilmiştir. İç mekanda yer alan kapılar tek kanatlı, basit ve gösterişsizdir. Kısa kenarı 70-90 cm., yüksekliği ise 190-200 cm.dir. Kapılar ahşap kasalara demir menteşelerle sabitlenmiştir.

\subsubsection{Geleneksel Konutlarda Pencere}

Köy evlerinde zemin katlarda pencere kullanımı pek görülmez. Bu kat 1şık ve hava ihtiyacını ışıklık veya parmaklık olarak adlandırılan küçük açıklıklar vasıtasıyla giderir. Ayrıca temek adı verilen ahır pencereleri de bulunmaktadır. Üst katta ise odalara (her birinde dört adet) ve sofaya açılan dikdörtgen biçimli pencereler yer alır. Günlük hayatın önemli bir kısmının geçtiği odalar yapı ustaları tarafından binanın strüktürüne zarar vermeden mümkün olduğu kadar fazla pencere ile dış dünyaya açılmasının nedeni estetik kaygılardan çok ısınma, aydınlanma, ve havalandırma gibi işlevsel arzulardan kaynaklanmaktadır. Zira bölge güneşin sıcak yüzünü pek göstermediği, nemli ve yağışlı bir iklime sahiptir. Böylece gündüz saatlerinde bol ışık alan, sağlıklı, aydınlık ve ferah iç mekanlar elde edilebilmiştir. Bu pencereler üstten ya da yandan sürmelidir. Yandan sürmeli pencereler aç1lıp kapatılabilen ahşap pencere kapakları ile donatılmıştır. Pencerelerin alt pervazlarında oyma süslemeler bulunmaktadır. Pencerelerin genişliği $70-50 \mathrm{~cm}$., yüksekliği ise $80-100 \mathrm{~cm}$. arasında değişir. Pencere boşluğu duvar yüksekliği 1-1,5 metreye ulaşınca bırakılmaktadır. 


\subsubsection{Kilit Sistemi}

Köy evlerinde kulluk bölmesine açılan büyük cümle kapılarında genellikle ahşaptan imal edilen bazen de demir malzemeden üretilen kilitler kullanılmışken, iç kapılarda ve dolaplarda kancalı kilitler karşımıza çıkmaktadır. Bunlara çövürge adı verilmektedir. $\mathrm{Bu}$ kilitlerden ahşap olan örnekler bizzat yapı ustaları tarafından, demir kilitler ise bazı köylerde karşılaştığımız ${ }^{5}$ demircilerce üretilmiştir. Dış kapıların sağlamlığını arttırmak için kap1 arkasına demirden dayak verme uygulaması söz konusudur. Ancak özellikle uzak dağ köylerinde dayak demir değil ahşap malzemeden imal edilmiştir.

\subsubsection{Geleneksel Konutlarda Cephe Düzeni}

Çok sade ve basit bir cephe düzenine sahip olan geleneksel konutlarda bu düzeni oluşturan ana unsurlar kapı, pencere, 1şıklık, yangın penceresi ve katlar arasında yer alan silmelerdir. Cephe düzeninde süslemeye pek rastlanmaz, bunun tek istisnası pencere pervazlarındaki süslemelerdir. Zemin kat, üst kattan farklı olarak, olabildiğince dış dünyaya kapalı tutulmuştur. Bu katın cephelerinde yalnızca giriş çıkışı sağlayan kapı, 1şık ve hava

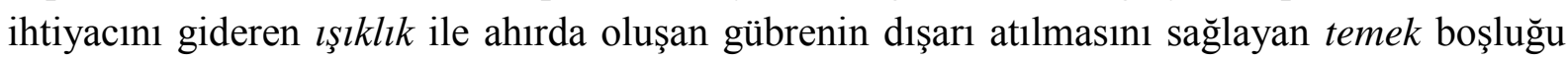
bulunmaktadır. Zemin kattaki bu sağır duvarların nedeni mahremiyetten çok, sert geçen kışlar ile statik kaygılardır. Zira zemin katın ahşap duvarları üst kat ile çatıyı taşıyan yegane unsurdur.

Evlerde ana cephe olan giriş cephesini kıbleye çevirme arzusu mevcuttur. Ancak topografik yap1 bu yönlendirmeye izin vermemişse evin cepheleri araziye göre uydurulmuştur. Bazı evlerde ise cephe yola çevrilmiştir. Bu arzunun kaynağı olarak İslam inancının yanı sıra işlevsel kaygılar da gösterilebilir. Zira nemli ve çürütücü bir iklimin hakim olduğu bu coğrafyada evi güneşle buluşturabilmek ev için olduğu kadar evde yaşayan insanlar için de faydalı sonuçlar verecektir. Ana cephenin dışında evin bazı unsurlarında da bir genelleme yapılabilecek kadar tutarlı bir biçimde yerleştirme söz konusudur. Örneğin sergi bölümü güneş, abdestlik ve tuvalet ise rüzgar alan cepheye yerleştirilmiştir. Bunun en önemli nedeni iklimdir. Gene yangın bacaları da kıbleye bakacak şekilde inşa edilmişsir.

\subsubsection{Geleneksel Konutlarda Örtü Sistemi:}

Bölgede yer alan geleneksel yapıların alaturka kiremitle kaplı çatıları dört yöne eğimlidir ve saçaklar olabildiğince geniş tutulmuştur (50-80 cm.). Oturtma çatı yaygın olarak kullanılmıştır. Çatılarda yer alan ve kuzgunluk adı verilen pencere çatıyı aktarmak ve meydana gelebilecek yangınları söndürmek içindir. Ayrıca bu açıklıktan içeri süzülen ışık ve hava çatı arasının hatta sofanın aydınlanmasına ve havalanmasına yardımcı olur. Alan araştırması sırasında tesadüf edilememişse de yapı ustaları ve halk tarafından en eski çatı örtüsünün bedavra olduğu ifade edilmektedir.

\subsection{Müştemilat Yapıları}

\subsubsection{Ambar/Hambar}

\footnotetext{
${ }^{5}$ Kumluca Beldesi Zafer köyü Abdaloğlu Mahallesinde 70'li yıllarda vefat eden demirci Mehmet YAMAN geçmişte Helkeme olarak bilinen o çevreye hizmet eden bir atölye işletmiştir. Atölyesi tek katlı ahşap bir yapıdır.
} 
Geleneksel üretim ve tüketim zincirinin kopmasından önce bölgede buğdayla birlikte temel besin maddesi olarak karşımıza çıkan ve yoğun olarak tarımı yapılan mısırın depolanması ve bozulmadan muhafaza edilmesi gereksinimi ambar yapıları ile karşılanmıştır. $\mathrm{Bu}$ yapılarda ayrıca arpa, un, kurutulmuş meyve (tavşut) vb. yiyecekler de depolanmıştır. Ambarların da tıpkı samanlık yapıları gibi evin yakınlarında inşa edildiği, böylece kar yağışlarından ev halkının etkilenmesinin önlenmeye çalışıldığ özellikle geniş toprakları olan kalabalık ailelerin ambar yapılarının mevcut olduğu (bazen birden fazla), göreceli olarak daha dar tarım alanına sahip ailelerin ise bu gereksinimlerini evlerin kulluk veya sofa kısımlarında muhafaza edilen ve hergil adı verilen dikdörtgen prizma şeklinde, kapaklı büyük sandıklarla gidermeye çalıştıkları gözlemlenmiştir. Hergil gürgen, köknar veya çam ağacindan imal edilmiştir. Fare ya da böceklerin depo edilen yiyecek maddelerine zarar vermesini önlemek amacıyla hergilin yapımında lamba ve kiniş uygulamasına gidilmiştir.

Yörede ev inşası ile ambar inşası arasında teknik açıdan büyük bir fark bulunmamaktadır. Ancak ambar yapılarında - depolanan yiyecekleri korumayı amaçlayan yapılar olmaları nedeniyle- daha ince, özenli ve temiz bir işçilik söz konusudur ve inşaatında kullanılacak kerestenin mümkün olduğunca kaliteli, ince ve hatasız olmasına özen gösterilmiştir. Gene bu maksatla kapılar içeriye doğru zaviyeli olarak yapılmıştır. Samanlıkların aksine bu kapılarda madeni kilitler kullanılmıştır.

Ambar yapılarında temel olarak yalnızca büyük boyutlu düzgün taşların kullanıldığı görülür. Yapıdan bağımsız bu altyapı üzerinde ya daha küçük taşlarla yüksekliği yarım metreyi aşmayan bir kaide oluşturulmuş ya da ahşap direkler ve kirişler vasıtasıyla bir çatkı kurulmuş, daha sonra, bu tamamen taşıyıcı ve yapıya fevkani bir çehre kazandıran bu kaide üzerine esas ambar yapısı inşa edilmiştir. Böylece depo alanının zemindeki nem ve sslaklıktan uzak tutulması sağlanmıştır. Ambar yapıları yı̆̆ma tekniğiyle inşa edilmiştir ve yapı ustalarının tanımlamasıyla dört çatmadan ibarettir.

Ambarlar genellikle kare ya da kareye yakın dikdörtgen planlı ve 3x3 metre boyutlarındadır. Önünde meyvelerin muhafaza edildiği çardak veya sergü adı verilen bölüm yer alır. Ambarın girişine çardaktan ulaşılır. Çardağa ise iskele veya basak olarak adlandırılan ahşap merdivenlerle çıkılır. İç mekan iki ana bölüme ayrılmıştır: Ortada kandil adı verilen dört tane derin bölme bulunmaktadır. Esas depo kısmı burasıdır, öğütülmemiş hububat burada muhafaza edilmektedir. Kenarlarında iniş ve çıkışı sağlamak amacıyla basak adı verilen ahşap çıkıntılar bırakılmıştır. Girişin karşısındaki ve iki yandaki alansa ahşap darabalarla bölüntüye uğratılarak bölmelere ayrılmıştır. Her biri göz adını alan bu elemanlar un, kurutulmuş meyve gibi yiyeceklerin depolanması için ayrılmıştır. Genellikle dokuz tane göz bulunur. Ambarlar bedavra veya oluklu kiremitle kapatılan kırma çatı ile örtülüdür.

\subsubsection{Tavşut Firını}

$\mathrm{Bu}$ firınlar bölgede tavşut olarak bilinen elma ya da armut kurusunun elde edildiği küçük boyutlu yapılardır. Genellikle eve yakın, düz bir alanda inşa edilirler. Tavşut 
fırınlarının fırınlardan en büyük farkı çok daha küçük boyutlu olmasıdır. Bazı aileler ayrı bir tavşut fırınına ihtiyaç duymamış, bu iş için de ekmek fırınlarını kullanmışlardır.

Tavşut fırınlarının inşası şu şekildedir: Önce arazi düzeltilir, daha sonra 30 santim kadar kazılarak düzgün boyutlu taşlarla temeller oluşturulur. Zemine taş döşenir. Ortaya düzgün bir sırık dikilir, sırığa ucunda kömür parçası olan bir, bir buçuk metre kadar uzunluğu olan bir sicim bağlanır, ipin ucundan tutularak dönülür ve böylece fırının dış duvarlarının yeri çizilir. Bu şekilde dairesel bir form elde edilir. Daha sonra fırının inşasına başlanır. İnşa malzemesi tarlalardan ya da dere yataklarından toplanan düzgün boyutlu küçük taşlar (persek taş) kullanılır. Bu taşlar örülürken birbirlerine uyacak şekilde yerleştirilir. Ayrıca içerisine saman tozu veya kıtık katılan çamur harcı da bağlayıcı olarak kullanılır. Örme işlemi sırasında usta firının içindedir, ona gerekli malzemeyi dışarıda bulunan bir amele vermektedir. Fırın ustanın hareket edemeyeceği kadar daraldığı zaman usta firının içerisinden çıkar ve dışardan örmeye devam eder. Örme işlemi tam üste konulan ve göbek adı verilen kare şeklinde büyük bir kapak taşının yerleştirilmesiyle sona erer. Ağaç bir tokmakla iyice yerine sabitlenen göbeğin üstü çamurla iyice sıvanır. Böylece ortaya kubbeyi andıran bir yapı ortaya çıkar. $\mathrm{Bu}$ yapı tamamlanınca firın üç taraftan bir sıra taşla daha dönülür, arada kalan boşluk çamurla doldurulur. Ortadaki esas firın yapısı yaklaşık olarak 3 metre çapındadır. Dış kabuğun örülmesiyle firın üç tarafı birbirine dik gelen bir kenarı ise dışbükey bir forma kavuşur $(3 \mathrm{x} 4$ metre ebatlarında). Giriş açıklığı 50x60 cm. boyutlarındadır. Tavşut fırınlarının kullanımı misır firınları ile aynıdır.

\subsubsection{Samanlık/Samanhane}

Hayvancılığın günlük hayatta önemli bir yer tuttuğu bölgede her evin ahşap bir samanlığı bulunmaktadır. Kışın yağan kar göz önünde bulundurularak eve yakın, ulaşılması kolay bir yerde inşa edilen bu yapılar tek mekanlı, basit örneklerdir. Bazı köylerde, harman yerinin yakınlarına yerleştirilmiş samanlık yapıları mevcuttur. Dikdörtgen planlı samanlık yapılarının ön cephesinde yer alan çift kanatlı kapılar depolanacak samanın giriş ve çıkışını kolaylaştırmak maksadıyla oldukça geniş tutulmuştur. Bu kapılar üzerinde ahşaptan imal edilmiş irilikleri ve kaba görünümleriyle dikkat çeken kilit sistemleri mevcuttur.

Samanlıklar inşa edilmeden önce arazi elden geldiğince düzeltilmiş ve temel olarak bir iki sıra taş kullanılarak yapı yerden yükseltilmiştir. Böylece hem yap1 hem de yapıda muhafaza edilen hayvan yemi, alaf, toprakta bulunan nemin çürütücü etkisinden uzak tutulmaya çalışılmıştır.

Yapı ustalarının samanlık yapılarının inşasında kullandıkları esas teknik yığma tekniğidir. En eski yapılarda inşa eylemi soyulan, budaklarından ayrılan, hafifçe düzeltilen ve uçları kertilen tomrukların üst üste yığılması yoluyla gerçekleştirilmiştir. Bunlara göre daha geç tarihlerde inşa edilen samanlıklarsa hatıl haline getirilmiş kerestelerle inşa edilmiştir. İç kesimlerde; inşaatta kullanılabilecek kalitede ahşap malzemenin azalması ve kesimin yasaklanmasıyla birlikte çevreden elde edilen özlü toprağın su ve samanla birlikte yoğrulması ve kalıplanmasıyla elde edilen kerpiç malzeme ile inşa edilmiş olan samanlık yapıları da görülebilir. Bu tür yapılarda duvarları sağlamlaştırmak ve deforme olmasını önlemek 
amacıyla cilit adı verilen yatay ahşap hatıllar kullanılmıştır. Çift yöne eğimli kırma çatı ile örtülü olan samanlık yapılarında çatının örtüsünde kullanılan örtü elemanları önce bedavra, sonra yerli kiremit ve en son olarak da sacdır.

\subsubsection{Karaltı}

Karaltı adı verilen yapılar, kızak ve öküz arabalarının kar ve yağmura karşı muhafazasını sağlamak amacıyla evin hemen yakınlarına inşa edilen, dört tane ahşap direğe oturan bir çatıdan meydana gelen, basit ama işlevsel yapılardır.

\subsubsection{Kuyu}

Su kuyuları yeraltında bulunan su tabakasına ulaşıncaya kadar toprağın kazılması ile meydana getirilen yuvarlak ve derin çukurlardır. Derinliği yerine ve arazinin yapısına göre değişir. Bu yapılar kaynak sularının yetersiz olduğu durum ve alanlarda karşımıza çıkar. Kuyunun kazılmasından sonra ustalar kuyunun etrafını gerçekleşebilecek olan çökmeleri önlemek amaciyla taşla ancak harç kullanmadan kuru duvar şeklinde örer. Kimi yerlerde kuyunun ağzına bilezik adı verilen ortası delik büyük bir taş yerleştirilir. Bahçe içerisinde yer alan kuyular ayrıca sıcak aylarda yiyeceklerin bozulmasını önlemek ve soğutmak için, bir nevi buzdolabı gibi de kullanılmıştır.

\subsection{Ortak Kullanım Alanları}

\subsubsection{Firın}

Kırsal bölgede misır, ambarlarda muhafaza edilmek üzere depolanmadan önce firınlarda kurutulmaktadır. Bu işlemin amacı mısırın çürümesini ve bozulmasını mümkün olduğunca önleyebilmektir. Eğer tavşut firını mevcut değilse bu yapılarda elma ve armut da kurutulabilmektedir. Ancak yakacak tasarrufu için bu seçenek pek tercih edilmemiştir. Fırın bir köyün ya da mahallenin ortak malı olabileceği gibi yalnızca bir haneye ait de olabilir. Eğer köyün ortak malıysa fırının boyutları büyür ve daha özenli bir işçilik yansıtır.

$\mathrm{Bu}$ yapılar çaylardan toplanan düzgün kenarlı kayran taşları ile inşa edilmiştir. Bağlayıcı olarak, içerisine bir miktar saman katılan killi çamur harcı veya kum-kireç harcı kullanılmıştır. Fırınlar inşa edilirken yarım metrelik bir temel üzerine bir metre kadar yüksekliği olan bir altyapı oluşturulmuş ve bunun üzerine de esas fırın inşa edilmiştir. Önünde bir insanın girip çıkabileceği genişlikte bir fırın deliği ve bunun arkasında da yanma ve kurutma işleminin gerçekleştiği firın boşluğu yer almaktadır. Isı kaybını önlemek ve izolasyon sağlamak amacıyla duvarlar mümkün mertebe kalın tutulmuştur. Yapının üst örtüsü basık kubbeyi andırmaktadır.

Fırınların kullanımı şöyledir: İç mekân temizlenir, yakıt olarak odun yığılır, tutuşturulur ve köz haline gelmesi beklenir. Daha sonra bu köz üç kenara ağaç sırıklarla itilir, ve ortadaki boşluğa kurutulmak istenen mısırlar istiflenir. Fırın deliği büyük bir kapak taşı ile kapatılır ve sıcaklığın dışarı kaçmaması için çamurla sıvanır. Fırın yavaş yavaş soğurken bu arada mısırlar da kurur, depolanmaya ve öğütülmeye hazır hale gelir. 


\subsubsection{Köyodası}

Özbaşı Köyü Yukarımahalle Taşınyanı mevkiindeki köy odası araştırma bölgesinde tespit edilebilen ve orijinalliğini korumayı başaran nadir örneklerden biridir. Diğer bölgelerdeki köy odalarının bozularak ${ }^{6}$ yerine cami veya yeni oda inşa edildiği öğrenilmiştir.

Geçmişte bu coğrafyadaki her köyün ayrı bir camisi olmadığı, fiziki olarak birbirlerine yakın birkaç köy için ortak bir cuma camisi inşa edildiği ve halkın günlük ibadetini köy odalarında yerine getirdiği anlaşılmaktadır. Cuma ve bayram namazları içinse Cuma camileri kullanılmıştır. Bu uygulama Kuzeybatı Anadolu' da kökeni fetih, iskan, Türkleşme ve İslamlaşma yıllarına kadar dayanan eski bir gelenektir ${ }^{7}$ ve başka bölgelerde de karşımıza çıkmaktadır. Örneğin Kastamonu ili Pınarbaşı(eski Zarı) ilçesinde Hicri 1253/Miladi 1837 yılında ahşap yığma tekniğiyle inşa edilen Eski Cami, üç ayrı köyün (Sümenler, Yamanlar, Uzla Köyleri) cuma ve bayram namazlarını ifa ettikleri ortak bir yapıdır ve bunun dışında kalan vakit namazları odalarda kılınmıştır.

İbadetin dışında köy odalarının misafir ağırlanması, toplantı yapılması, toplu iftar yemekleri düzenlenmesi, köy çocuklarına dini bilgilerin öğretilmesi, köyün erkeklerinin toplanıp çeşitli oyunlar oynaması (Yüzük saklama) gibi işlevlere de sahip olduğu tespit edilmiştir. Özbaşı köyündeki Köyodası 1957 yılında daha eski bir köyodası yıkılarak yerine inşa edilmiştir. Üç katlı ahşap yığma bir yapıdır, gerek dış görünümü ve gerekse inşa tekniğiyle geleneksel ahşap konutlardan büyük bir farkı bulunmamaktadır. Binanın alt katında at ahırı olarak kullanılan tam vardır. Birinci katta ocaklı bir misafir odası, apteslik, ayakkabılık ve hela, ikinci katta ise mescit yer alır. Mescidin güneyinde kıble yönünde ahşap bir mihrap nişi bulunmaktadır. Mescidin kuzeyinde daraba adı verilen ahşap bir bölme duvarı kadınlarla erkeklerin ibadet alanını birbirinden ayırmıştır. Kadınlar için ayrılan bölüme binanın dışından ayrı bir merdivenle ulaşılabilmektedir. İkinci bir merdivenin yapılışındaki amaç mahremiyeti tesis etmektir. Yapı geniş bir temel çukuru kazılmadan ve temel duvarı örülmeden köşelere yerleştirilen büyük kaya parçalarının üzerine inşa edilmiştir. Karaduvar tekniği ile inşa edilen yapıda malzeme olarak kayın ve köknar ağacı kullanılmıştır. Köşelerdeki geçmelere köylüler çinti geçme adını vermektedir. Dökme adı verilen kirişler dayanıklı kestane ve meşe ağaçlarından elde edilmiştir. Kırma çatısı oluklu kiremitle kaplıdır ve çatıda yangın penceresi bulunmaktadır.

\subsubsection{Cami/Mescit}

Dini mimarlık yapıtları olan cami ve mescitler tek mekânlı, kareye yakın dikdörtgen ya da dikdörtgen planlı, kadınlar mahfili bulunan, kimi zaman bir son cemaat yerine sahip, kırma çatı ile örtülü basit ve tümüyle işlevsel yapılardır. Genellikle ağaç malzemeden inşa edilmiş olan bu yapıların neredeyse tamamı günümüzde modern malzemelerle yenilenmiştir.

\footnotetext{
${ }^{6}$ Karadeniz'in bazı bölgelerinde olduğu gibi Bartın' da da “yıkmak" yerine "bozmak" ya da "sökmek" tabirleri kullanılmaktadır.

${ }^{7}$ Ayverdi, 1966: 120-133.
} 


\subsubsection{Su Değirmeni}

Köylerde karşımıza çıkan ve su gücüyle çalışan değirmenler genellikle az eğimli bir arazi üzerinde akarsulara yakın bölgelerde inşa edilmiştir. Sağlam taş temeller üzerine ahşap malzemeden yığma tekniği ile inşa edilen bu yapılar kırma çatı ile örülüdür. Değirmenin çalışmasını sağlayan su, büyük ahşap oluklarla getirilmiştir. Oluklar kalın ve düz köknar ağaçlarının içinin baltayla oyulmasıyla oluşturulmuştur. Bu olukların değirmenle bitiştirildiği bölgede, istenince suyu kesen ya da serbest bırakan bir düzenek mevcuttur. Bu ahşap düzenek baltacuk ayarı olarak adlandırılmaktadır. Değirmene alınan su çarkları döndürmesini müteakiben zemindeki bir kanaldan dışarı atılmıştır.

Genellikle dikdörtgen planlı olan su değirmenleri iki bölümden oluşmaktadır. Bunlardan ilki değirmencinin odasıdır. Burada taş bir ocak, dolap ve sedir bulunmaktadır. İkinci kısım esas değirmenin bulunduğu mekândır. Bu kısımda değirmen taşları, çarklar, oluklar ve sandıklar yer alır. Öğütme işlemi üst üste konulmuş iki silindirik taş arasında gerçekleşir. Alttaki taş sabit, üstteki ise hareketlidir. Değirmen taşları Eflani’ den getirilmiştir. Taşların üzerinde tekne adı verilen ters piramit şeklinde ahşap bir eleman yer almaktadır. Öğ̈̈tülmek istenen arpa, buğday ya da mısır bu tekne içerisine alınır ve düzenli bir şekilde taşların üzerine bırakılır. Üstte bulunan taşın ortasında yer alan delikten geçen hububat iki taş arasında sıkışarak ezilir, un ve kepek haline gelir. Bunlar taşların kenarından dışarıya atılır. Elenmesinden sonra un ve kepek ayrı ayrı çuvallara doldurulur, sahibine teslim edilir. Öğ̈̈ülen unun bir kısmı da değirmenciye bırakılır.

\subsection{6. Çeşme/Buğar}

Halk tarafından buğar (pınar) olarak da adlandırdığı çeşmeler insanların temiz su ihtiyacını karşılayan ortak kullanım alanlarıdır. Yakın zamanlara kadar kullanılan köy çeşmelerinin mimari olarak herhangi bir özelliği ve değeri bulunmamaktadır. Bu çeşmeler suya dayanıklı ağaçlardan elde edilen kütüklerin içinin oyulmasıyla elde edilen ve çanak adı verilen bir yalak ile suyu bu yalağa akıtan bir oluktan ibarettir. Su yüksek bölgelerdeki doğal su kaynaklarından ahşap borularla taşınmıştır.

\subsubsection{Köprü}

Bölgenin topografyası iletişim ve ulaşım amacıyla birçok yerde köprü kurmayı zorunlu kılmıştır. Yakın zamanlara kadar bu amaçla ağaçtan inşa edilen köprüler kullanılmıştır. Bu köprüler yaya olarak geçmeye imkân sağlayan basit yapılardır.

\section{Yapı Malzemesi}

Geleneksel yapıların inşasında yararlanılan başlıca yapı malzemeleri ahşap, kerpiç, taş, tuğla ve kiremittir. Bunlar yakın çevreden kolaylıkla temin edilebilen içerisinde yer aldıkları coğrafya şartları ve iklime uyumlu doğal malzemelerdir. 


\subsection{Ahşap}

Sık orman örtüsüne sahip olan bölgenin ana yapım malzemesi ahşaptır ${ }^{8}$. Bölgede kullanılan başlıca ağaç türleri kestane, gürgen, köknar, ardıç, dişbudak, çınar, çam, kayın, meşe ve dağ kavağıdır. Bu ağaçların özel kesim zamanları bulunmaktadır. Buna vakit kesimi adı verilir. Vakit kesimine riayet edilmezse ağaç çürür, kurtlanır, böceklenir. Eğer bu zamana riayet edilmişse ağaç hem sağlam olur, hem de kolay soyulup işlenir. Kesim bazı bölgelerde ayın eskisine (dolunay) denk getirilir. Yeni ay zamanı kesim yapılmaz. Kesim sırasında ağacın düzgün olmasına dikkat edilir, genç ağaçlar pek kesilmez, ayrıca dağların güneş gören güney yamaçlarında yetişen ağaçların daha sağlam olduğuna inanılır ve onların tercih edilmesine özen gösterilir..

Bazı ağaçlar (Çam, çınar, dişbudak, kestane, ardıç, meşe ve köknar vs.) su çekilince,yapraklar delindiği zaman yani sonbaharda, zemheride kesilmelidir. Bazı ağaçlarsa (kavak vs.) su yürümeden, ağaç gediklenmeden (tomurcuklanmadan), delisu zamanı (martta) ilkbaharda kesilmelidir. Kayın ağacı ise yazın, ağustos ayında kesilmelidir.

Çınar (kavlak) ağacı büyük ölçüde dere ve yol kenarlarında yetişen, ustalarca esnek olarak nitelenen bir ağaçtır. Genellikle evin içerisinde bağ ağacı olarak kullanılır. Rutubetli yerlerde kurtlanır, çürür.

Kayın ağacı özellikle rutubetli yerlerde çok çabuk çürüdüğü için inşatta pek makbul tutulmazdı. Ayrıca bu ağacın yaz-kış soğuk olduğuna inanılırdı. Kullanılmak zorunda kalınırsa özellikle zemin katta tabana yakın yerlerde yada kirişlerde kullanılmaz, iç döşemede ve üst katlarda yani nem almayacağı bölgelerde kullanılırdı. İnanışa göre kayın ağacı kendisi için şöyle bir tabir kullanırmış: "Utanmasam ormandan aşağl inerken öküzün peşinde çürürüm." ". Meşe ağacı dökme ve dakma gibi yatay kirişlerin üretilmesinde kullanılmıştır. Ayrıca miyaz kütüğü ve ocak kirişi olarak da karşımıza çıkar. Kolayca çürümediği için nemli bir alan olan tuvalet ve epteslik bölümlerinde de kullanılmıştır. Köknar ağacı diğerlerine göre daha hafif bir ağaç olduğu için her zaman aranmış ve tercih edilmiştir. Hatıl olarak

\footnotetext{
${ }^{8}$ Bartın yöresinde yer alan ormanlar genellikle yayvan ve iğne yapraklı ağaçlardan oluşur. Sahil boyunca 600 metre yüksekliğe kadar olan alanın karakteristik ağaçları meşe, kayın ve gürgen; sahilden içeride ve 1.500 metreden yüksek alanlarda kayın, kestane, köknar ve çam türleri; sahil şeridinde ise ceviz, kestane ve fındık ağaçları yaygındır. Bartın ormanlarında yer alan ağaç, ağaççı, çalı, şüceyrat ve otsu bitkiler: Karaçam (Pinus nigra), Sarıçam (Pinus silvestris), Göknar (Abies bornmülleriana), Kayın ( Fagus orientalis), Meşe (Quercus L.), Gürgen (Carpinus betulus), Kestane (Castanea sativa), Kavak (Populus tremula), Ihlamur (Tilia tomentosa), Dişbudak (Fraxinus exelsior), Akçaağaç (Acer campestre), Porsuk (Taxus baccata), Üvez (Sorbus torminalis), Çınar (Platanus orientalis), Ceviz (Juglans regia), Fındık (Corylus avellana), Ormangülü (Rhododendron ponticum), Çoban Püskülü (İlex aquifolium), Mürver (Sambucus nigra), Ahududu (Rubus ideus), Bögürtlen (Rubus fruticose), Isırgan (Urtica dioica), Çilek (Fragaria vesca), Ayı Üzümü (Vaccinium), Yabani Gül (Roba canina), Fıstık Çamı (Pinus pinea), Sahil Çamı (Pinus maritima), Kızılağaç (Alnus glutinosa), Kayacık (Ostrya carpinifolia), Karaağaç (Ulmus), Ardıç (Juniperus), Yabani Kiraz (Cerasus avium), Karayemiş (Pirunus lauro cerasus), Kocayemiş (Arbutus onedo), Muşmula (Mespilus qermanica), Kızılcık (Cornus mas), Alıç (Crataegus), Defne (Laurus nobilis), Koyun Kıran (Hypericium), Çayır Otları (Graminae), Akça Kesme (Phyllaria), Kekik (Thymus), Söğüt (Salix), Kızılçam (Pinus brutia), Katırtırnağı (Spartium junceum), Üçgül (Trifolium), Servi (Cupressus sempervirens), Yalancı Akasya (Robinia pseudoacacia), Şimşir (Buxus sempervirens), Kurtbağrı (Ligustrum vulgare), Ericia arborea, Smilax, Eğrelti Otu (Aspidium) Orman Sarmaşı̆̆ı (Hedera helix), Sütleğen (Euphorbia), Karaçalı (Paliurus spina-christii), Laden (Cistus ereticus, Cistus salvifolius), Nane (Mentha). (Bartın İli Çevre Durum Raporu, 2006:76-77, 100).

${ }^{9}$ Kaynak Kişi Ahmet Necati ALTIPARMAK.
} 
kullanıldığg gibi döşemelerde ve üst katın kirişlerinde de kullanılmıştır. Çok sağlam, ancak sağlam olduğu kadar da ağır bir ağaç olan ardıç ağacından zemin katlarda döşeme, kiriş ve hatıl olarak yararlanılmıştır. Yağış ve neme maruz kalmadığı takdirde uzun yıllar sağlamlığını koruyan kavak ağacı yapıların özellikle çatı konstrüksiyonunda ve üst kirişlerde kullanılmıştır. Neme çok dayanıklı olan $\operatorname{ard} \iota c ̧$ ağacı binaların zemin katında ve hela , abdestlik gibi su gören yerlerde karşımıza çıkmaktadır. Çam ağacı döşemelerde bazen de dış duvarlarda hatıl olarak kullanılmıştır. Çok yaygın bir malzeme olarak karşımıza çıkmayan dut ağacı özellikle Kurucaşile' nin köylerinde hela ve abdestlik gibi bölgelerde kullanılmıştır. Kestane ağacından miyaz kütüğü olarak, dökmelerde; çatkı evlerde kiriş, bağ ağacı ve dikme olarak yararlanılmıştır. Ayrıca gene meşe gibi tuvalet ve abdesstlik tarafında da kullanılmıştır.

Dış duvarları oluşturan hatılları bir arada tutan ve sübek adı verilen ağaç çivilerin hatılla aynı malzemeden yapılmasına özen gösterilmiştir. Bunun nedeni farklı ağaç türlerinin farklı boyutlarda genleşmesidir.

Geçmişte kırsal bölgedeki yapıların ana örtü malzemesi olan bedavranın yapımında ise özellikle çam ve köknar ağacı tercih edilmiştir.

\subsection{Taş}

Taş malzemenin yapılarda kullanımı son derece kısıtlıdır. Özellikle temellerde ve ocak yapımında taş kullanımı karşımıza çıkmaktadır. Mısır ve tavşut fırınları ise tümüyle taştandır.

Kırsal kesimde tarlalardan çıkartılan ve kayran adı verilen düzgün taşlar kullanılmıştır. Ayrıca derelerden toplanan çay taşı da kullanılmıştır. Bu taşlar pek dayanıklı olmayan yumuşak, çürüksü kalker taşıdır. Kayalardan koparılarak elde edilen kaya taşı ise daha dayanıklıdır. Bazen taşın murç, madırga ve çekiçle yontularak düzeltildiği de olmuştur. Temel köşelerinde, çantı diplerinde ve karkas yapılarda direk altlarında karşılaştığımız büyük boyutlu battal taşlar ise üzerinde hiçbir işlem gerçekleştirilmeden kullanılmıştır. Bu büyük taşları çıkarmak için kazma ve kürekle toprak kazılır, kayalık zemine ulaşılınca iki metre boyunda sağlam bir demir çubukla (manavela demiri) kaya parçası yerinden oynatılır ve daha sonra yüzeye çıkartılırdı. Öküzlerle çekilerek inşaat alanına bin bir zahmetle getirilen bu taşlar düzgün yüzleri üstte, yumru tarafları altta kalacak şekilde temele yerleştirilirdi. Taşların arasında bağlayıcı olarak yalnızca toprak bazen de balçıklı çamur kullanılmıştır. 1950' li yıllardan itibaren ise kırsal kesimde bu amaçla kireç kullanılmaya başlanmıştır.

Ocakların yapımında iki türlü taş kullanılmıştır: Bunlar kayran taşı ve küfün taşıdır. Kayran taşının kullanıldığı örneklerde ağırlığı azaltabilmek amacıyla alt kısımlarda büyük üst kısımlarda ise göreceli olarak boyutları azalan küçük taşlar kullanılmıştır. Bikarbonatlı suların çökelmesiyle oluşan hafif, gözenekli ve baltayla bile yontulabilecek kadar yumuşak küfün (küfeki) taşının karşımıza çıktığı örneklerde ise böyle bir kaygı güdülmemiştir. Bazı örneklerde ocağın alt kısmı kayran taşından, baca kısmı ise küfün taşından örülmüştür. Bu taş genellikle ormanlarda, su kaynaklarının bulunduğu bölgelerden elde edilir ve kullanımı çok eski zamanlara kadar uzanır. Uluslu Hamdi Efendi kendi köyü Anduz' dan bahsederken şöyle bir gözlemini aktarmaktadır: "Çiftliğin aşağısından çıkan pınarın suyu tahaccur eder. Buna köfün derler. Bu köfünleri balta ile keserler, ocak vesair binalara sarf ederler ." 
(Çilsüleymanoğlu, 1996:35). Ocakların örüldüğü taşlar arasında bağlayıcı olarak içerisine saman ve kıtık katılan balçıklı çamur harcı kullanılmıştır.

Geleneksel firınların malzemesi de çevrede bol miktarda bulunan düzgün kayran taşıdır. Bir dönem tuğla ocaklarının açılması ile tuğlanın da kullanıldığı örnekler inşa edilmiştir. Ancak bunlar ateşe dayanıklı olmamaları nedeniyle fazla uzun ömürlü olmamıştır.

\subsection{Tuğla-Kiremit}

Kırsal bölgede kiremit örtü 50' li yıllarda bedavra yapımının yasaklanmasıyla birlikte kullanılmaya başlamıştır. Köylerde açılan kiremit ocaklarında yerli, oluklu veya alaturka diye tabir edilen kiremit üretilmiş; üretimin ihtiyacı tam olarak karşılayamadığ temin edilmiştir. Yarım silindir şeklindeki bu kiremitlerin bir ucu diğerine göre daha geniştir, çatıya dışbükey ve içbükey sıralar halinde dizilir.

Özellikle doldurma tekniği ile inşa edilmiş olan evlerde duvar dolgusu olarak kullanılan tuğlalar da yerel üretimdir. Kırsal kesimde tuğla tıpkı kiremit gibi 50' li yıllardan sonra açılan ve Bartın' dan getirilen ustalar tarafından işletilen tuğla harmanlarında imal edilmiştir. Yerli üretim tuğlalar 7x10x30 cm. boyutlarındadır. Yapımı kısaca şu şekildedir: Yaylalardan elde edilen özel balçıklı çamur ağaç kalıplarda sıkıştırılır, güneşte kurutulur ve düzenli bir şekilde istiflenerek harmanda iki gün iki gece, yaklaşık olarak kırk saat kadar odun ateşinde pişirilir. Böylece tuğla kullanıma hazır hale gelir. Tuğlanın duvar örgüsü olarak kullanıldığı örneklerde bağlayıcı olarak kireç-kum harcı tatbik edilmiştir.

Kırsal kesimdeki yerel üretim 60' lı yıllardan sonra fabrika mamulü ucuz tuğla ve kiremitlerin yaygınlaşmasıyla birlikte sona ermiş ve ocaklar kapatılmıştır.

\subsection{Toprak}

Odalarda yer alan ocakların alt kısımlarında yangını önlemek amacıyla ahşap bir döşeme üzerinde toprak dolgu tatbik edilmiştir. Ayrıca gene toprak malzemeden - su ve samanla veya keten çilesi ile karıştırılıp karıldıktan sonra-bağlayıcı olarak da yararlanılmıştır. Karıştırma işlemi akşamdan yapılır, karışım ayakla çiğnenir ve mayalanmaya bırakılırdı. Sabahleyin çamur harç olarak kullanılmaya hazır bir hale gelirdi.

\subsection{Kerpiç}

Kerpiç toprak, su ve samanın karılarak ahşap bir kalıp yardımıyla kesilmesi yöntemiyle oluşturulan bir tür yapı malzemesidir. Esasında bu bölgeye yabancı bir malzeme olan kerpiç, 20. yüzyılda yapı malzemesi kaynağı olarak ormandan faydalanmanın zorlaşması ile kısmen de olsa uygulanmaya başlanmış ve çeşitli müştemilat yapılarının inşasında kullanılmıştır.

\subsection{Kireç}

Özellikle 1950' li yıllardan itibaren kırsal kesime kireç girmiş ve inşaatlarda bağlayıcı olarak kireç kullanılmaya başlanmıştır. Kireç kuyularda söndürülerek ve kumla karılarak özellikle doldurma yapılarda bağlayıcı harç olarak kullanılmıştır. 


\section{Yapı Tekniği}

İnşaat tekniği; kısaca "mekan yaratma sanatı" olarak nitelendirilen mimarlık faaliyetleri içerisinde, bu faaliyeti gerçekleştirmeye yönelik her türlü yöntem, işlem ve yoldur. Tarihsel süreç içerisinde farklı coğrafya, ülke ve iklimlerde farklı gereç, imkan ve yöntemlerle doğup gelişen mimarlık sanatı; geçmişten günümüze kadar sayısız yapı tekniğinin keşfedilmesi, uygulanması ve çeşitli ürünlerle günümüze ulaşması ile aynı zamanda kültür tarihimize de tanıklık etmektedir.

Bartın yöresinde uygulanmış olan ve yüzlerce yıllık deneyim ve bilgi birikimine dayanan geleneksel yapım tekniklerinin en önemli özelliği bu tekniklerin basitliğidir. İklim, bitki örtüsü, jeolojik yapı, tarihsel geçmiş ve sosyal yapı gibi etkenler bu yapım tekniklerinin oluşumu, gelişimi ve farklılaşması konularında yadsınamayacak bir etki göstermiştir. Bölgede yığma ahşap ve ahşap çatkı olmak üzere iki ana yapım tekniği tespit edilmiştir. Ayrıca bu tekniklerin çeşitli varyasyonları ve diğer tali duvar teknikleri de mevcuttur.

Bölgenin karakteristik ve en eski yapı tekniği ahşap yığmadır. Ulus' lu İbrahim Hamdi Efendi Ulus' ta gördüğü ahşap bir camiyi şöyle tasvir etmektedir: “ Bu cami tuhaf bir şekilde ve ahşaptan yapılmıştır. Duvarlarını birbiri üzerine konulmuş ve başları birbirine çatılmış ağaç kirişler teşkil eder.....Bu kadar büyük bir binada tuhaftır bir tek demir çivi ve demire mütealik küçük bir şey dahi yoktur, hepsi de ăgaç çivilerle tutturulmuştur. Bu caminin Osmanlılar devrinden birkaç yüzyıl senelik bir cami olduğu muhakkaktır ." (Çilsüleymanoğlu, 1996:33).

Yığma tekniğinde yapı ahşap hatılların veya kabaca düzeltilmiş kütüklerin köşelerde açılan ve boğaz adı verilen kertikler vasıtasıyla birbiri üzerine bindirilmesiyle oluşturulur. Ayrıca bu hatıllar sübek adı verilen ağaç çivilerle desteklenmektedir.

Bugün kırsal kesimde yer alan bazı konutlarda karşılaştığımız ahşap karkas tekniği bir takım gelişmeler ve ihtiyaçlar neticesinde Bartın kent merkezinden kırsal bölgeye doğru yayılmıştır. Bu yayılım iç kesimlerde çok zayıfken sahil kesiminde ve özellikle Kurucaşile' de neredeyse yığma tekniğinin yerini almıştır. Ormanların bilinçsizce tahrip edilmesi, kesime ve inşaata uygun ağaçların coğrafi olarak daha sapa alanlarda kalması ve 50' li yıllardan itibaren ağaç kesimine ve ahşaba dayalı yapılaşmaya yasal sınırlar getirilmesine başlanmasıyla birlikte köylerde bu teknik yaygınlaşmaya başlamıştır. Tekniğin dağ köylerine dahi yayılmasının tek nedeni ahşap malzeme sıkıntısı çekilmesi değildir, pek çok bölgede ve pek çok örnekte karşılaştığımız kent merkezi ve kasabalardan kırsal alanlara ustaların çalışmak üzere götürülmesi de önemli bir etken olmuştur.Bu teknikte bina ahşap dikme ve kirişlerin demirci yapması büyük çivilerle birbirine çatılması ve bir iskelet oluşturulması yoluyla inşa edilir. Çatkının arası çeşitli şekillerde doldurularak iç ve dış duvarlar meydana getirilir. Bu teknik bölgede dört ana gruba ayrılabilir:
1. Ahşap Kaplama (Kaplama)
2. Ahşap Dolgulu (Slk Doldurma)
3. Bağdadi Sıvalı (Bagdatı) 


\section{Tuğla Dolgulu (Seyrek Doldurma)}

\section{1. İnşaatın Tasviri}

Köylerde inşaat süreci ihtiyaç sahibinin bir usta ile konuşması ve anlaşması ile başlar. Ev sahibi nasıl bir ev istediğini, büyüklüğünü, oda sayısını vs. ustaya anlatır, yevmiye ile çalışması gereken işçi ve usta sayısı tespit edilir. Daha sonra usta ile hane sahibi birlikte evin yapılacağı araziye gider, konuşulanlar doğrultusunda evin şekli ve planı usta tarafından fikren tasarlanır. Usta ile ev sahibi aralarında konuşurken evin büyüklüğü 10x11, 8x9, 10x12, 9x10, 12x14 gibi metrik ölçülerle ifade edilir ve daha sonra evin iç taksimatı bu ölçülere göre düzenlenir. Evin yeri seçilirken tarlaya yakın olması ve kopuk yani heyelan olmayan bir arazi üzerinde olmasına dikkat gösterilir.

İnşaat sırasında kullanılacak her türlü aletin temini ustaların sorumluluğundadır. İnşaat süresince ustalara yemek vermek adettir. Ancak halkın bir kısmı bunu tek öğün (öğlen), bir kısmı ise üç ögün olarak uygulamıştır. İnşaatta çalışmalar sabah namazından sonra (hava aydınlanınca) başlar ve akşam namazından sonra (hava kararınca) biter.

İnşaat başlamadan önce gerekli malzeme inşaat alanına taşınır. Malzemenin kesimine ve taşınmasına yapı ustası karışmaz. Bu malzemenin temini ve inşaat alanına getirilmesi ev sahibinin sorumluluğundadır. Malzemenin tümü ise bir anda getirilmez. İnşaat ilerledikçe, gerektiği kadarı temin edilir ve taşınır. Ana malzemeyi teşkil eden ahşabın kesimi ve kereste haline getirilmesi hızarcılar tarafından gerçekleştirilir; inşaat alanına taşınması ise imece usulü ile yürütülür. Ormanda kesilen, kabuklarından ve budaklarından ayrılan ve dört köşe haline getirilen ağaç kütükleri bıçkı ile kereste haline getirilir. Ağaç bıçkı ile kesilmeden önce çırpılır. Yünden yapılan çırp1 ipi, kırmızı topraktan elde edilen çırp1 boyasına bulanır, tomruğun iki ucundan gerilir. Hızarcılardan biri ipin ortasından çekip bırakır, ağaca hızlıca değen ip üzerindeki boyayı yüzeye bırakır. Bu işlem ağacın kalınlığına göre birkaç defa tekrar edilir. Daha sonra iskele adı da verilen tezgaha alınan ağaç kütükleri hızarla dikdörtgen kesitli elemanlar haline getirilir. Rivayete göre Laz, ağacın çırpılmasını gördüğü zaman “Allah' tan bile doğru” diyerek hayretini ifade etmiş ${ }^{10}$. İnşaat genellikle yağışın azaldığı ve havanın düzeldiği sıcak aylarda gerçekleştirilir ve yaklaşık olarak bir ila iki ay sürer. Kereste haline getirilen ahşap malzeme imeceye katılanlar tarafindan eğer yakın bir mesafeyse omuzlanarak, değilse kenevirden elde edilen kalın halatlarla öküzlere koşularak taşınır. Bazen ağaç ormanda değil inşaat alanında kereste haline getirilir. Ağaçların inşaat alanına taşınmasından sonra inşaatta kullanılacak olan taş malzeme dere yataklarından toplanarak arsaya getirilir. Ev sahibi imeceye katılanlara para değil ama yemek vermek zorunluluğunu taşımaktadır.

Evin yeri seçilirken özellikle kıble göz önünde bulundurulur. Kıbleye karşı inşa edilen evler moderne aletlerin bölgeye girişinden önce yön ve zaman tayininde bölge halkına yardımcı olmuştur. Örneğin cephesi kıbleye karşı çevrilen bir evin batısında gölge kalmadığı zaman vaktin öğlen olduğunu anlamak mümkündür. Ayrıca kar ve yağmurun geliş istikameti, rüzgarın yönü, güneşlenme, manzara gibi faktörler de evin yönelişinde etkili olur.

\footnotetext{
${ }^{10}$ Kaynak Kişi Hüsamettin BİLGİÇ (Müsait Usta).
} 
Tespit edilen gün inşaata başlanır. Önce usta kırnapla arsayı ölçüp evin iç bölüntüsüne göre taksim eder. Bu taksimata göre kazıklar çakılır, kazıklar birbirlerine iple bağlanır. Sonra işçiler temeli kazmaya başlar. Temelin genişliği yaklaşık yarım metredir. Derinliği ise arazinin eğimine ve toprağın cinsine göre değişir. Sert toprağa ulaşana kadar kazmak esastır. Ancak genellikle derinlik bir metreyi nadiren geçer. Temelin pek fazla derin olmamasının nedeni ahşabın hafif bir malzeme olmasıdır. Temel kazısının bitirilmesinden sonra temel taşları yerleştirilir. Bu taşlara miyaz adı da verilmektedir. Köşelerde büyük taşlar, aralarda ise daha ufak taşlar olmak üzere temel taşları yerine yerleştirilir, aralarına çamur ya da toprak konularak örgü muhkemleştirilir. Bazen bu örgüye de gerek duyulmamıştır. Oluşturulan bu temel görünümü ve yapısıyla binadan bağımsız, münferit bir karakter gösterir. Yalnızca eğimli araziyi düzelterek binayı teraziye almak ve ahşap malzemeyi tabanın neminden korumaya yöneliktir. Kırsal bölgede temel atılması işlemi miyazını koyduk deyimiyle ifade edilir.

Temelin bitirilmesinden sonra zemin katın duvarlarının inşasına geçilir. Ormanda ya da inşaat alanında işlenerek dikdörtgen kesitli kereste haline dönüştürülen ve hatıl adı verilen elemanlarla yapının duvarları oluşturulur. Eski evlerin zemin katları yalnızca baltayla düzeltilen tomruklardan inşa edilmiştir. Ustaların bilgi birikimlerinin ve kendilerine olan güvenlerinin artması ve yeni aletlerin elde edilebilmesi ile bu masif tomrukların yerini kalın kesitli hatıllar almıştır. Gene de bu hatıllar üst katta kullanılan ahşap malzemeye göre çok daha kalın ve kaba kalmaktadır. Ancak bu bilinçli bir seçimdir. Üst katta kullanılacak olan hatıllar bıçkı ile daha ince kesitler verecek şekilde yaklaşık 7-8 cm kalınlığında ve itinalı bir şekilde imal edilirler. Ahşap işlerinde lamba ve kiniş kullanılan örnekler de mevcuttur. Alt kattaki ağır hatılları üst üste yerleştirmek ve kenetlemek amacıyla köşelerdeki geçmelerin yanısıra ağaç çiviler de, sübek, kullanılmıştır. Köşelerdeki geçmeleri doğru biçimde yapmak maharet ve sabır ister. Usta kalemle boğaz açlacak yeri işaretler; balta, iğ demiri ve ağaç tokmakla boğazı yani kertiği açar. Hatıllar yerine yerleştirilmeden önce kertiklerin çalışıp çalışmadığı tezgah üzerinde sınanır, denenir. En ufak bir hata duvarın dikliğini, dolayısıyla binanın strüktürünü bozar. Dikliği sağlamak için kullanılan şakül veya terazi her aşamada ustanın yanı başındadır. Alt katta kullanılan boğaza mahalli olarak kertük veya çandu, üst kattakilere ise frengi adı verilmektedir. İkisinin arasındaki en önemli fark üst kattaki geçmelerin daha özenli ve ince olmasıdır. Ustanın kullandığ 1 yapı tekniğinin bölgedeki adı çatmadır. İzah edilen şekilde hazırlanan hatıllar üst üste yerleştirilerek, yani çatılarak duvarlar oluşturulur. Duvarlar yükseldikçe kapı, pencere gibi mimari elemanlar için gerekli boşluklar da birakilir.

Duvar 2-2,5 metre yüksekliğe ulaşınca belleme ve dökme adı verilen büyük taşıyıcı kirişler atılır. 25-30 cm. çapındaki bu taşıyıcı kirişlerin dışında ağır taş ocakların yükünü çekmesi için ocaklık kirişi adı verilen ve 40-45 cm. çapı olan kalın kirişler de kullanılır. Her odanın altında iki ocak kirişi yer alır. Dökme adı verilen kirişlerse her 1 metrede bir “dökülmüş" yani yerleştirilmiştir. Kirişlerin atılmasından sonra üst katın inşasına başlanır, bazen çalışmaları kolaylaştırabilmek amacıyla evin dışına ahşap basit bir iskele kurulduğu da olmuştur. Üst katın duvarları 2,5-3 m. kadar yükselince çatıyı taşıyacak olan üst dökmeler 
atılır. Bu kirişlerin üzerinde, binanın ortasında dört adet dikmeden ve onları birbirine bağlayan boyunduruk tahtasından oluşan bir çatkı oluşturulur. Çatkıyı oluşturan ahşap elemanlar birbirine demirci yapması büyük çivilerle tutturulur. Bu sistem evin çatısını ayakta tutan esas unsur yani evin direğidir. Daha sonra evin dört köşesinden dört tane ağaç direk ki bunlara maha direği adı verilmektedir, kelebelerin üzerine oturtulur ve birbirine bağlanır. Bina mahalandıktan sonra çubuk adı verilen mertekler ile sürme tahtası veya yalnızca tahta olarak adlandırılan kiremit altı tahtaları çakılır ve çatı kiremitle örtülür. Kiremitten önce kullanılan bedavranın yapımı ise şu şekildedir: Balta ile ormana gidilir, çıralı ağaçlardan -örneğin çambir tanesi seçilir, yarma adı verilen bir parça numune ağaçtan kesilir, balta ile ufak ufak yarılır. Eğer ağaç bedavra yapımına müsaitse ağaç yıkılır, hemen orada çalışmaya başlanır. Boyu yaklaşık $1 \mathrm{~m}$., eni 2-3 cm. ve kalınlığı 4-5 mm. olan bedavra tahtaları hazırlanır. Eşeğe yüklenen malzeme inşaat alanına getirilir ve çatının üzerine bindirme yapacak şekilde uygulanır. Çatı inşaatı sırasında kuzgunluk penceresi adı verilen yangın bacası da meydana getirilmektedir. Ayrıca ocakların bacaları için gereken delikler de bırakılır.

Çatının bitirilmesinden sonra evin taban ve tavan döşemeleri ile üst kattaki daraba adı verilen bölme duvarları oluşturulur. Ocak yapımından anlayan bir usta taş malzeme ile ocağı örer. En son olarak da ince marangozluk işleri (oyma nişlerin, dolapların, kapı ve pencerelerin yapılması vs.) gerçekleştirilir. Bunlar da bitirilince ev sahibine teslim edilir.

\section{Yapı ustaları}

Anadolu'nun genelinde olduğu gibi Bartın yöresinde de mimarlık faaliyetlerinde görev alıp yapıcılık işlerini bir meslek olarak icra eden meslek erbabı genel olarak usta olarak adlandirılır.

Kırsal kesimde tespit edilen tüm yapılar gezgin ya da mahalli ustalar tarafından tüm ailenin, akrabaların ve köylülerin de katıldığı imece olarak tanımlanan, ailenin büyüklüğünün, ekonomik durumunun ve özel ihtiyaçlarının da göz önünde bulundurulduğu kollektif bir süreçte inşa edilmiştir. Ortak kullanıma açık yapılarsa tümüyle imece yöntemi ile meydana getirilmiştir. İnşa işini üstlenen ekipte taş işlerini taşçılar, ahşabın işlenmesi ve kereste haline getirilmesi işini hızarcılar evin esas inşa işini ise usta olarak tanımlanan dülgerler halleder. Ameliye işleri için işçiler bulunmaktadır. Bazen tüm bu işleri, yapı sahibinin maddi durumuna bağlı olarak, yapı ustaları kendileri üstlenir. Her grup birbirinden bağımsız bir şekilde çalışır, ancak aralarındaki koordinasyon gerek yaşı, gerek bilgi birikimi ve gerekse deneyimi açısından diğerlerine göre üstün nitelikler taşıyan ve ustabaşı olarak adlandırılan kişi tarafından sağlanır.

Zaman zaman Bartın' dan veya diğer kasabalardan köylere yapı ustalarının getirildiği de olmuştur. (Ulus ilçesi Eldeş Köyünde Bartın’ li mimar Abdi Usta ve Yaşar Yoğurtçu 1934 yılında Molla Yakup ismindeki köy ağasının evini inşa etmişlerdir). Bu gibi olaylar kırsal bölgedeki yerel yapı bilgisini değiştiren, dönüştüren ve geliştiren sonuçlar vermiştir. Yerel mimari bilginin kuşaklar arasındaki aktarımı uygulamaya ve söze dayalı olarak usta-çırak ilişkisi içerisinde gerçekleşmiştir. Orman köylerinde ormanla iç içe yaşamanın getirdiği avantajla insanlar genellikle asker dönüşünde veya askerlikten birkaç yıl önce yapı işlerine 
girişmekte, deneyimli bir ustabaşının yanında temel bilgileri aldıktan sonra (kalem yonmak, kertik açmak, ölçü almak, çatıyı kurmak, şakül ve teraziyi kullanmak) kendileri de usta olarak çalışmaya başlamışlardır. Ancak bu ustaların hemen hiçbirinin geçinmek uğruna yaptıkları yegane iş yapı ustalığıdır. Bunun yanında çiftçilik ve hayvancılığa da devam etmişlerdir. Ustalar yaptıkları işin karşıllı̆ı olarak genellikle yövmiye usulü ile ücretlendirilirdi. Bazen kabala veya kesene olarak bilinen ve yörede inahtar çekmece olarak adlandırılan usul de tercih edilebilirdi. Eğer ikinci usulde anlaşılırsa yapı sahibi hiçbir şeye karışmaz, ustaların ve işçilerin yeme, içme, barınma gibi ihtiyaçları ve yevmiyeleri ustabaşı tarafından karşılanır ve yapı sahibi işin karşılığını işin başında, sonunda veya belirli taksitlerle ustabaşına öderdi. Yövmiye usulü ile anlaşılırsa yapı sahibi inşaat boyunca ustaların ve işçilerin bir öğün yemeğini (öğlen) ve eğer dışardan gelmişlerse yatacağı yeri karşılardı. Çalışma saatleri namaz vakitleri ile (sabah namazından akşam namazına kadar) veya güneşin hareketleri ile (sabah havanın aydınlanmasından akşam havanın kararmasına kadar) belirlenirdi. Haftanın altı günü bilfiil çalışılır, cuma günü ise çalışılmazdı.

\section{Yapı Faaliyetlerinde Kullanılan Aletler}

Ustalarca kullanılan aletler:

- Ayak Keseri: Bir cins büyük keser.

- Balta: Ağaçtan bir sap ve madeni bir ağıdan oluşan kesici alet.

- Balyoz: Temel kazıklarının çakılması sırasında veya ağaç çivilerin ve kertmelerin yerine yerleştirilmesi sırasında ahşap bir altlıkla birlikte kullanılan demir alet.

- Çekiç: Taşın yontulmasıs sırasında murçla birlikte kullanılan demir alet.

- Çırpı Boyası: Doğal kırmızı topraktan ya da kiremit tozundan elde edilen boya.

- Çırpı İpi: Yünün eğrilmesi ile elde edilen ince sicim.

- Çırpı Çanağı: Çırpı ipinin ve boyasının muhafaza edildiği ahşap kap. 20x20 cm. ebadında, dört gözlü bir kaptır. Gözlere su, boya, sünger ve çırpı ipi yerleştirilir.

- Gönye Demiri: Evin ya da evde kullanılan malzemelerin dikliğinin kontrolünü sağlamakta kullanılan demir ya da ahşap alet.

- İğ Demiri/Tıv: Kertiklerin açılması sırasında kullanılan kesici alet.

- Kağnı Arabası: İnşaatta kullanılacak taşların inşaat alanına taşınmasında kullanılan araba.

- Kalem/Arap Kalemi:Bu tabir bildiğimiz kurşun kalemin yanı sıra oyma ve delik açma işlerinde kullanılan madeni bir alet için de kullanılmaktadır.

- Kara Burgu/Burgu: Ağaç çivilerin yerleştirileceği delikleri açmak amacıyla kullanılan delici alet.

- Kara Hızar/Bıçkı: İki kişi tarafından kullanılan büyük testere.

- Keser: Keskin ağzı ile ağaç yonulan madeni alet. 
- Kındap/Kırnap/Kakula: Ölçü almak için kullanılan uzun sicim.

- Küştüre: Küstere. Bir cins uzun rende.

- Madırga: Taş çıkarmak için kullanılan büyük çekiç.

- Mala:Ahşap malzemeden imal edilen, harç ve sıva işlerinde kullanılan yassı alet.

- Manavela Demiri: Taş çıkartmakta kullanılan madeni çubuk.

- Mıh: İnşatta kullanılan demirci yapması 10’ luk 12' lik madeni çivi.

- Murç: Taşın yontulması sırasında kullanılan demir alet.

- Nişangah: Mehengir, nişangir ya da nişangeç olarak tanınan lamba açılması sırasında hatılın kenarına düz çizgi çekmek amacıyla kullanılan alet.

- Palanya: Planya. Tesviye işlemlerinde kullanılan uzun rende.

- Rende: Ahşap elemanların düzgün olmayan yüzeylerini düzeltmek amacıyla kullanılan alet.

- Savul Taşı/Savul Demiri/Şakül: Düşey bir ağırlık -kurşun- ve ipten oluşan binanın dikliğini kontrol etmek amacıyla yararlanılan alet. İp zaman zaman ölçü almak için de kullanılmıştır.

- Su Terazisi: Mimari yapıların dikliğini sağlamakta kullanılan alet ${ }^{11}$.

- Tabla: Karkas yapılarda sıva işlemlerinde kullanılan ahşap eleman.

- Teskere: İnşa malzemesi taşımak amacıyla iki kişi tarafindan kullanılan ve dört tane kolu bulunan ahşap araç.

- Testere: Ahşabı kesmek amacıyla kullanılan bir kenarı dişli madeni alet.

- Tokmak: Ağaç çivilerin yerine oturtulması ve hatıl uçlarında boğaz açılması sırasında kullanılan ahşaptan iri çekiç.

- Zembil: Mısır püskülünden imal edilen ve ustaların aletlerini taşımada kullandıkları küfe.

Bartın' da tespit edilen ve kullananlarca avadanlık olarak de nitelendirilen bu aletlerin tümünün, bütün yapı ustalarınca kullanılması ve bilinmesi söz konusu değildir. Ahşap bir evin yapımı için elzem olan en önemli aletler olan bıçkı, balta, keser, burgu ve şakül her usta tarafindan bilinmektedir. Bu aletlerin bir k1smı bizzat ustalar tarafindan yerel imkanlarla üretilmiş bir kısmı ise kent veya kasabalardan satın alınarak temin edilmiştir.

\section{Geleneksel İmar Kuralları}

Arşiv belgeleri bazı temel kural, kaide ve standartların varlığını gösterse de Türkiye'nin 19. yüzyılda Batılılaşmaya başlamasından ve modern anlamda bir imar hukukunun

\footnotetext{
11 Bugün kullanılan su terazilerinin bölgeye girişinden önce dağ köylerinde şöyle bir sistem kullanılmıştır: Ağaç kesilip kabaca yonulur, bir kenarından bir metre kadar bölümü düzeltilir. Buraya bir parça su dökülür su tam ortada sabitlenene kadar ağacın yüzeyi düzeltilir. (Kaynak Kişi Hüsamettin BİLGİÇ).
} 
oluşumundan önce yazılı bir imar hukuku olup olmadığı kesin olarak bilinmemektedir. Batılılaşma öncesinde Osmanlı coğrafyasında imar ve inşaatla ilgili işler büyük ölçüde kadim gelenekler, geleneksel çözümler ve sözlü hukukla yürütülmekteydi. Bununla birlikte özellikle yapı gereçleri ile ilgili yazılı kurallar ve standartlar mevcuttu (Tuncer, 2002:122). Söz konusu geleneksel hukukun kalıntıları ile bugün özellikle kırsal kesimde karşılaşmak mümkündür. 1882 yılında kabul edilen Ebniye Kanunu yapı çalışmalarını konu edinen en eski yasadır. Ayrıca Cumhuriyetin ilanından sonra 1924 yılında yürürlüğe giren "Köy Kanunu" kırsal kesimdeki yapılaşma faaliyetlerini etkileyen önemli bir etken olmuştur.

Tüm Türkiye'de olduğu gibi Bartın yöresinde de geleneksel bir imar hukuku mevcuttur. Yerleşim yerinin gelişimini ve yapılaşma faaliyetlerini çok da katı olmayan bir düzen içerisinde tutmaya ve birlikte yaşamanın getirdiği bir takım problem ya da husumetleri önlemeye ve çözmeye yarayan bazı temel kural ve kaidelerden müteşekkil olan bu örfi hukuk, ustalarca ya da bizzat yerli halk tarafından nesilden nesile sözlü olarak aktarılmıştır. Sözkonusu hukukun özünü komşuya zarar vermemek ve ortak mülk ya da kullanım alanı olarak kabul edilen bazı sahaları (yol gibi) işgal edecek ya da daraltacak çeşitli müdahalelerden kaçınmak oluşturur.

Örneğin yeni inşa edilecek bir yapının başka bir yapıya çok yakın olarak yerleştirilmesi gibi zorunlu durumlarda komşu ile konuşmak ve iznini almak söz konusudur. Bu tür durumlarda " komşuya zarar vermemek" esastır. Eğer inşa edilecek yapı komşuya zararlıysa (güneşi keserse, saçakları mütecavizse, girişi kapatmaktaysa, damlası diğer eve vurmaktaysa) iki taraf anlaşır, birkaç metre de olsa arazi değiş-tokuşu yapılırdı. Mesele çözülemezse araya köy muhtarı ya da köyün yaşlıları girerek sulh yolunu bulurdu.

\section{Yapı Gelenekleri ve İnşaatla İlgili Geleneksel Uygulamalar}

Bartın ilinde araştırma gerçekleştirilen kırsal nitelikli yerleşimlerde çoğunlukla birbirleriyle örtüşen ve kaynağını Eski Türk inançları ile Anadolu' nun eski kültürlerinden alan inşaatla ilgili bazı geleneksel uygulamalar tespit edilmiştir. Bu uygulamalar temel kazısı sırasında, çatı örtülürken ve eve yerleşirken yapılanlar olmak üzere kabaca üçe ayrılabilir.

Evin yapımı konuşulduktan ve uygun arsa tespit edildikten sonra sira temelin kazılmasına gelmiştir. Kazıya başlamadan önce hoca, ustalar, işçiler, ev sahipleri hep birlikte evin hayırlara vesile olması için dua ederler. İnşaata genellikle Perşembe ya da Cumartesi günü yani kutsal gün olarak kabul edilen Cuma gününden önceki ya da sonraki gün başlanır. Diğer günlerde de inşaata başlamanın bir sakıncası yoktur ancak salı gününün uğursuzluğuna inanılır. Temel kazısına arsa üzerinde sağ taraftan Besmele ile başlanır. Kazı sırasında topraktan kemik çıkarsa evin yerinin değişmesi gündeme gelir. Eğer yapı sahibinin başka bir yerde uygun arazisi varsa evin yeri değiştirilir; yoksa kemikler itinayla toplanıp ayak altında kalmayacakları bir yerde gömülür.

Kurucaşile ilçesi Kömeç köyünde ilginç ve ilginç olduğu kadar da ünik bir "hayırlı arsa arama" uygulaması tespit edilmiştir. Buna göre temelin kazılmasından önceki gece arsaya bir veya iki bardak su bırakılır. Sabahleyin eğer su azalmışsa o arazinin uğursuz olduğuna, hayırlı olmadığına inanılarak evin yapımı için başka bir yer aranır. 
Temel kazısı bitirilince adak olarak bir hayvan kesilir. Anadolu' da inşa edilecek yapılar için Tanrılara adak adama, geçmişi Hititlere kadar uzanan çok eski ve köklü bir gelenektir (Naumann, 1991:65-67). Seçilen kurban küçükbaş ya da büyükbaş olabilir, ancak hayvanın boynuzlarının olmasına dikkat edilir, zira evin tamamlanmasından sonra hayvanın başı eve çakılacaktır. Kurban yapının felaket görmemesi, kaza bela olmaması ve ev sahiplerine hayırlı olması için kesilmektedir. Kesimin törensel bir yanı da bulunmaktadır. Cami imamı, evin malikleri, akrabalar, komşular, ustalar hep birlikte dua ederler, imam Kuran'dan sureler okur, üç kere tekbir getirilir ve temelin sağ köşesinde hayvan kesilir. Kanı temele konulacak ilk taşın yerine ve miyaz kütüğüne sürülür. Bu kanın çiğnenmesi günahtır. Kurban kesildikten sonra hemen soyulur, parçalanır, et kemiklerinden ayrılır, hayvanın yenmeyen bölümleri ile birlikte kemikler kurbanın kesildiği kuyuya veya ayak altında kalmayacağı bir yere gömülür. Daha sonra et büyük kazanlarda pişirilir, pilavla birlikte tüketilir. Gelenlere tatlı dağıtılır. En son olarak evin hayırlı olması için tekrar topluca dua edilir.

Temel kazısı sırasında gerçekleştirilen bir başka uygulama da temele devrin madeni paralarından bırakılmasıdır. Bu para eve uğur, bolluk bereket getirmesi için ve mülkiyeti simgelemesi amacıyla atılmaktadır.

İnşaat sırasında eğer işçilerden veya ustalardan birisi yaralanır ya da ölürse orada bir uğursuzluk olduğuna inanılır. Bu uğursuzluktan kurtulmak için de gene kan akıtılır, yani kurban kesilir.

Evin yapımı esnasında (temel taşları veya hatıllar yerine yerleştirilirken vs.) ustalar ev sahibinden küçük bahşişler koparabilmek amacıyla çeşitli uygulamalar gerçekleştirir. Örneğin "taş kalkmiyor", "araba devrilmiyor", testere kesmiyor", "balta yonmuyor" gibi sözler söyleyerek işi bırakırlar ve ev sahibi onlara cüzi bahşişler veya sigara vererek çalışmaya devam etmelerini sağlar.

Çatı iskeletinin yapımı sırasında omuzluk ağaçları birbirlerine çivilenirken usta "çivi buraya geçmiyor" diyerek keseri bir kez daha bırakır. O zaman yapı sahibi ustalara sigara dağıtır, eğer bu yeterli olmazsa onlara bir tavuk alacak kadar para verir. Çatı konstrüksiyonu bittikten ve sıra kiremitlerin örtülmesine geldikten sonra ustalar baş omuzluğa bir sırık çiviler ve onun üzerine bayrak veya bayrak işlevi görebilecek bir bez asarlar. O bayrak hem evin kimliğine bir göndermedir (Kentte mübadele öncesinde yaşayan gayrimüslimlerin kendi inşaatlarına inanç ve kökenlerini belirten işaret veya bayraklar astıkları söylenir) hem de binanın selamete erdiğine işarettir. Bayrağın asılmasından sonra önce ev sahipleri, daha sonra da komşular ve akrabalar ustalara hediye etmek üzere entari, peşkir, mendil, basma gibi dokuma türünden şeyler getirirler ve ustalar da bunları o direğe asarlar. Bahşiş, öndül, hediye gibi çeşitli isimler verilen bu dokumalar akşam iş bitimiyle ustabaşı tarafından tüm çalışanlara eşit bir şekilde pay edilir.

Ev tamamlandıktan sonra ustalar, işçiler yapı sahibiyle helalleşir. Eve genellikle perşembe günü taşınılır. Eve taşınıldığı akşam ustaların ve komşuların da katıldığı küçük bir tören yapılır, evde Kuran ve Mevlid okutulur. Bazen ev için kesilen kurbanın temelde değil eve taşınılmasından sonra gerçekleştirildiği olur ve aynı şekilde ziyafet türü bir yemekle 
kurbanın eti tüketilir. Zengin yapı sahipleriyse hem inşaatın başında hem de sonunda kurban kesip dağıtır.

Yeni yapılan evi görmeye gelmek de bölgede karşılaştığımız yaygın bir uygulamadır. Ziyarete gelenlerin hediye getirmek zorunda değildirler ancak genellikle evin küçük bir eksiğini giderecek şekilde küçük bir hediye getirilir.

\section{Konutla İlgili İnanışlar}

İnsanın doğduğu, büyüdüğü, tüm hayatını geçirdiği ve öldüğü evin halk kültürüne olan derin etkisini günlük hayatla ilgili hemen her konuda özellikle halk inanışlarında tespit etmek mümkündür. Bu inanışlarda evin kendisinin ve onu oluşturan ocak, eşik vs. gibi elemanların kutsallaştırıldığı hatta tabulaştırıldığı gözlemlenebilir. Ateşin ve ocağın inanç boyutuyla gerek Anadolu' nun arkaik çağlarında ve gerekse Türk kültür tarihinde önemli bir yer tutması ve mukaddes olarak kabul edilmesi olgusu karşılığını Bartın ve çevresinde de bulmuştur. Ocağın evin büyüğü tarafından yakılması, kirletilmesine karşı kesin yasaklar konulması, külüne basılmaması, cuma ve bayram gibi özel günlerde bazı yiyeceklerin kokutulması, ateşinin suyla söndürülmemesi ve sacayağın boşken ters çevrilmesi gibi ilginç uygulamalar hep bu kutsallığı vurgulayan, çoğunlukla gerçek anlamını kaybederek gelenekselleşen, insanların bilinç altına kazınmış ve bazen dinsel bir kılıfa sokulmuş davranış biçimleridir. Bu bağlamda evde yalnızca ocak kutsallaştırılmamıştır. Örneğin dış dünya ile ev içerisinde sürdürülen özel hayatı ve mülkiyeti birbirinden ayıran en net çizgi ve sınır olan kapı ve eşikte de kutsallaştırma ve hatta tabulaştırma kaygısını görmek pekala mümkündür. Eşikten bir takım özel hareket ve sözlerle (Besmele çekilmesi ve sağ ayağın kullanılması) geçilmesi bu sınırı vurgulayan en karakteristik uygulamadır. Bölge halkı eşikte oturan insanları uğursuz ya da düşman olarak görür, bu insanların başına bir bela geleceğine, kısmetinin kesileceğine inanır, kapı arkasında her an insanlara zarar verebilecek cin veya perilerin bekleştiğini düşünür. Yeni gelinin evin eşiğine yă̆ sürmesi ise gelinin eve ve aileye yă̆ gibi sımsıkı yapışması dileğini vurgulamaktadir.

Aşağıda bölgede gerçekleştirilen araştırma esnasında tespit edilebilen inançların bir özeti verilmiştir:

- Altında mezar olan ev uğursuz sayılır, malın ileri gitmeyeceği (artmayacağı) ve mevtanın ev halkını rahatsız edeceği düşünülür(Eldeş Köyü, Yukarıdere Köyü).

- Eve karınca üşüşmesi uğurludur. (Zafer Köyü)

- Evde yılan görülmesi uğursuzluğa işarettir. Çünkü insanla yılan birbirlerine kinlidir. (Zafer Köyü)

- Evin yakınlarında köpek ulursa veya kuku kuşu öterse evden birisi ölür. (Yukarıdere Köyü)

- Gece rüyada evin yıkılmasını ya da yanmasını görmek uğursuzluğa, evden birinin ölmesine işarettir. (Zafer Köyü, Yukarıdere Köyü) 
- Evden birisi ölürse ölünün ruhu bulaştığı için kaldığı odadaki her şey yıkanmal1, temizlenmelidir. (Zafer Köyü)

- Sabah güneş doğmadan evin kapısının önünde sağ tarafta melaikeler, sol tarafta Şeytan bekler. Kapı erkenden ve Besmeleyle açılırsa Melek evin o günkü nasibini verir. (Zafer Köyü)

- Temizlenmeyen, pis evlere cin peri gelir, bulaşıklar yıkanmamışsa onu yalarlar (Zafer Köyü).

- Evde durup dururken ayna kırılması uğursuzluğa işarettir. (Özbaşı Köyü, Yukarıdere Köyü)

- Sacayağın üstü ocakta boş bırakılmaz, işi bitince -yorulduğu için- kaldırılır. Boş bırakılırsa ölü suyu 1sınır. ( Zafer Köyü, Yukarıdere Köyü, Uğurlu Köyü, Özbaşı Köyü, Eldeş Köyü).

- Ocaktan alınan kül herhangi bir yere, ayak altına değil; yemişin dibine, bahçenin kenarına ya da dere kenarına dökülür. Küllüklerde cin peri tayfası eğleşir. Külün üstüne basılırsa (üyük derler) cin peri zapt eder ( Zafer Köyü, Yukarıdere Köyü, Uğurlu Köyü, Eldeş Köyü, Özbaşı Köyü).

- Ocaktan çıkan küle tükürülmez, çünkü peygamber ekmeğini ona banıp yemiştir. (Özbaş1 Köyü)

- Kıtlık zamanında bir kadın aç çocuklarını ocak külünden yaptığı ekmeklerle kandırmış, bu yüzden kül nimet sayılır. (Uğurlu Köyü)

- Ocaktaki ateş suyla söndürülmez, külle kapatılır (Eldeş Köyü).

- Ocaktaki ateşi suyla söndürmek gerekirse “ev sönmesin” diye “değirmen ocağına döküyorum” diyerek su dökülür. (Yukarıdere Köyü)

- Evin ocağını evin gelini yakar. (Zafer Köyü)

- Ocaktan Cuma günleri kül alınmaz, günahtır. (Aşağı Çerçi Köyü)

- Bayramlarda, kandillerde veya Cuma akşamları ocakta un helvası yapılır, bir parça da ocağa atılarak kokutulur. Çünkü ölülerin ruhu bacanın ağzına gelip beklermiş. (Eldeş Köyü, Yukarıdere Köyü)

- Ocakta soğan kabuğu yakılırsa, yakan kişi fakir olur (Zafer Köyü)

- Ocağa tırnak atılmaz, canlı sayılır, günahtır. (Eldeş Köyü, Zafer Köyü, Yukarıdere Köyü, Aşağ1 Çerçi Köyü, Özbaşı Köyü).

- Ocağa saç atılmaz, canlı olduğu için günahtır. (Aşağıçerçi Köyü)

- Ocağa veya çıraya tükürülmez, mekruhtur, tüküren fakir olur(Eldeş Köyü, Zafer Köyü).

- Çıra tükürülerek söndürülmez. Çünkü çıra güzel kokar, güzel kokmasının nedeni Peygamberin terinden meydana gelmesindendir (Zafer Köyü) 
- Ateş kutsaldır, çünkü her şeyin son geçidi ateştir, o insanlara verilen bir nimettir. Ateşe tükürülmez, günahtır. Ateş bir nurdur. Ekmek ateşten geçtiği için, ondan kurtulduğu için bir nimettir, üzerine basılmaz (Uğurlu Köyü, Zafer Köyü, Özbaşı Köyü).

- Ocağın yanında yatmak iyi sayılmaz, buralarda cin peri tayfası gezinir (Zafer Köyü).

- Tuvalet altlarında, evlerin saçak altlarında, küllüklerde, değirmenlerde ve köprü altlarında cin peri tayfası gezinir (Zafer Köyü)

- Akşam namazından sonra evden ateş verilmez, çocuk uyuyamazmış. (Özbaşı Köyü)

- Akşam namazından sonra evden ateş, maya, tuz verilmez; evin bereketi gider. Yukarıdere Köyü)

- Akşam namazından sonra evden yoğurt vermek gerekirse üzerine odun kömürü atılır, evin bereketi kaçmasın diye. (Yukarıdere Köyü)

- Tuvalete sol ayakla girilir, sağ ayakla çıkılır (Eldeş Köyü, Yukarıdere Köyü, Özbaşı Köyü, Zafer Köyü)

- Tuvalette konuşanın ölürken dili tutulur (Zafer Köyü).

- Tuvalete tükürülmez, tüküren insana Şeytan can verirken kendi tükürüğünü içirir (Zafer Köyü)

- Tuvalette, banyoda fazla kalınmaz. İnsanı koruyan melaikeler pis kokulu yerlerde durmayı istemedikleri için incinirler. (Zafer Köyü).

- Evin eşiğinden sağ ayakla girilir, sol ayakla çıkılır (Eldeş Köyü, Özbaşı Köyü, Yukarıdere Köyü, Zafer Köyü)

- Yeni gelin evin eşiğinden geçerken kucağına çocuk verilir, yumurta yedirilir çok çocuğu olsun diye. Eşiğe yağ sürdürülür yağ gibi geçinsin diye, bal sürdürürler yağ gibi yapışsın diye. (Yukarıdere Köyü, Zafer Köyü)

- Eşiğe oturmak uğursuzluktur, iftiraya uğrar, dedikodusu olur, eşiğe çingene oturur, fakirliğe işarettir. (Eldeş Köyü, Aşağı Çerçi Köyü, Özbaşı Köyü, Yukarıdere Köyü, Uğurlu Köyü, Zafer Köyü)

- Eşiğe oturulmaz, oturulursa melekler eve giremez. (Yukarıdere Köyü)

- Yeni gelinin kötü huyları babasının evinde kalsın diye eşikten geçerken eteği silkelenir. (Mamak Köyü)

- Kırk suyu tuvalete dökülmez ağaç diplerine, çantı dibine veya ayrı kanallara gittiği için abdestliğe dökülebilir. Kırk suyu kaşıkla evin duvarlarına serpiştirilir, evde temizlik olur, bu yapılmazsa uğursuzluk olur. (Eldeş, Yukarıdere Köyü, Uğurlu Köyü)

\section{Mimari ve Nazar İnancı}

Bölgede evi ve içerisinde yaşayan maliklerini nazardan korumak amaciyla uygulanan en yaygın pratik kesilen hayvanların veya av hayvanlarının başının veya boynuzlarının evin 
çatmalarına ya da kapıların üzerine çakılmasıdır. Ayrıca gene nazara karşı atnalı, kurbağa ölüsü, kaplumbağa kabuğu, yumurta kabuğu, ayakkabı, çarık, muska, gökboncuk ve sarımsak da kullanılır. Evin içerisine veya giriş kapısının üzerine Besmele ya da Maşallah gibi yazıların yazılması da söz konusudur. Kurucaşile' de tespit edilen ilginç bir uygulama omuzluk ağacının altına çakılan bir çiviye tavuk pisliği, köpek tüyü, sarımsak kabuğunun karıştırılıp bir beze sarılarak asılmasıdır. Buna benzer bir uygulama ahır için de gerçekleştirilir: Buna göre köpek tüyü, sarımsak kabuğu ve katran karıştırılarak bir beze sarılır ve ahırın üzerindeki kirişlerden birine asılır.

\section{Sonuç}

Aile toplumsal örgütlenmenin ve toplumsal kurumlaşmanın temel işlevsel bir oğesi ve çekirdeğidir (Kır, 2011:381). Aile yapısı ve ailevi ilişkiler toplumsal yapı ile gerek somut ve gerekse somut olmayan kültürün oluşumunda temel argümanlardandır. Bu bağlamda mimari çevrenin oluşumu, gelişimi ve değişimi konusunda ailenin ve aile yapısı ile yaşam kültürünün etkileri son derece önemlidir. Aile yapısının mimari üzerindeki etkileri -kent ortamına görekırsal çevrelerde daha güçlüdür. Kırsal bölgede mimari eserlerin tasarım ve inşa sürecine ailenin katılımının daha etkin ve yoğun olması bu durumu beraberinde getirmiştir.

Bartın yöresi kırsal yerleşmelerinde yakın zamanlara kadar geleneksel geniş aileler toplumsal yapıya hâkim aile tipini teşkil etmiştir. Bununla birlikte yirminci yüzyılın son çeyreğinden itibaren teknoloji, ulaşım ve iletişim alanındaki gelişmeler, eğitim seviyesinin artması, göç hareketleri, sosyo-ekonomik değişim nedeniyle hızlı bir çözülmeye uğrayan bu yapının yerini -geleneksel ilişkilerin de tümüyle dışlanmadığı- geniş aile ile çekirdek aile arasında bir geçiş aile modeli almaya başlamıştır. Küçülen, tarım ve hayvancılıktan uzak kalan aile üreticiden çok tüketici bir mahiyet kazanmıştır.

Sosyo-kültürel yaşam ve aile yapısının evrilerek geçirdiği değişim bölgeye has kırsal mimariyi de değiştirmekte ve dönüştürmektedir. Ailelerin tarımcı hüvviyetlerini kaybetmeye başlaması geleneksel üretim tarzı ile ilintili bazı mimari yapıların tümüyle işlevsiz kalarak terkedilmesi sonucunu vermiştir. Bu bağlamda su değirmeni, fırın, ambar, samanlık gibi yapılar büyük ölçüde kullanım dışı kalmıştır.

Kırsal mimarideki değişimi en bariz şekilde konut mimarisinde müşahede etmek mümkündür. Zira konut mimarisi içerisinde yaşayan aile ile birlikte düşünülmesi gereken bir olgudur. Aile büyüklüğ̈̈, ailenin sosyo-ekonomik statüsü, ailenin yapısı, aile bireylerinin sosyal yaşamda ve dolayısıyla aile içinde oynadığı roller, ailenin yaşam sürecinin hangi aşamasında bulunduğu, ailenin toplum ve toplulukla kurduğu ilişkiler, ailenin değer ve tutumları, ailenin doğrudan konut kullanımına yönelik normları, ailenin beklentileri konut örgütlenmesinin en önemli belirleyicileridir (Zeylan, 2009:98)

Araştırma bölgesinde sosyolojik olarak geniş ailenin küçülmesi ve aile üyelerinin azalması göreceli olarak yeni inşa edilen evlerin küçülmesi ve evi oluşturan mekân sayısının azalmasına neden olmuştur. Geleneksel konutların zemin katları genel hizmetler, depolama gibi amaçlarla kullanılmışken yeni inşa edilen konutların zemin katları yaşama odaklı olarak dizayn edilmektedir. Geleneksel kırsal konutları oluşturan odalar uyuma, yatma, oturma, 
misafir ağırlama, toplanma, yemek yeme, yıkanma gibi ihtiyaçları karşılayacak şekilde çok fonksiyonlu olarak tasarlanmışken modern konutlarda bu fonksiyonlar ayrı mekânlara (banyo, oturma odası, misafir odası, çocuk odası, salon vb.) dağıtılmıştır. Bağımsız banyo, mutfak gibi yeni ve şehirli mekânlar yeni konutların tasarımına girmiştir. Sofa mekanının yerini salon almıştır. Geleneksel mimaride uygulanmış olan insani oran ve ölçüler (pencere, sedir, dolap yükseklikleri gibi) modern yapılarda pek düşünülmemiştir. Ayrıca pencere ve kapı boyut ve şekli gibi mimari ayrıntılarda da -kullanılan inşaat malzemesinin zorlamasıyla- büyük değişiklikler vardır. Ev içi döşemlerin ve eşyaların -günlük alışkanlıkların değişmesine koşut olarak- değişmesi ve modernleşmesinin (örneğin geleneksel yaşamda mekanın ortasında kurulan yer sofrasının yerini yemek masasının almaya başlaması, sedirlerde ya da yerde bağdaş kurarak ya da diz çökerek yastık yardımıyla oturulurken oturma takımları ve koltukların kullanılır olması, yer yataklarının yerini yataklar ve yatak odalarının alması) yanı sıra mimari öge ve mekânlara ilişkin terminoloji de yenilenmiştir. Modern evlerde geleneksel evlerin ilk inşasında bulunmayan atık su, temiz su, elektrik tesisatı, 1sıtma sistemleri, aydınlatma ve havalandırma tertibatı mutlaka yer almaktadır. Kent ortamından yeni yaşam kalıplarının devşirilmesi yeni mimari ögeleri de beraberinde getirebilmektedir (balkonbarbekü gibi). Genel olarak konutlar kırsal karakterini kaybedip şehirli bir görünüm kazanmaktadır.

Aile yapısındaki değişim mimari olarak yukarıda bahsedilen dönüşüme neden olduğu gibi mevcut geleneksel konutların da bir şekilde elden geçirilmesine neden olmuştur. $\mathrm{Bu}$ bağlamda iç mekânlarda da bir takım değişiklikler yapılarak (duvarların kaldırılması vb.) yeni kullanımlara kapı açılabilmektedir. Geleneksel konutların çok işlevli odaları modern mobilyalarla düzenlenerek özelleştirilmiş, oturma odası, yatak odası vb işlevlere sahip mekânlara dönüştürülmeye çalışılmıştır. Odalarda yer alan gusülhanelerin ve ocakların kullanımı neredeyse tümüyle sona ermiştir.

Alan araştırmaları sonucunda il genelinde halk mimarisi ürünlerinin hızla yok olmaya yüz tuttuğu hatta bazı bölgelerde tamamen yok edildiği gözlemlenmiştir. Kırsal kesimdeki mimari değişim ve dönüşümle birlikte ahşap evler, ambarlar, samanlıklar, köyodaları vs. sökülerek fırın sahiplerine cüzi bir para karşıllğında satılmakta; bir toplumun kültürü, bilgi ve becerisi bir avuç bozuk para uğruna ekmek ateşi olmaktadır. Sayıları çok azalmış olan yapı ustaları ise artık yaşamayan eski bir zanaatın son mirasçılarıdır. Kırsal kesimde halk mimarisi ve mimarlık bilgisi yok olmak üzeredir. Ancak bugün dahi inşa faaliyetleri büyük ölçüde yerel yapı ustaları eliyle gerçekleştirilmekte ve ustalık geleneği modern çağa ayak uydurarak bir şekilde kendisini devam ettirmektedir.

\section{YEREL MIMARİ SÖZLÜK :}

Halk mimarisi olgusunun Anadolu coğrafyasının faklı bölgelerinde, farklı şartlarda yeşerip gelişmesinin getirdiği zenginlik ve çeşitlilik, yapı ve yapı sanatı ile ilintili terimlerde de yeknesak bir düzenin oluşmasını engellemiş, aynı veya benzer ögelerin değişik bölgelerde değişik sözcüklerle ifade edilmesi neticesini doğurmuştur. Bartın ilinde de mimarlıkla ilgili yöreye özgü bir kavramlar silsilesi mevcuttur.

Afur: Ahırda ineklerin yem yediği ahşap yemlik. 
Ağaç Oda: Köy odasi.

Akım: Çatı eğimi.

Apteslik Yannı: Sofanın köşesinde abdestlik, hela ve mutfak raflarının bulunduğu 1,52 metre genişliğinde alan.

Aralık: Sahil kesiminde sofa.

Ara Yer: İki oda arasına yerleştirilen ve ses izolasyonu sağlayan dar koridor. Ayrıca bu koridor vasıtasıyla sofadan sergü adı verilen mekana ulaşılır.

Arka: Kömeç köyü ve çevresinde tespit edilen evlerin rüzgar, kar ve yağmura diğer cephelere göre çok daha fazla maruz kalan cephesinde uygulanan (kuzey cephe) ve bu cepheyi ikinci kez saran diş kaplama, üveyik kanadı şeklindedir.

Armoz: Hatılların birbirlerine bitiştirildiği yan yüz.

At Damı: Köyodalarının zemin katlarında yer alan ahır bölmesi.

Baca: Ocak.

Baca Sövesi: Ocakların iki dik kenarı. Söveye tutturulan demir bir halka aydınlanmada kullanılan çıranın yerleştirildiği alandır.

Baltacuk Ayarı: Değirmenlerde suyun gelişini ayarlayan ya da tümüyle kapatan ahşap musluk sistemi.

Battal Ağaç: İnşaat işlerinde kullanılan büyük ve işlenmemiş ağaç, tomruk.

Battal Taş/Koca Taş: Temelde çatmaların altına ya da dikmelerin altına gelecek şekilde yerleştirilen büyük ( birkaç yüz kg ağırlığında) temel taşı.

Bedavra : Çam, kestane veya köknar ağaçlarının balta ile yarılması yöntemiyle elde edilen ahşap elemanların çatı üzerine kaplanmasıyla gerçekleştirilen örtü. Kalınlığı $1 \mathrm{~cm}$, genişliği 3-4 cm, uzunluğu ise $50 \mathrm{~cm}$ olanlara yarma, kalınlığ $2-3 \mathrm{~cm}$, genişliği $15-20 \mathrm{~cm}$, uzunluğu ise 3-5 m. olanlara ise tahta adı verilir.

Belleme: Odaların altında dökmeden büyük taşıyıcı kiriş. Sayısı evin büyüklügüne göre 3 ile dört arasında değişir. 30x20cm. ebatlarındadır.

Buğar: Pınar, çeşme.

Cilit: Çiğ tuğla ile inşa edilen ambar ve samanlık gibi yapılarda kullanılan yatay ahşap elemanlar, hat1l. 1-1,5 metreyle birakilır.

Çamur: Bağlayıcı olarak kullanılan balçıklı toprak. Çatlamasını önlemek amacıyla çamurun içine genellikle saman bazen de keten çilesi katılır, suyla karılarak mayalanması için bir süre bekletilir, daha sonra uygulanır.

Çandu/Çandı Kesme/Çinti: Kabaca yonulmuş tomrukların köşelerdeki yarım boğazlar vasıtasıyla üst üste oturtulması yöntemiyle oluşturulan yı̆̆ma yapı. Ayrıca yapıların köşelerinde yer alan geçmeler de bu isimle bilinir. 
Çardak: İç kesimde odalar arasında yer alan ve sofa işlevi gören geniş hacim.

Çatı Dikmesi: Çatıyı ayakta tutan ahşap direkler. Dikmeler oynamamaları için ayıbacaklarıyla desteklenmiştir.

Çatı Ev/Doldurma Ev: Ahşap çatkının arasının tuğlayla doldurulduğu, karkas yapı. "Çatı" kelimesi, birbirine çatılmış, çakılmış şeylerin topu anlamına gelmektedir ${ }^{12}$.

Çatma: Ahşap yığma yapı ve bu yapının köşelerindeki geçmelerin bütününe verilen ad (Çatma başı, çatma dibi).

Çember/Băg Ăgacı: Karkas yapılarda direkleri dört taraftan yatay olarak bağlayan ahşap kirişler. $\mathrm{Bu}$ ağaçlar birbirlerine dört köşede dam kertisiyle bağlanır. 10x10 cm. ya da 10x12 cm. ebadındadir.

Çevürge/Çövürge/Çökürge: Evlerin iç mekanında yer alan kapılarda, pencerelerde ve dolaplarda kullanılan ahşap kapı mandalı.

Çırpmak: Ahşap elemanları kesime uygun şekilde işaretlemek.

Çörtle/Çörte: (1)Hamam dolabı ve abdestlikde oluşan atık suyu evden dışarı atmayı sağlayan çam veya meşe ağacından oyulan oluk. (2)Su kaynaklarından çeşmelere su getirilen ahşap oluk.

Çubuk: Bedavraların üzerine yerleştirildiği mertekler.

Dakma/Takma: Mertek. 10-12 cm. çapındadır. Uzunluğu çatının eğimine göre değişir.

Dam/Tam: Ahır. Genellikle her evde zemin katta iki tane ahır bulunur; bunlardan birisi öküz tamı, diğeri ise inek tamı olarak adlandırılır.

Damaltı: Zemin katta ahırın ahşap kaplamalı tabanı ile toprak yüzeyi arasında kalan ve eğimden kaynaklanan boşluk. Bu boşluk genellikle kümes olarak değerlendirilmiştir.

Dam Kertisi/Düz Kerti/Domuz Damı Kertisi: Konutların zemin katlarında kullanılan kaba geçmeler.

Daraba: (1)Ahşap malzemeden bahçe çiti. (2)Yapıların iç mekanlarında yer alan bölme duvarları. Kalınlık yaklaşık 1,5 santimdir. Daraba tahtalarının uzunluğu koğuşlara göre daha kisadır.

Direk/Dikme: Ahşap karkas yapılarda kullanılan 10x10 cm boyutlarında ve 3 metre yüksekliğinde ahşap dikmeler.

Direkbaşı/Başlık: Karkas yapılarda direklerle çember ağaçları arasına yerleştirilen ve kolona etki eden basıncı azaltmak amacıyla kullanılan çok sert ağaçlardan imal edilen tepelik. $50 \times 50 \times 15 \mathrm{~cm}$. ebatlarındadır

Direkbaşı Arası Doldurma: Ahşap çatkının arasının tuğla veya çiğ tuğla ile doldurulması yöntemi.

${ }^{12}$ Hasol, 1990: 126 
Dökme/Atma: Zemin katla birinci kat arasına 1 metre arayla atılan, dökülen, taşıyıc1 ağaç kirişler. 15-20 cm çapındadır.

Döşek: Kısa kenarı yaklaşık $3 \mathrm{~cm}$, uzun kenarı 10-12 cm olan taban döşemesi tahtası.

Eğmeç: Ocağın altında ocaklık kirişinin üzerinde temellerin ve dolgu toprağının yerleştirildiği ahşap taban, ocak kaidesi.

Epteslik: Abdestlik. Abdest alınan, bulaşık yıkanan, el yüz temizliği gerçekleştirilen ve hatta kışın çamaşır yıkanan ahşap tezgah. Tezgahın altında yer alan dolaplarda ve üstünde yer alan raflarda mutfak malzemeleri ve su güğümleri de muhafaza edilir. Bu kısmın dış kaplama tahtaları diğer alanlara göre daha seyrek çakılmıştır ve havalanması gerektiği için -kuzeyden esen rüzgar düşünülerek- genellikle kuzeye çevrilmiştir.

Göbek: Ahşap tavanların ortasında yer alan süslü alan.

Göbek Taşı: Tavşut fırınlarının örtüsünde üstte en ortaya konulan yuvarlak biçimli taş.

Gönyesine Getirmek: Yapının köşelerini gönye yardımıyla dik açıyla birleştirmek.

Hamam Dolabı/Gusülhane: Odalarda ocağın yanında pencere tarafında yer alan yıkanma dolabı. Ayrıca yüklük işlevi de görür. Burada ocakta isıtılan su kenarda yer alan rafın üzerine yerleştirilir ve küçük bir tasla taburelere oturularak yıkanılır, yıkanma işleminden sonra içerisinde bulunan ahşap dolap kapatılır, yatak yorgan tekrar buraya konulur. İçerisinde oluşan atık su ahşap borularla dışarı atılır.

Hambar: Ambar.

Hambar Çardağı: Ambar girişinin önünde yer alan üç yönden açık çıkıntı.

Hambar Gözü: Kandilleri üç yönden çeviren ahşap bölmeler.

Hambar Kandili: Ambarlarda depolama amacıyla kullanılan derin bölmeler.

Hatıl: Ahşap yığma yapılarda duvarları oluşturan dikdörtgen kesitli ahşap elemanlar. Kısa kenarı zemin katta 6-8 cm, üst katta 4-5 cm,uzun kenarı 25-30 cm, uzunluğu 4-5 metredir.

Hela/Kenef/Ayakyolu/Apteshane: Tuvalet.

Hergil/Helgir: Konutlarda kullukta yer alan dikdörtgen prizma, üstten kapakl1, içerisinde bölmeleri bulunan, lambalı tahtalarla imal edilen zahire deposu.

Hücre/Fecre/Gözgere/Galeve: Ocağın yanında yer alan ve genellikle kahve takımlarının ve aydınlatma araçlarının muhafaza edildiği kapaksız nişler.

Işsıkık/Parmaklık/Nefeslik: Kulluk kısmının cephelerinde yer alan hava ve 1 şık girmesi için kullanılan parmaklıklı dikdörtgen boyutlu küçük açıklık.

İnahtar Çekmece: İnşaat işlerinde uygulanan kabala ya da kesene olarak da bilinen bir çeşit ihale usulü. İnşaatın maliyeti usta tarafından çalışmanın başında toptan ya da taksitler halinde alınır ve bundan sonra yapı sahibi hiçbir şeye karışmaz. 
İskele: Dik merdiven.

İskelet: Karkas yapılarda ahşap çatkı.

İspanyol Örtü: Kırsal kesimde ellili yıllardan sonra yaygınlaşmaya başlayan, saçakların oldukça geniş tutulduğu örtü biçimi.

Kabak Gitmek: Ahşap yığma evlerde ikinci katın dış duvarları oluşturulurken abdestlik kısmını evin cephesinden hafifçe dışarı taşırmak.

Kafa: Mahya ağaçlarının saçaklardan dışarıya taşan fazlalığı.

Kalem Çekmek: Kalemle hatılların uç kısımlarındaki boğaz yerlerinin işaretlenmesi.

Kalem Yonmak: Kertiklerin açılması.

Kaplama Ev: Ahşap çatkının dış yüzeyinin kereste çakılarak kapatıldığı yapı. Yağmurun vurduğu cephelerde kaplama üveyik kanadı şeklinde, diğer cepheler ise lambalı olur.

Karaltı: Kızak ve arabaların muhafaza edildiği basit yapı.

Kara Duvar/Kara Yapı/Kara Bina/ Kasnak Yapı: Ahşap yığma tekniğiyle tomruklarla veya hatıllarla- inşa edilmiş her tür mimari eser. Bu tip yapıları inşa edebilecek kabiliyet ve bilgiye sahip kişiler kara yapı ustası olarak adlandırılır.

Kara Duvar Örtüsü: Saçakların daha dar tutulduğu ve bölgenin geleneksel örtü biçimini teşkil eden örtü biçimi.

Karga Dili/Firengi Geçme/Firengi Çatması: Evlerin üst katlarında kullanılan ince kesitli geçmeler. Tam kerti.

Kasnak Tahtası: Hatıl.

Kayran: Çürüksü, dayanıksız, yumuşak taş.

Kayranlı Toprak: Kıraç, taşlık yerlerde bulunan, çamur yapmaya elverişli olmayan toprak cinsi.

Kelebe Bonduruğu/Kandil Bağı/Kar Bağı: Kelebe direklerini birbirine bağlayan dört adet kirişten her birine verilen ad.

Kelebe Direği/Buğa Direği/Hamal Ağacı/Kafes Dikmesi/Baba Direği: Oturtma çatılarda, çatıyı ayakta tutan dört tane ahşap direkten her birine verilen ad. $15 \times 15 \mathrm{~cm}$ ebatlarında 2-2,5 metre yüksekliğindedir.

Kelevet: Kerevet.

Kenef/Hela/Memişhane/Ayakyolu: Tuvalet.

Kepenge: Pencereleri dişardan kapatmaya yarayan ahşap kapak.

Kertik: Ahşap hatılların uç kesimlerinde açılan çentik, boğaz.

Kertme: Boğaz açma faaliyeti. 
Kıtık: Bağdadi sıvasına ve çamur harcına katılan 1-2 cm. boyunda kıyılmış keten.

Kibritlik: Fırınların dış cephesinde yer alan küçük niş.

Kiler Dolabı/Danalık/Kuzuluk: Oda içerisinde kilerüstü dolabının altında yer alan genellikle mutfak eşyası veya odun muhafaza edilen, zaman zaman da buzağı ve kuzuların barındı ̆̆ı dolap.

Kiler Odası: Kentte zemin katta hergil dolabının ve tel dolabın yerleştirildiği oda.

Kilerüstü Dolabı/Ekmek Dolabı: Kilerin üzerinde yer alan bir miktar mutfak malzemesinin ve yiyeceğin muhafaza edildiği dolap.

Kitleme: Kent merkezinde yı̆̆ma yapılardaki geçmelere verilen ad.

Koğuş Tahtası: Kaplamada veya iç bölüntüde kullanılan darabadan uzun kereste. Kalınlığı yaklaşık 2 santimdir.

Kol: Çardakta mısırların asılarak kurutulduğu çıtalar.

Korkuluk: Pencere önlerinde yer alan ahşap parmaklıklar.

Kovuk: Ocak nişi.

Kovuk Ağaç/Kubur Ağacı: Tuvalette meydana gelen pisliğin evin altında yer alan kuburluğa inmesini sağlayan ahşap oluk.

Kök Ağacı: Kelebe direklerinin oturtulduğu iki adet yatay ahşap eleman.

Kuburluk/Kenef Altı: Tuvaletin altında atıkların indiği alan. Burada ot ve yapraklarla karıştırılan tuvalet atıkları tarlalarda gübre olarak değerlendirilmiştir.

Kulluk/Gulluk/Güllük: Konutların zemin katında yer alan depo vazifesi de gören yaşanılmayan giriş mekanı.

Küfün Taşı: Ocağın yapımında kullanılan baltayla yonulabilecek kadar yumuşak, hafif ve gözenekli taş cinsi, küfeki taşı.

Lamba: Tavan döşemesi, taban döşemesi, iç duvarlar ve hergillerin yapımında kullanılan bir teknik.

Maktaya Çıkmak: İnşaata uygun ağaçların ormana gidilerek işaretlenmesi.

Mayalı Toprak: Çamur harcı yapmaya elverişli killi toprak.

Mertek: Mahyadan binanın dışına doğru uzatılan ağaç elemanlar.

Miri Orman: İnşaatta kullanılan ahşabın temin edildiği sahipsiz orman alanları.

Miyaz/Minyaz: Binanın temeli. Derinlik 50-100 cm arasında arazinin eğimine göre değişir. Temel duvarların oturacağı alanın genişliği ise $60-70 \mathrm{~cm}$. arasındadır.

Miyaz Taşı: Temele yerleştirilen iri (300-500 kg.) taşlar. Genellikle her evin altında 12 tane (çatmaların veya dikmelerin altında) olur. 
Miyaz Kütüğü/Temel Meşesi/Kötürüm Ağacı/Çindi Ağacı: Miyaz taşının üzerine yerleştirilen, evin yükünü temele aktaran ve genellikle meşeden elde edilen ahşap eleman. $25 \times 30 \mathrm{~cm}$. ebatlarındadır.

Ocak Kirişi/Ateş Ağacı: Zemin katla birinci kat arasında yer alan ve yalnızca ağır taş ocakların yüklerini taşımakla mükellef kalın ağaç kiriş. Ocak kirişleri $35-40 \mathrm{~cm}$. çapındadır.

Ocak Taşı: Taş ocaklarından elde edilen yapı taşı.

Ocaklık Yeri: Değirmenin inşa edilmesine müsait, suya yakın arazi.

Ocaklık Çıvı: Ocağın altında yer alan üç ayrı katmandan oluşan (en altta ahşap, ortada toprak üstte taş) döşeme.

\section{Oluklu Kiremit/Yerli Kiremit:}

Omuzluk/Boy Meșesi/Maha: Mahya. 10x5 ya da 12x5 cm. ebadındadır. Yükssekliği çatının eğimine göre değişir.

Öğmek: Çamur harcı ya da bağdadi sıvası yaparken materyali birbirine karıştırmak.

Öndül: Çatı kapatılırken ustalara bahşiş olarak getirilen havlu, kumaş, mintan gibi hediyelere verilen ad.

Öndül Ăgacı: Çatıda öndülün takıldığı uzun sırık.

Pabuç: Karkas yapılarda dikmelerin altına yerleştirilen ve temel vazifesi gören taş altyap1.

Pasak/Basak: Merdiven

Pasakdibi: Merdivenin önündeki boş alan.

Payanda/Ara Payanda/İğreti Payanda/Ayıbacağı: Karkas yapılarda direklerin esnemesini ve açılmasını önlemek amacıyla çapraz olarak uygulanan ahşap destekler.

Persek Taş: Ufak boyutlu taş.

Pervaz: Süpürgelik. Ahşap duvarların döşeme ile birleştiği alanda tahtaların ek yerlerini kapatmak için kullanılan yaklaşık $10 \mathrm{~cm}$ yüksekliğinde ve boyu odanın boyuna göre değişen ahşap şerit.

Sandık Başı Geçme: Yalnızca Ulus ilçesi, Aşağı Çerçi köyünde tespit edilebilen geçme tekniği. Evlerin zemin katında uygulanmıştır ve geçme biçimi kırlangıç kuyruğunu andırmaktadır.

Sargu: Karkas yapılarda dış veya iç duvar kaplaması.

Sergen: Odalarda ve epteslikte pencere seviyesinin üzerinde duvarlar boyunca uzayan ahşap raf.

Sergü/Sergi/Günlük//Yanlık/Gün Çağră̆ı/Çıkma: Evin güneş alan cephesinde yer alan kışa hazırlık faaliyetleri kapsamında bazı yiyeceklerin kenevir yaygılar üzerinde kurutulduğu ahşap çıkıntı, balkon. Kıbleye yani güneye çevrilir. 
Set/Peyke: Sedir. Odalarda veya çardakta pencereli duvarlar boyunca yerleştirilen, oturma ihtiyacını karşılayan ahşap eleman. $7 \mathrm{~cm}$. eninde ve $50 \mathrm{~cm}$. yüksekliğindedir.

Seyrek Doldurma: Ahşap çatkının arasının tuğla ile doldurulması yöntemi.

Sık Doldurma: Ahşap çatkının arasının ağaç artıkları ile düzenli bir şekilde doldurulmasına dayanan duvar tekniği. Ahşap dolma tekniği.

Söve: (1)Kemerli taş ocakların kilit taşı.(2)Kapıların iki yanındaki ahşap dikme söve dikmesi, söve dikmelerini birleştiren yatay eleman ise söve başlığı olarak adlandırılır. Söveler $5 \times 10 \mathrm{~cm}$ ebadında dikdörtgen kesitli ya da 10x10 cm ebadında kare kesitli elemanlardır.

Sübek/Kavile/Darak: Genellikle kullanılan hatılla aynı tür ağaçtan ya da yalnızca kiren (kızılcık) ağacından imal edilen $15-20 \mathrm{~cm}$. boyunda $2 \times 2 \mathrm{~cm}$. ebadında kare kesitli ağaç çivi. Hatılların birbirine tutturulması işlevini yerine getirir.

Sürme Pencere: Üstten ya da yandan sürülerek açılıp kapanan pencere.

Sürme Tahtası: Kiremit altı tahtası.

Şükranlık: Ev için kesilen kurban.

Tamak: Çift kanatlı dış kapılarda kullanılan ve ağaçtan imal edilen kilit sistemi.

Taşlık: Evin girişinde taş döşeli düz alan.

Temek: Ahır duvarlarında yer alan ışık ve havalandırma ihtiyacını karşılayan, ayrıca ortamda biriken hayvan pisliğinin, kemre, dışarı atıldığı açıklık; camsız ahır penceresi.

Teraziye Almak: Eğimli arazi üzerinde inşa edilen yapılarda binanın tabanının temel duvarları vasıtasıyla düzgünleştirilmesi.

Üveyik Kanadı/Eveyik Kanadı: Yalı baskısı. Binaların yağmura ve kara yoğun olarak maruz kaldıkları cephelerinde uygulanan bir tekniktir. Kent kökenli olup kırsal kesimde tespit edilen uygulamaları çok kaba ve basittir. Kaplama tahtaları birbirleri üzerine binecek şekilde çakılır, böylece yüzeye düşen suya karşı sızdırmaz bir cephe kaplaması oluşturulur. Kaplama sırasında üveyik (kumru) kuşunun kanadına benzer bir netice oluştuğu için yerel olarak bu isimle anılmaktadir.

Vakit Kesimi: İnşaatta kullanılacak ağaçların cinine göre değişen zaman dilimleri içerisinde kesiminin gerçekleştirilmesi.

Yangın Bacası/Yangın Penceresi/Kızgınlık/Kuzgunluk Tepesi: Çatıdaki kiremitleri aktarmak ve muhtemel yangınları söndürmek amacıyla kullanılan açıklık. Ayrıca bu açıklıktan çatı arasına ve oradan da çardağa 1şık vurur. Bu nedenle güne karşı yani güneye bakar.

Yaşmak: Ocağın ön yüzündeki taş kemer ya da onun yerini tutan ahşap eleman.

Yollama/Meşe Yollaması/Aykuru Ağaç/Bağ Ağacı: Karkas yapılarda temel taşlarının üzerine yerleştirilen ve birbirlerine geçmelerle sabitlenen büyük ağaç hatıllar.

Yonmak: Ahşabı ya da taşı inşaatta kullanılabilecek hale getirmek. 
Zar: Tavan kaplamasi.

\section{KAYNAKLAR}

Abdulkadiroğlu, Abdülkerim (1987), "Bartın ve Çevresinde Dini-Manevi Halk İnançları", Türk Folklorundan Derlemeler 1987, Ankara: Kültür ve Turizm Bakanlığı Yayınları. Yayınları.

Acıpayamlı, Orhan, (1976), Zanaat Terimleri Sözlüğü, Ankara: Türk Dil Kurumu

Akdemir, Zafer-Keskin, Metin (1993), "Bartın Evleri”, Arkitekt Dergisi, 11 (408), 8893.

Alga, Rabia (2005), Yaşam Döngüsüne Bağlı Olarak Konut Tasarımını Etkileyen Faktörler, Yüksek Lisans Tezi, İstanbul: İTÜ Fen Bilimleri Enstitüsü.

Alsaç, Üstün (1993), Türk Kent Düzenlemesi ve Konut Mimarlığı, İstanbul: İletişim Yayınları

Anonim (1998), Cumhuriyetimizin 75. Yılında Bartın, Bartın: İl Özel İdare Müdürlüğü Yayınları

Anonim (1992), Sosyo-Kültürel Değişme Sürecinde Türk Ailesi, Ankara: Aile Araştırma Kurumu Yayınları. San.Aş.

Aran, Kemal (2000), Barınaktan Öte. Anadolu Kır Yapıları, Ankara: Tepe İnşaat

Asatekin, G. (1994), “Anadolu'daki Geleneksel Konut Mimarisinin Biçimlenmesinde Aile-Konut Karşılıklı İlişkilerinin Rolü” Kent Planlama, Politik, Sanat. Tarık Okyay Anısına Yazılar, Ankara: ODTÜ Mimarlık Fakültesi Yayınları, 65-87.

Aşçıŏlu, E. (1970), İktisadi ve Sosyal Yönleriyle Bartın, Bartın Ticaret ve Sanayi Odası Yayını, İstanbul: Ahmet Sarı Matbaası.

Aşçıoğlu, Erkan (1984), Bartın, Bartın: Ticaret ve Sanayi Odası Yayınları

Atukeren, İhsan (1939), Cumhuriyetin 15.Yılında Bartın Çevresi ve Ortaokulu, İstanbul: Ülkü Basımevi

Ayvazoğlu, B., (1992), “İnsan, Ev, Çevre”, Sosyo-Kültürel Değişme Sürecinde Türk Ailesi. Ankara: Başbakanlık Aile Araştırma Kurumu Yayınları, cilt 2: 770-785.

Ayverdi, Ekrem Hakkı (1966), Osmanlı Mimarisinin İlk Devri, İstanbul: Fetih Cemiyeti Yayınları.

Bektaş, Cengiz (2001), Halk Yapı Sanatı, İstanbul: Literatür Yayıncılık

Berkel, A. (1970), Ağaç Malzeme Teknolojisi, İstanbul: İstanbul Üniversitesi Orman Fakültesi Yayınları.

Bozkurt, A.Y. (1982), Ahşap Teknolojisi, İstanbul: İstanbul Üniversitesi Orman Fakültesi Yayınları.

Cansever, Turgut (2009), İslam'da Şehir ve Mimari, İstanbul: Timaş Yayınları. 
Ceyhan, Gökçe (2002), Türkiye'de Konut İç Mekanları Ve Donatılarında Değişim Ve Süreklilik, Yüksek Lisans Tezi, İstanbul: İstanbul Teknik Üniversitesi.

Çelik-Deniz-Açıksöz, Sebahat (2008), “Tarihi Kentlerde Kent Estetiği Kaygısı: Bartın Örneği”, Bartın Orman Fakültesi Dergisi, 10 (14), 57-65.

Çelikyay, Selda (2000), "Bartın Evlerinde Ahşap ve Mimari”, Geleneksel ve Çağdaş Mimarlıkta Ahşap Panel ve Forumu, Ankara: TMMOB Yayınları

Çetinor, Bülent (1989), “Batı Karadeniz ve Evleri”, İlgi, s. 59

Çilsüleymanoğlu, Selahattin (Haz.) (1996), Bartın Halk Kültürü, Ankara: Türk Tarih Kurumu Yayınları.

Dağıstanlı, Kader (2007), Mimarsız Mimarlık ve Bingöl, Kiğı, Alagöz Köyü Üzerine Bir İnceleme, İstanbul: Yıldız Teknik Üniversitesi Fen Bilimleri Enstitüsü Yüksek Lisans Tezi.

Davulcu, Mahmut, (2009), "Sakarya Yöresi Kırsal Yerleşmelerinde Konut Mimarisi ve Ustalık Geleneği Üzerine Bir İnceleme”, Kastamonu Üniversitesi Kastamonu Eğitim Dergisi, 17(2), 687-706.

Denel, Serim (1977), "Halk Mimarisi Üzerinde Gözlem ve İncelemelerde İzlenebilecek Yöntem ve Yakındana İlgili Diğer Dallar İle Olan Bağıntısı Üzerinde Görüşler”, Türkiye’ de Toplumsal Bilim Araştırmalarında Yaklaşımlar ve Yöntemler, Ankara: ODTU THBT Yayınları.

Dikeçliğil, B. (1995), “Türk Toplumunda Aile Tipleri”, Cumhuriyet Dönemi Türkiye Ansiklopedisi-Yüzyıl Biterken, İstanbul: İletişim Yayınları.

Doğanay, Hayati (1994), Türkiye Beşeri Coğrafyası, Ankara: Gazi Büro Kitabevi. Yayınları.

Eldem, Sedat Hakkı (1968), Türk Evi Plan Tipleri, İstanbul: İTÜ Mimarlık Fakültesi

Eldem, Sedat Hakkı (1984-86-87), Türk Evi, I-II-III, İstanbul: TAÇ Yayınları.

Elmacı, Ergül (2007), Bir Liman Kenti Bartın (1830-1923), Yüksek Lisans Tezi, İstanbul: Marmara Üniversitesi.

Erder, N. (1984), Türkiye'de Ailenin Değişimi: Toplumbilimsel İncelemeler, Ankara: Türk Sosyal Bilimler Derneği Yayınları.

Eyce, Berrin (2000), “Tarihten Günümüze Türk Aile Yapısı”, Selçuk Üniversitesi Sosyal Bilimler Meslek Yüksekokulu Dergisi, 4, 223-243.

Geray, Cevat (1985), “Türkiye’de Köysel Yerleşme Düzeni”, Köy Sosyolojisi Okuma Kitabı (Der.Oğuz Arı), İstanbul:Boğaziçi Üniversitesi Yayınevi.

Göğebakan, Yüksel (2015), “Karakteristik Bir Değer Olan Geleneksel Türk Evi’nin Oluşumunu Belirleyen Unsurlar ve Bu Evlerin Genel Özellikleri”, İnönü Üniversitesi Kültür ve Sanat Dergisi, 1 (1), 41-55.

Gökçe, Birsen (1976), “Aile ve Aile Tipleri Üzerine Bir İnceleme”, Hacettepe Üniversitesi Beşeri Bilimler Dergisi, 8 (1-2), 46-67. 
Görmüş Çetinkale, Sevgi-Aşıksöz, Sebahat (2007), "Kentsel Peyzajda Geleneksel Dokunun Sürdürülebilirliği: Bartın Örneği”, Ankara Üniversitesi Ziraat Fakültesi Tarım Bilimleri Dergisi, 13 (2), 81-88.

Görmüş, Sevgi-Oğuz, Dicle (2013), "Kırsal Yerleşim ve Korunan Alan Arasındaki Etkileşimin Değerlendirilmesinde Peyzaj Karakter Analizinin Rolü: Kapısuyu Havzası Örneği”, Tarım Bilimleri Dergisi, 19, 310-322.

Günay, Reha (1999), Türk Ev Geleneği ve Safranbolu Evleri, İstanbul: Yap1-Endüstri Merkezi Yayınları.

Gür, S. Ö. (2000), Doğu Karadeniz Örneğinde Konut Kültürü, İstanbul: Yem Yayınları.

Hasol, Doğan (1990), Ansiklopedik Mimarlık Sözlüğü, İstanbul: Yap1 - Endüstri Merkezi Yayınları.

Kafesçioğlu, Ruhi (1955), Kuzey Batı Anadolu' da Ahşap Ev Yapıları, İstanbul: Pulhan Matbaası.

Kemik, C. (1988), Bartın Kentsel Değerler ve Sivil Mimarî Örnekleri, Yüksek Lisans Tezi, İstanbul: Yıldız Teknik Üniversitesi.

Keskiner, Cengiz-Yaylı, Ayşegül (2000), "Bartın Evleri”, Parthenios, 5(2).

Kır, İbrahim (2011), “Toplumsal Bir Kurum Olarak Ailenin İşlevleri”, Elektronik Sosyal Bilimler Dergisi, 10 (36), 381-404.

Kongar, Emre (1970), “Türkiye'de Aile: Yapısı, Evrimi ve Bürokratik Örgütlerle İlişkileri”, Amme İdaresi Dergisi, 3 (2), 58-83.

Köse, Abdullah (2005), "Türkiye'de Geleneksel Kırsal Konut Planlarında Göçebe Türk Kültürü İzleri”, Afyon Kocatepe Üniv. Sosyal Bilimler Dergisi, 7 (2), 165-200.

Kuban, D. (1982), “Türk Ev Geleneği Üzerine Gözlemler”, Türk ve İslam Sanatı Üzerine Denemeler, İstanbul: Arkeoloji ve Sanat Yayınları.

Küçükerman, Önder-Güner, Şemsi (1995), Anadolu Mirasında Türk Evleri, İstanbul: Kültür Bakanlığı Yayınları.

Merter, Feridun (1990), 1950-1988 Yılları Arasında Köy Ailesinde Meydana Gelen Değişmeler (Malatya Örneği), Ankara: Basbakanlık Aile Arastırma Kurumu Başkanlığı.

Naumann, Rudolf (1991), Eski Anadolu Mimarlı̆̆ı, Ankara: TTK Yayınları.

Oğuz, Burhan (2001), Türkiye Halkının Kültür Kökenleri C.III İnşa-IsıtmaAydınlatma Teknikleri, İstanbul: Anadolu Aydınlatma Vakfı Yayınları.

Ögel, Semra (1977), “Halk Mimarisi, Bazı Özellikleri ve Sorunları”, Türkiye’ de Toplumsal Bilim Araştırmalarında Yaklaşımlar ve Yöntemler, Ankara: ODTU THBT Yayınları.

Özen, Ramazan (2001), “İnşaat Malzemesi Olarak Ahşap: Avantaj ve Dezavantajları”, Ahşap Kültürü -Anadolu’nun Ahşap Evleri, Ankara: Kültür Bakanlığı Yayınları.

Özgüç, Nazmiye-Tümertekin, Erol (2006), Beşeri Coğrafya: İnsan, Kültür, Mekân, İstanbul: Çantay Kitabevi 
Özgüner, O. (1970), Köyde Mimari-Doğu Karadeniz, Ankara: ODTÜ Mimarlık Fakültesi Yayınları.

Rapoport, Amos (1969), House Form and Culture, Englewood Cliffs, New Jersey: Prentice-Hall

Saatçi, Suphi (1997), "Halk Mimarisinin Halk Bilimi Açısından Değerlendirilmesi”, V. Milletlerarası Türk Halk Kültürü Kongresi Maddi Kültür Seksiyon Bildirileri, Ankara: Kültür Bakanlığı Yayınları.

Samancıoğlu, Kemal (1942), İktisat ve Ticaret Bakımından Bartın, Ankara: Ticaret ve Sanayi Odası Yayınları.

Samancığlu, Kemal (1954), Bartın Belediyesi ve Tarihçesi, Bartın: Belediye Yayınları.

Sarı, Salih (2007), Bartın İli Tarım Coğrafyası, Yüksek Lisans Tezi, Sakarya: Sakarya Üniversitesi.

Sayın, Önal (1990), Aile Sosyolojisi Ailenin Toplumdaki Yeri, İzmir: Ege Üniversitesi Basımevi.

Seğmen, Celal (2006), Bartın İli Ekonomisinde Ormancılık Sektörünün Yeri ve Önemi, Yüksek Mühendislik Tezi, Bartın: Zonguldak Karaelmas Üniversitesi.

Sey, Yıldız (Ed.) (1996), Tarihten Günümüze Anadolu' da Konut ve Yerleşme, İstanbul: Tarih Vakfi Yayınları

Sözen, Metin-Eruzun, Cengiz 1996), Anadolu'da Ev ve İnsan, İstanbul: Emlak Bankası Yayınları.

Tansuğ, S., (1992), “Türk Ev Mimarisinin Değişme ve Gelişme Çizgisi”. SosyoKültürel Değişme Sürecinde Türk Ailesi, Ankara: Başbakanlık Aile Araştırma Kurumu Yayınları, cilt 2, 756-769.

Tanyeli, Uğur (1996), “Anadolu’da Bizans, Osmanlı Öncesi ve Osmanlı Dönemlerinde Yerleşme ve Barınma Düzeni”, Tarihten Günümüze Anadolu'da Konut ve Yerleşme, İstanbul: Türkiye Ekonomik ve Toplumsal Tarih Vakfi Yayınları.

Taş, Murat (2003), “Osmanlı’dan Günümüze Yapı Üretiminde Mimarlık Meslek Örgütlenmesinin Gelişimi”, Uludağ Üniversitesi Mühendislik-Mimarlık Fakültesi Dergisi, Cilt 8, Sayı 1.

Tekeli Ş. (1995), “Türk Toplumunda Aile Tipleri”, Cumhuriyet Dönemi Türkiye Ansiklopedisi-Yüzyıl Biterken, İstanbul: İletişim Yayınları.

Tezcan, Mahmut (2000), Türk Ailesi Antropolojisi, Ankara: İmge Kitabevi.

Timur, Serim (1972), Türkiye'de Aile Yapısı, Ankara: Hacettepe Üniversitesi Nüfus Etütleri Enstitüsü.

Tolun, Bedriye (1977), Yerleşme Coğrafyası (Kır Yerleşmeleri), İstanbul: İstanbul Üniversitesi Coğrafya Enstitüsü Yayınları.

Tuncel, M. (1992). "Bartın” Maddesi, Diyanet İslam Ansiklopedisi (DİA), V, İstanbul: Diyanet İşleri Başkanlığı, 87-90.

Tuncer, Orhan Cezmi (2002), Ankara Evleri, Ankara: Ankara Ticaret Odası Yayınları. 
Tunçdilek, N. (1967), Türkiye İskân Coğrafyası, Kır İskânı (Köy-Altı İskân Şekilleri), İstanbul: İstanbul Üniversitesi Edebiyat Fakültesi Yayınları.

Tunçdilek, Necdet (1986), Türkiye'de Yerleşmenin Evrimi, İstanbul: İstanbul Üniversitesi Coğrafya Enstitüsü Yayınları.

Tümertekin, E.-Özgüç, N. (2002), Beşeri Coğrafya: İnsan, Kültür, Mekân, İstanbul: Çantay Kitabevi.

Uzunarslan, H.Ş. (2002), Erken Cumhuriyet Dönemi Konutlarında Mekân ve Mobilya, Yüksek Lisans Tezi. İstanbul: MSÜ Fen Bilimleri Enstitüsü.

Yeler, Gülcan Minsolmaz (2005), Konut Mimarlığında Ekolojik ve Sosyo-Kültürel Etkenlerin Analizi, Yüksek Lisans Tezi, Edirne, Trakya Üniversitesi Fen Bilimleri Enstitüsü.

Yücel, Talip (1987), Türkiye Coğrafyası, Ankara: Türk Kültürünü Araştırma Enstitüsü Yayınları.

Zeylan, Pınar Kezban (2009), 19. Yüzyıl Sonrası Türkiye'de Toplumsal Değişimlerin Konut Mekanına Etkisi, Yüksek Lisans Tezi, İstanbul: Mimar Sinan Üniversitesi Güzel Sanatlar Üniversitesi Fen Bilimleri Enstitüsü.

http://www.bartin.gov.tr

http://bartin.kultur.gov.tr

Bartın İl Çevre Durum Raporu-2006 (http://www2.cedgm.gov.tr)

A.SANTUR - G.BALIKÇI - M.DAVULCU, Bartın Halk Mimarisi Alan Araştırması (17 - 30Eylül 2001), Kültür Bakanlığı Halk Kültürlerini Araştırma ve Geliştirme Genel Müdürlüğü Araştırma Raporu, Ankara 2001

\section{KTB-HALK KÜLTÜRÜ BİLGİ VE BELGE MERKEZİ:}

(B.2001.0173),(B.2001.0174)， (B.2001.0175)， (B.2001.0176)， (B.2001.0177), (B.2001.0178), (B.2001.0179), (B.2001.0180), (B.2001.0181), (B.2001.0182), (B.2001.0183), (B.2001.0184)， (B.2001.0185)，(YB.2001.0039)，(YB.2001.0053)， (BVB.2001.0039), (YB.2002.0075)

\begin{tabular}{|l|c|l|c|c|}
\hline \multicolumn{1}{|c|}{ ADI } & $\begin{array}{c}\text { D. } \\
\text { TARİI }\end{array}$ & \multicolumn{1}{|c|}{ DOĞUM YERİ } & MESLEĞí & $\begin{array}{c}\text { ÖĞRENIM } \\
\text { DURUMU }\end{array}$ \\
\hline Adil AÇIKGÖZ & 1932 & $\begin{array}{l}\text { Bartın - Ulus - Kumluca - Zafer } \\
\text { Köyü }\end{array}$ & $\begin{array}{c}\text { Yapı Ustası } \\
\text { Marangoz }\end{array}$ & Okuma yazması var \\
\hline $\begin{array}{l}\text { Billur } \\
\text { AĞARTAN }\end{array}$ & 1955 & Bartın - Kurucaşile - Uğurlu Köyü & Ev hanımı & Ortaokul \\
\hline $\begin{array}{l}\text { Fatma } \\
\text { AĞARTAN }\end{array}$ & 1928 & Bartın - Kurucaşile-Uğurlu Köyü & Ev hanımı & Okuma yazması var \\
\hline $\begin{array}{l}\text { Niyazi ALTAŞ } \\
\text { Ahmet Necati } \\
\text { ALTIPARMAK }\end{array}$ & 1916 & Bartın - Ulus - Eldeş Köyü & Çiftçi & Okuma yazması yok \\
\hline Hüseyin AY & 1930 & Bartın - Ulus - Yukarıdere Köyü & Yapı Ustası & Ortaokul ikinci \\
sınıftan terk.
\end{tabular}




\begin{tabular}{|c|c|c|c|c|}
\hline Mehmet AY & 1947 & Bartın - Ulus - Yukarıdere Köyü & Çiftçi & İlkokul \\
\hline Tamam AY & 1931 & $\begin{array}{l}\text { Kastamonu - Azdavay - Dizdarlı } \\
\text { Köyü(1948’ de Bartın Ulus } \\
\text { Yukarıdere köyüne gelin gelmiş) }\end{array}$ & Ev hanımı & Okuma yazması yok \\
\hline $\begin{array}{l}\text { Hüsamettin } \\
\text { BİLGİÇ }\end{array}$ & 1927 & Bartın - Kurucaşile - Şeyhler Köyü & $\begin{array}{l}\text { Yap1 Ustası } \\
\text { Marangoz }\end{array}$ & $\begin{array}{l}\text { İlkokul beşinci } \\
\text { sinıftan terk }\end{array}$ \\
\hline $\begin{array}{l}\text { Muzaffer } \\
\text { DEMİRBAŞ }\end{array}$ & 1937 & Bartın - Kozcağız - Özbaşı Köyü & Yap1 Ustas1 & Okuma yazmas1 var \\
\hline $\begin{array}{l}\text { Bekir } \\
\text { DEMIRTÜRK }\end{array}$ & 1924 & Bartın - Kurucaşile - Kömeç Köyü & Çiftçi & İlkokul \\
\hline $\begin{array}{l}\text { İsmail } \\
\text { DİŞTOSUN }\end{array}$ & 1934 & Bartın - Kozcağız - Özbaşı Köyü & Yap1 ustas1 & Okuma yazması yok \\
\hline Bülent ÖZALP & 1936 & Bartın - Ulus - Ovatekkeönü Köyü & Kayı ustası & İlkokul \\
\hline Yusuf SARIALP & 1923 & Bartın - Ulus - Eldeş Köyü & Yap1 Ustas1 & İlkokul \\
\hline Fatma SARIALP & 1922 & Bartın - Ulus - Eldeş Köyü & Ev hanımı & Okuma yazması yok \\
\hline Hayri SEVİM & 1935 & $\begin{array}{l}\text { Bartın - Kurucaşile - Kapısuyu } \\
\text { Köyü }\end{array}$ & Emekli & İlkokul \\
\hline Fatma TOPAL & 1928 & Bartın - Ulus - Aşağıçerçi Köyü & Ev hanımı & Okuma yazması yok \\
\hline $\begin{array}{l}\text { Yaşar } \\
\text { YOĞURTÇU }\end{array}$ & 1916 & Bartın - Merkez & Mimar & İlkokul \\
\hline
\end{tabular}

\section{ÇİZIMLER:}

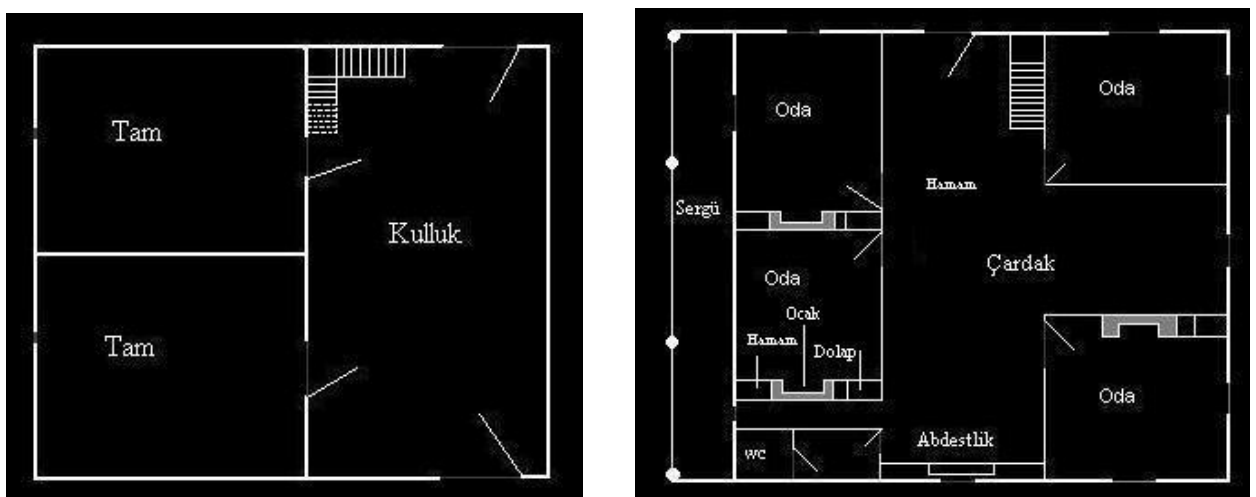

Çizim 1-2: Recep Topal Evi Zemin ve Birinci Kat Plan Krokisi-Ulus İlçesi Aşağıçerçi Köyü 

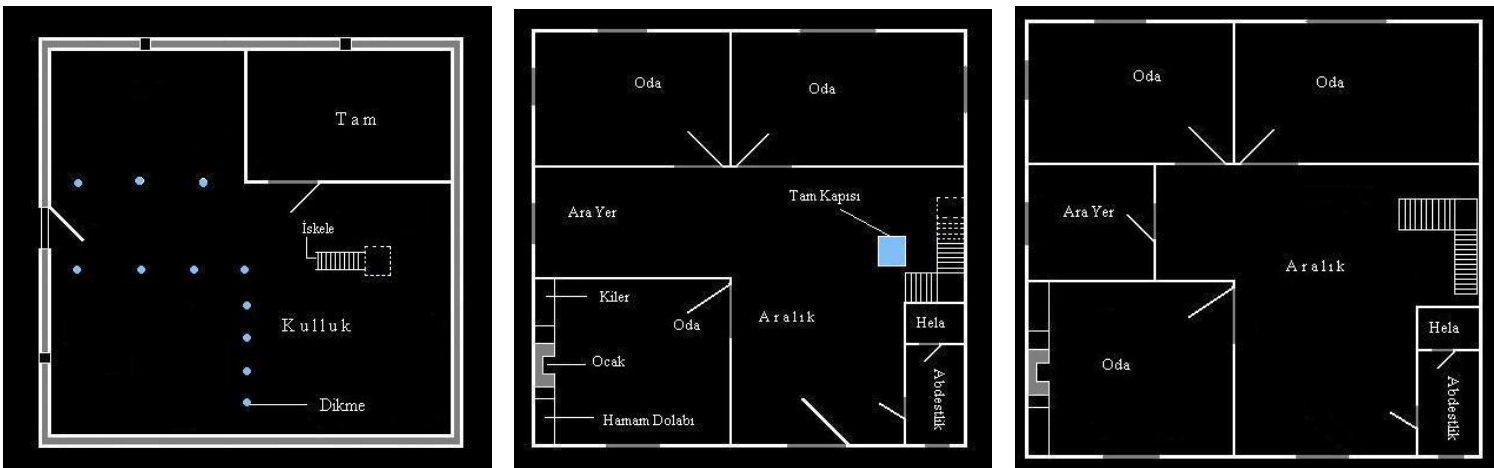

Çizim 3-4-5: Hayri Sevim Evi Zemin, Birinci ve İkinci Kat Plan Krokisi-Kurucaşile İlçesi Kapısuyu Köyü Yenimahalle
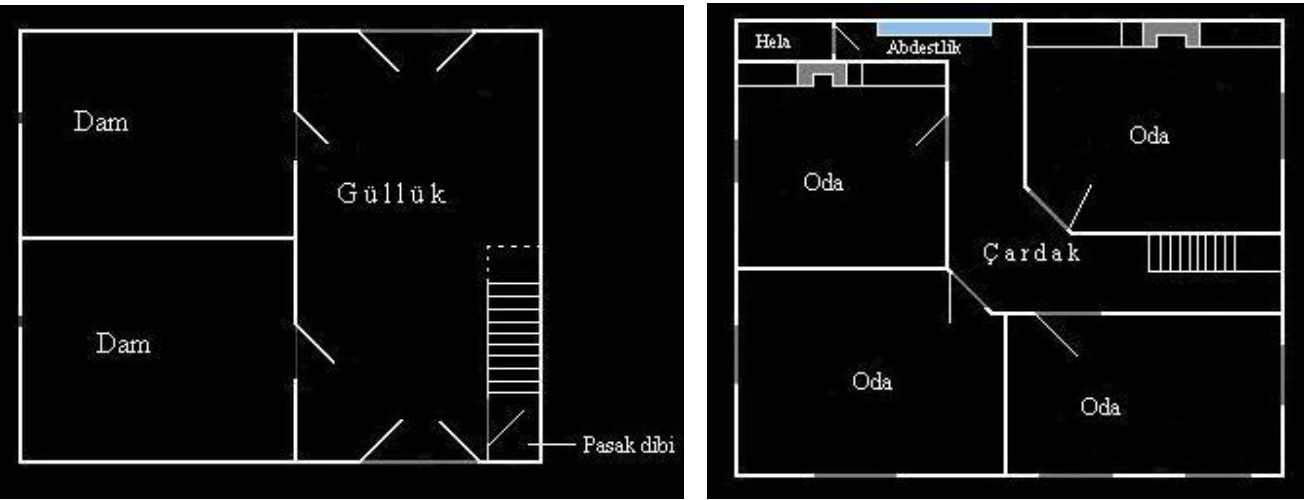

Çizim- 6-7: Ahmet Avcı Evi Zemin ve Birinci Kat Plan Krokisi-Kumluca Beldesi Zafer Köyü

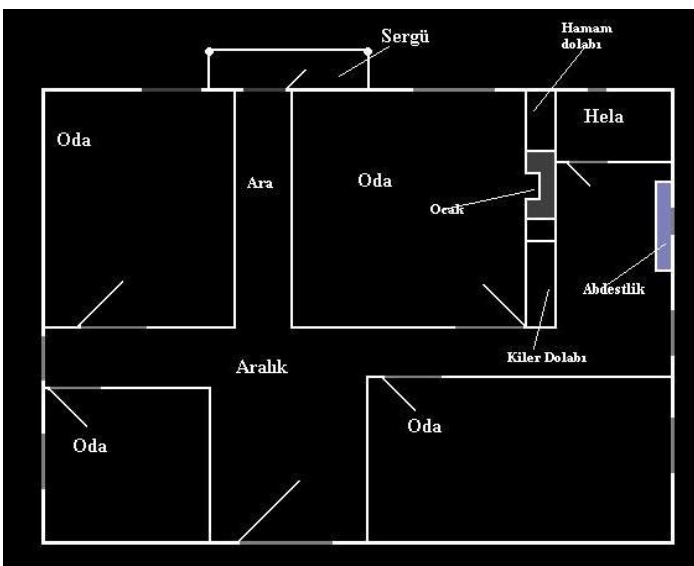

Çizim 8: Hayri Santur Evi Birinci Kat Plan Krokisi- Kurucaşile İlçesi Çayaltı Köyü

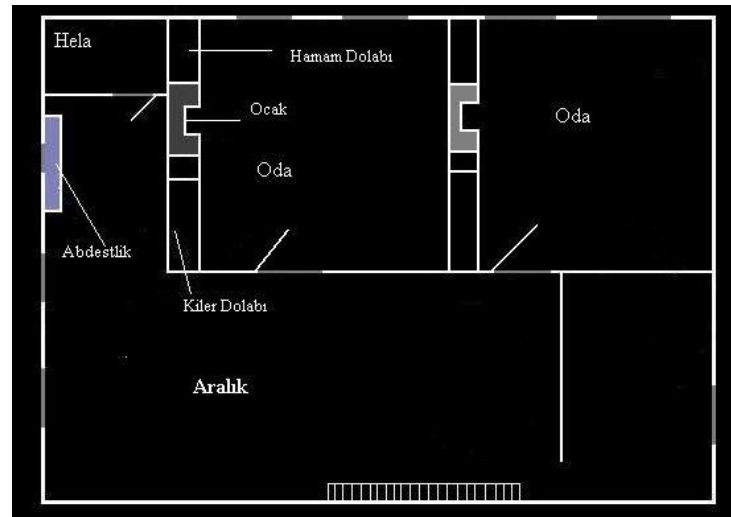

Çizim 9: Çavuş Kaptan Evi Birinci Kat Plan Krokisi- Kurucaşile İlçesi Kapısuyu Köyü

\section{TURUK}

International Language, Literature and Folklore Researches Journal 2016, Year 4, Issue 8

Issn: 2147-8872 


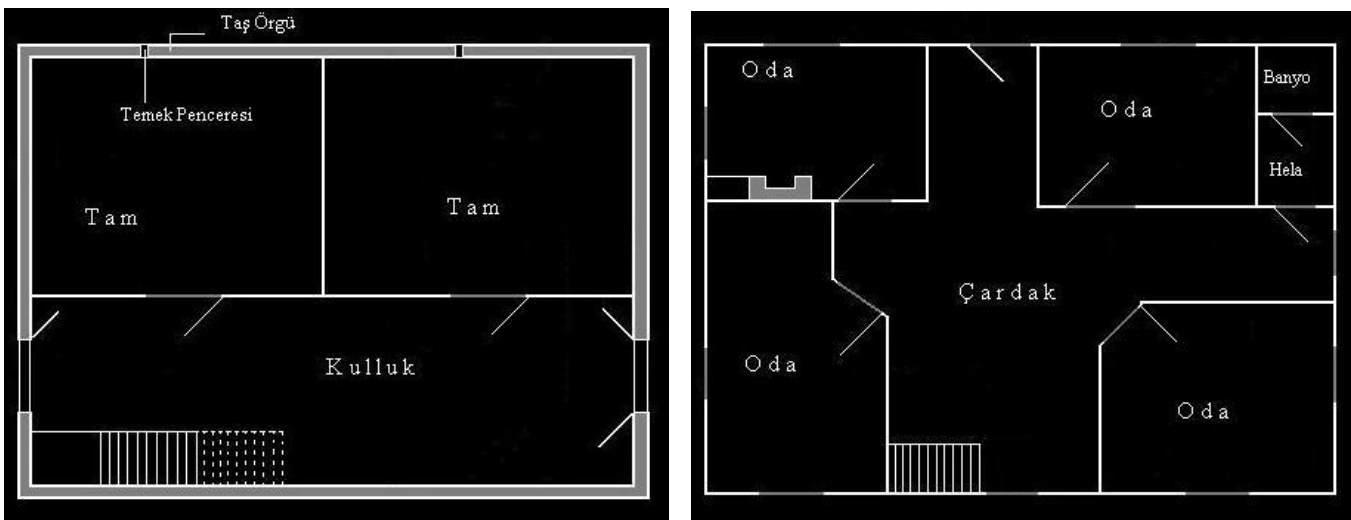

Çizim 10-11: Raşit Özaltan Evi Zemin Kat Plan Krokisi- Kozcağız Beldesi Mamak Köyü
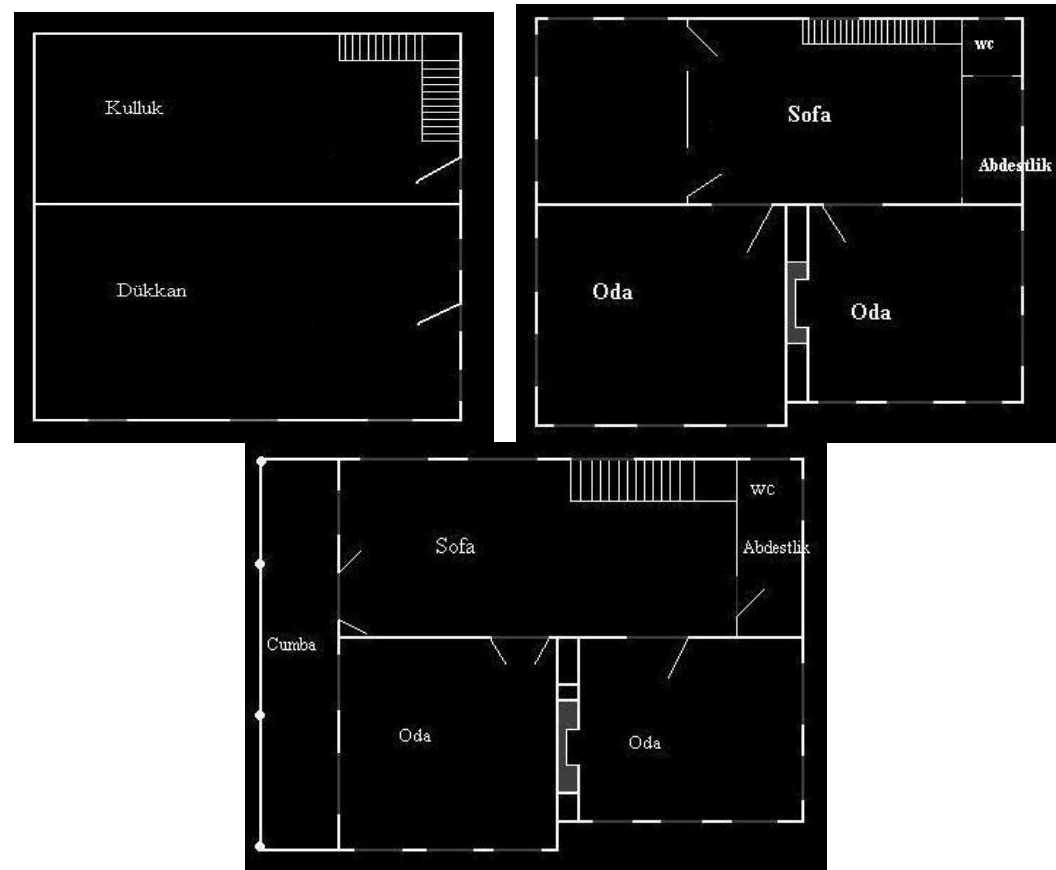

Çizim 12-13-14: Geleneksel Konut Zemin, Birinci ve İkinci Kat Plan Krokisi- Ulus İlçesi Merkez Cumhuriyet Meydanı

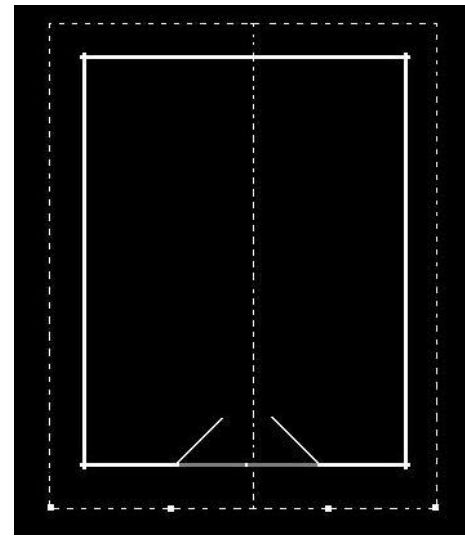

Çizim 15: Samanlık- Kozcağız Beldesi Mamak Köyü 


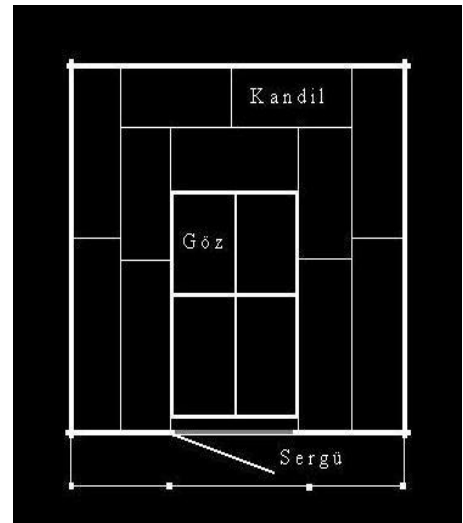

Çizim 16: Ahmet Avcı Ambarı Plan Krokisi- Ulus İlçesi Kumluca Beldesi Zafer Köyü Abdaloğlu Mahallesi
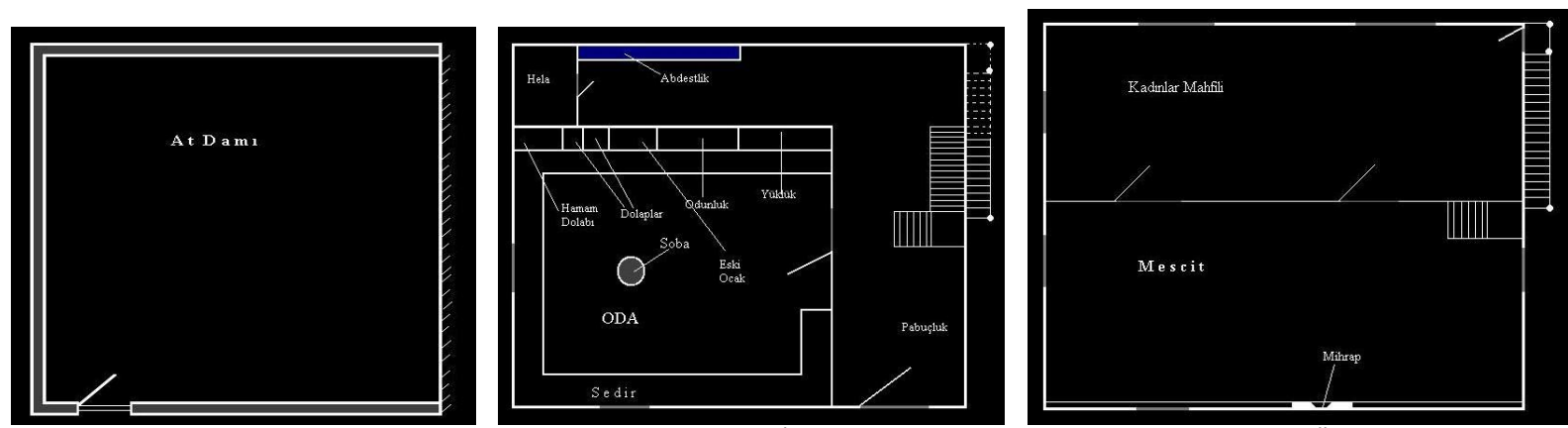

Çizim 17: Yukarımahalle Köyodası Zemin, Birinci ve İkinci Kat Plan Krokisi- Kozcağız Beldesi Özbaşı Köyü

FOTOĞRAFLAR:

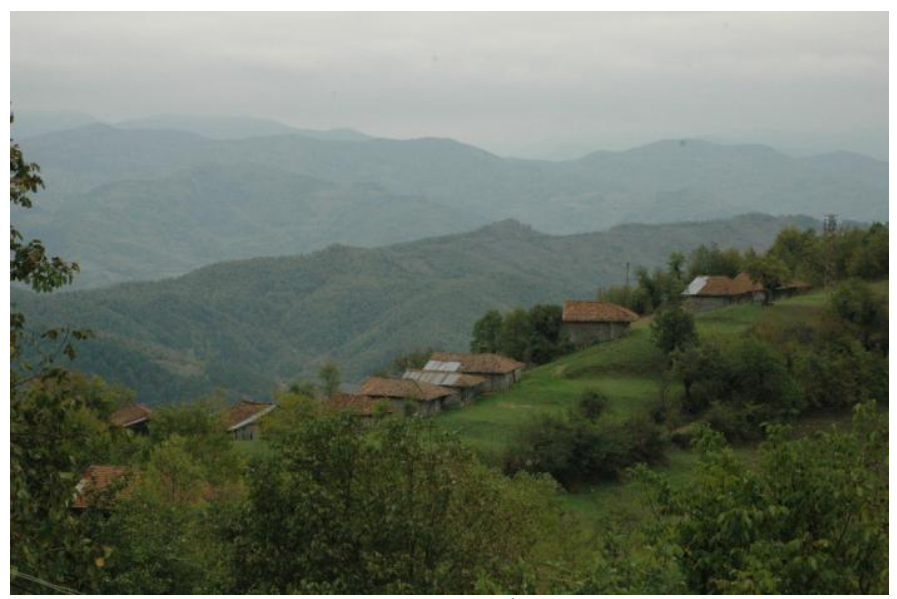

Fotoğraf 1: Yerleşim şekli (Ulus İlçesi Aşağıçerçi Köyü) 


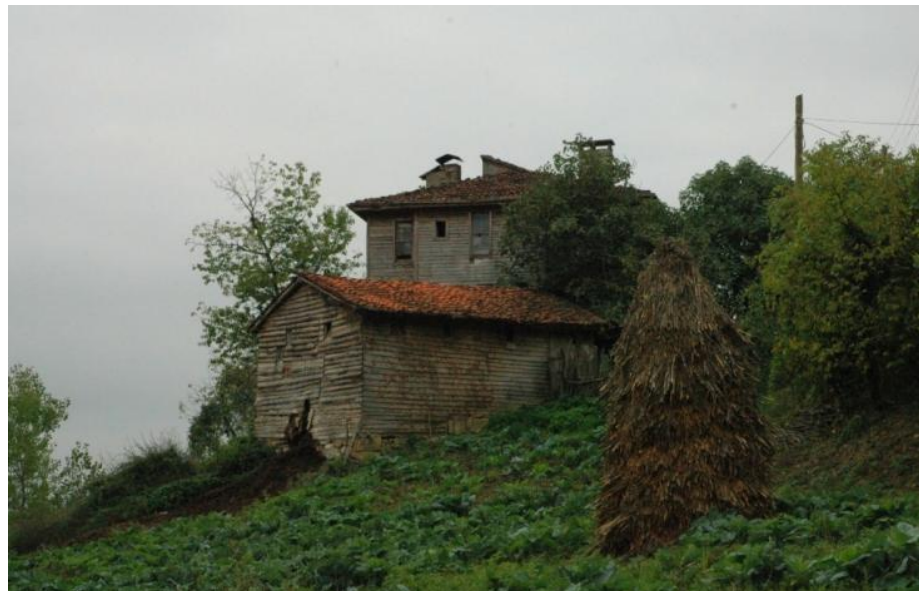

Fotoğraf 2: Müştemilatı ile birlikte geleneksel konut (Ulus İlçesi Aşă̆ıçerçi Köyü)

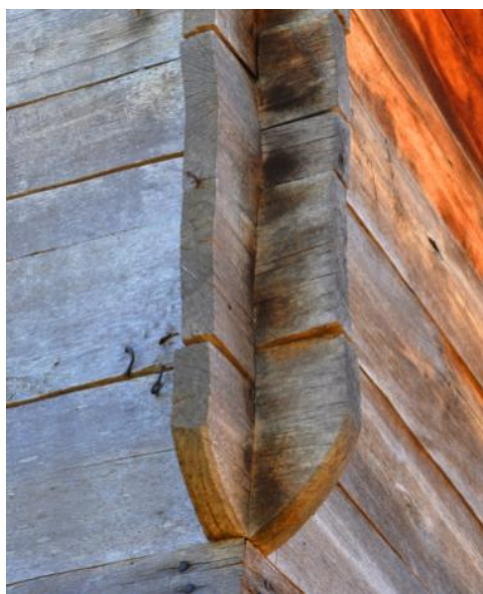

Fotoğraf 3: Ahşap yığma duvar tekniğ
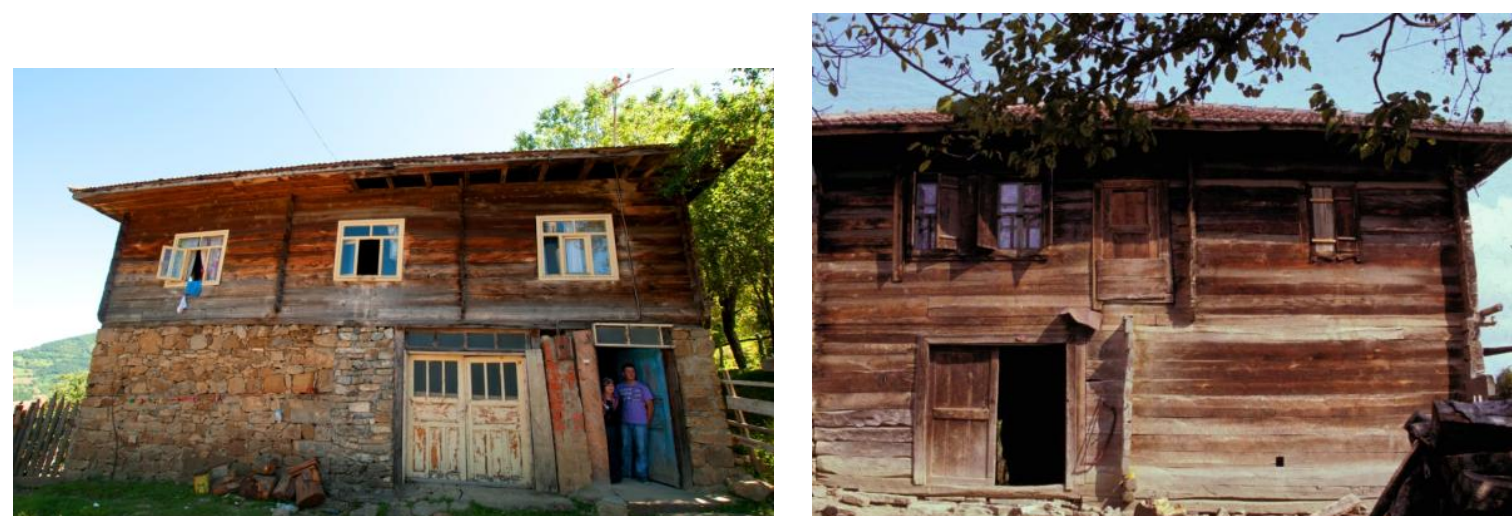

Fotoğraf 4: Ahşap yığma konut (Ulus İlçesi Özbaşı Köyü) Fotoğraf 5: Ahşap Yığma Konut(Kumluca Beldesi Zafer Köyü) 


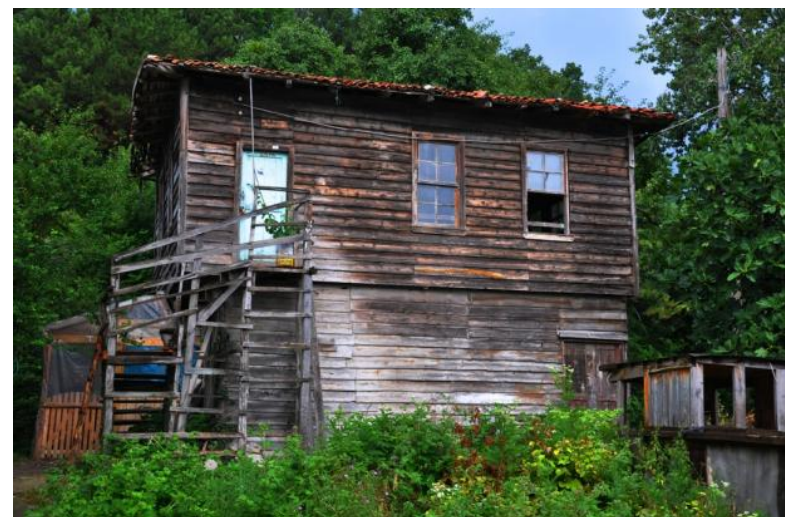

Fotoğraf 6: Ahşap karkas konut (Kurucaşile İlçesi Kapısuyu Köyü)
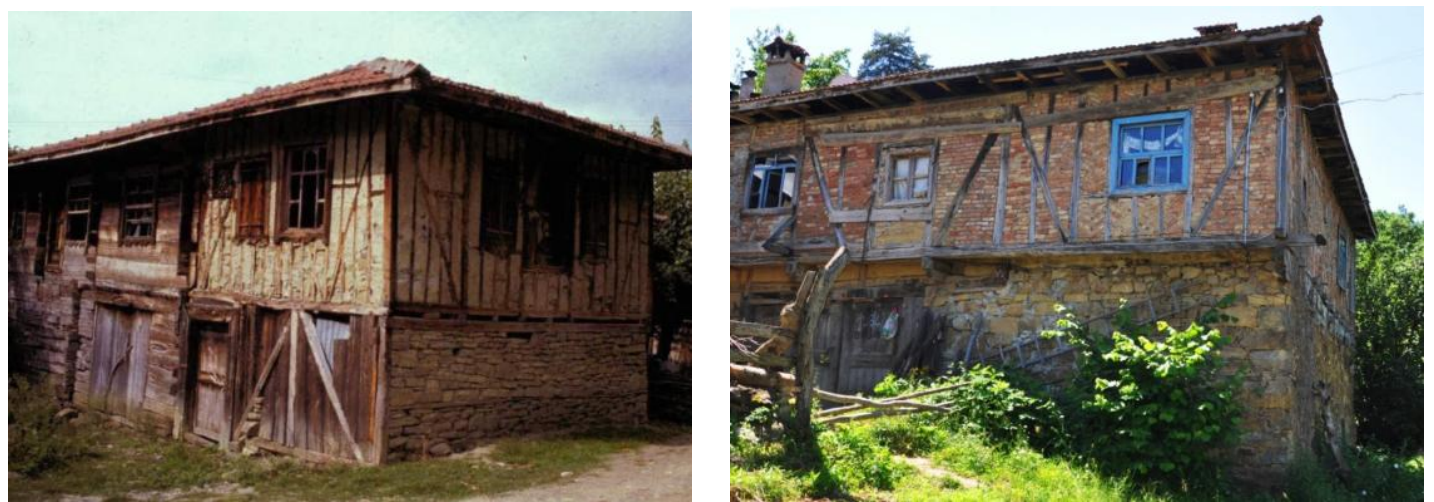

Fotoğraf 7: Doldurma tekniğinde konut (Kumluca Beldesi Zafer Köyü) Fotoğraf 8: Tuğla dolgulu ahşap karkas konut (Kozcağız Beldesi Merkez)

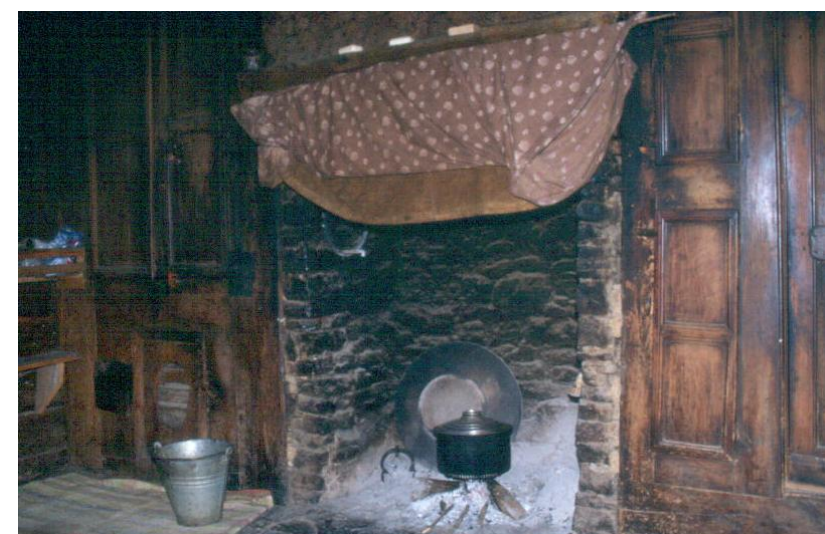

Fotoğraf 9: Oda İçerisinde Ocak ve Dolaplar (Ulus İlçesi Aşağı Çerçi Köyü Hasan Topal Evi) 


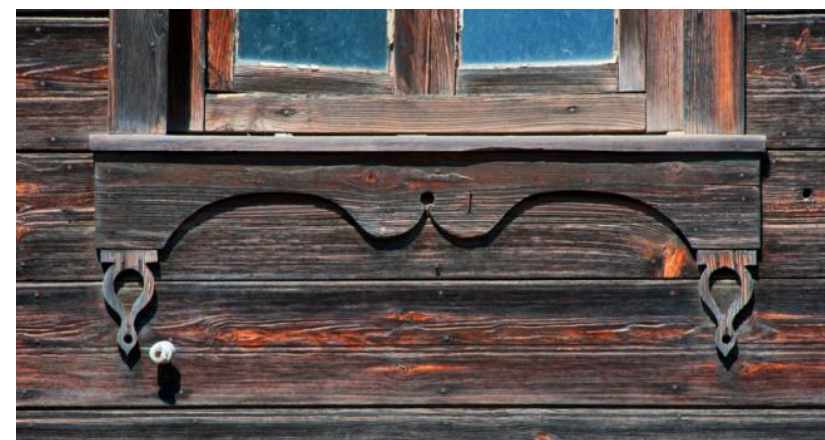

Fotoğraf 10: Pencere altında ahşap süsleme (Ulus İlçesi Merkez)

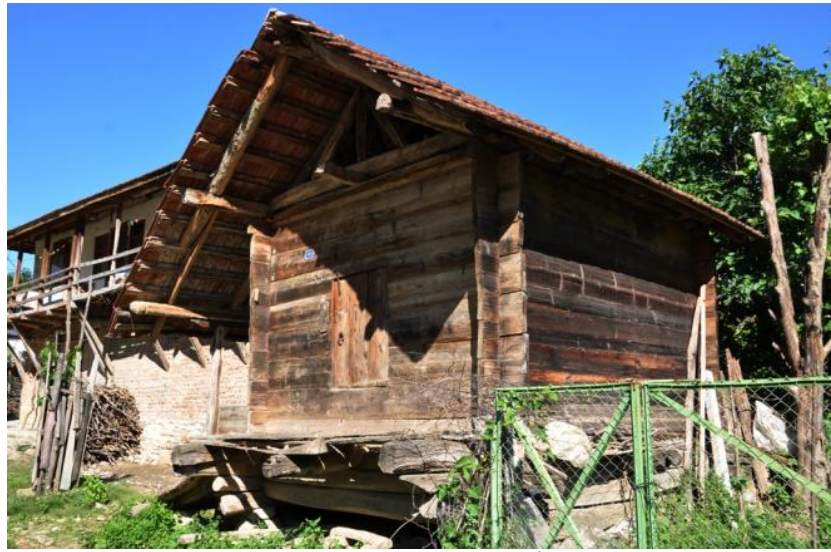

Fotoğraf 11: Ahşap yığma ambar (Ulus İlçesi Ulukaya Köyü)
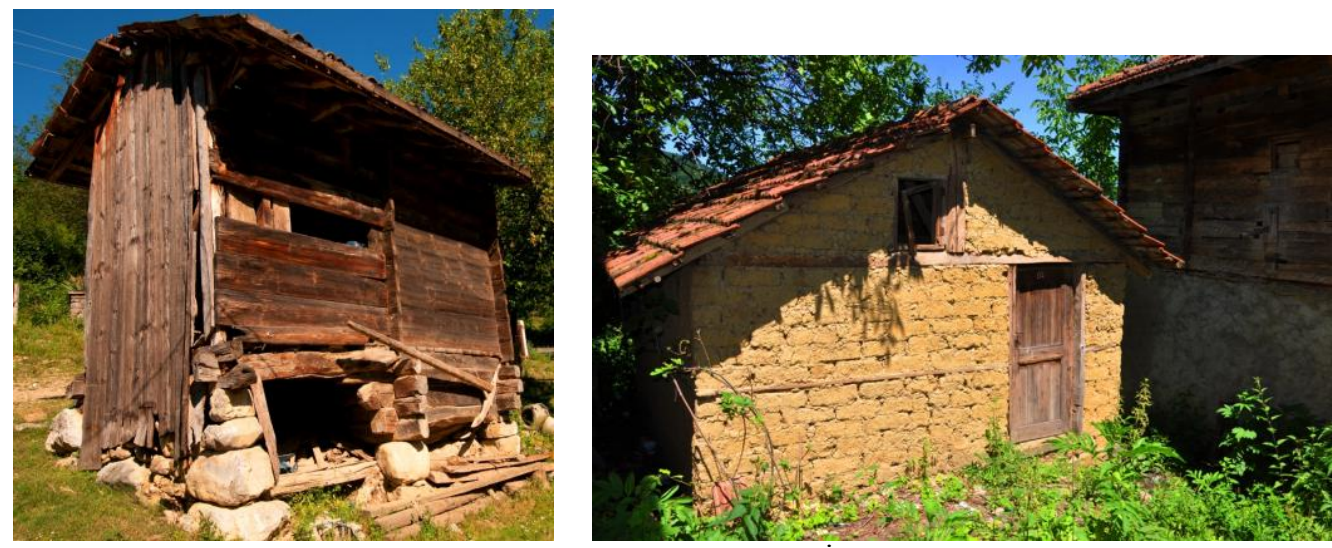

Fotoğraf 12: Ahşap yığma samanlık (Ulus İlçesi Eldeş Köyü)

Fotoğraf 13: Kerpiç samanlık (Ulus İlçesi Özbaşı Köyü) 

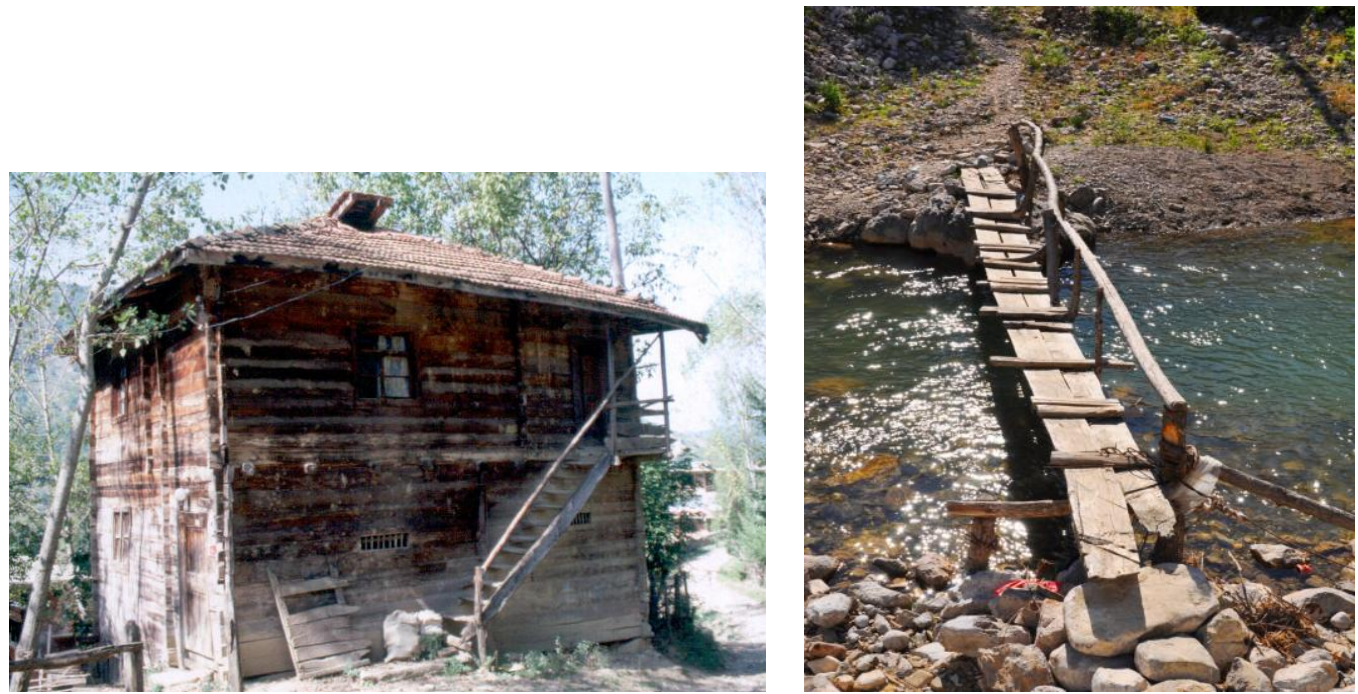

Fotoğraf 14: Yukarımahalle Köyodası (Kozcağız Beldesi Özbaşı Köyü) Fotoğraf 15: Köprü (Ulus İlçesi Ulukaya Köyü)
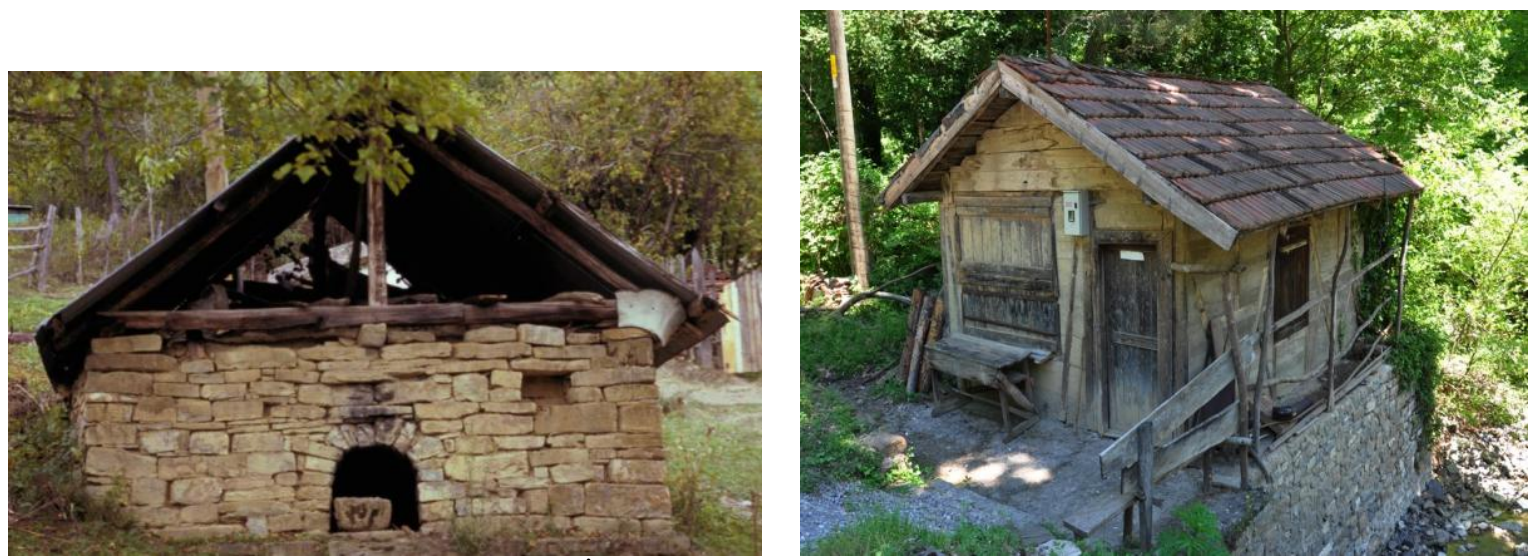

Fotoğraf 16: Taş firın (Ulus İlçesi Kumluca Beldesi Zafer Köyü Abdaloğlu Mahallesi) Fotoğraf 17: Su değirmeni (Ulus İlçesi Kalecik Köyü)
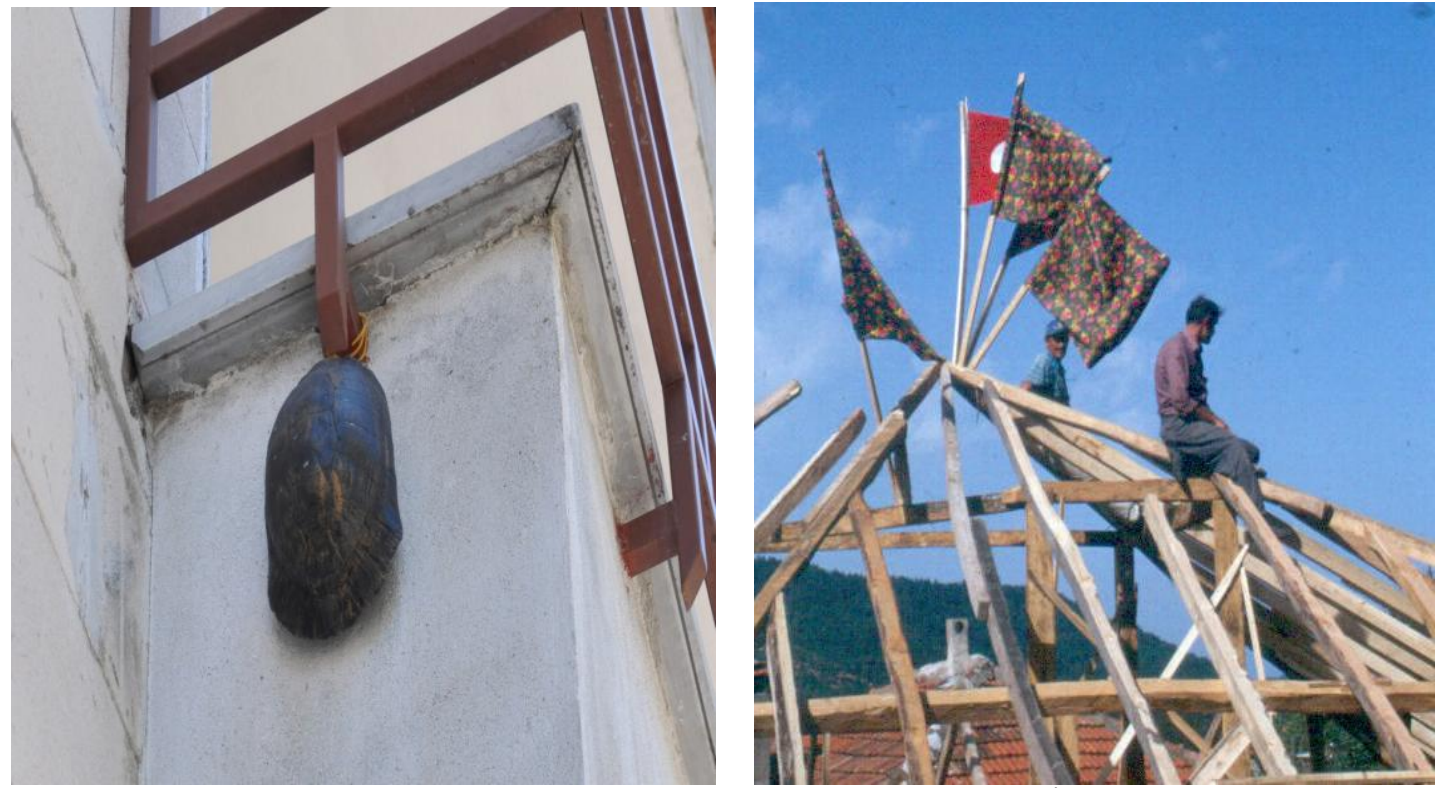

Fotoğraf 18: Nazarlık olarak asılmış olan kaplumbağa kabuğu (Merkez İlçe Uğurlar Köyü) Fotoğraf 19: Çatı kapatılırken bayrak asma uygulaması (Kurucaşile İlçesi Kömeç Köyü) 